\title{
Leaching Behavior of Glass Ceramic Nuclear Waste Forms
}

\author{
R. O. Lokken
}

November 1981

Prepared for the U.S. Department of Energy under Contract DE-AC06-76RLO 1830

Pacific Northwest Laboratory Operated for the U.S. Department of Energy by Battelle Memorial Institute 
NOTICE

This report was prepared as an account of work sponsored by the United States Covernment. Neither the United States nor the Department of Energy. nor any of their employees, nor any of their contractors. subconiractors. or their employees. makes any warranty, express or implied, or assumes any legal liability or responsibility for the accuracy. completeness or usefulness of any information. apparatus. product or process disclosed, or represents that its use would not infringe privately owned rights.

The views. opinions and conclusions contained in this report are those of the contractor and do not necessarily represent those of the United States Government or the United States Department of Energy.

\author{
PACIFIC NORTHWEST LABORATORY \\ operated by \\ BATTELLE \\ for the \\ UNITED STATES DEPARTMENT OF ENERGY \\ Under Contract DE-AC06-76RLO 7830
}
Printed in the united States of America
Available from

National Technical Information Service

United States Department of Commerce

5285 Port Royal Road

Springfield. Virginia 22151

Price: Printed Copy $\$$ $\therefore$ Microfiche $\$ 3.00$

NIIS

-Pages

Selling Price

$001-025$

026.050

54.00

$\$ 4.50$

$051.075 \quad \$ 5.25$

076-100 $\$ 5.00$

$101.125 \quad \$ 650$

126-150 57.25

$151.175 \quad \$ 8.00$

$176-200 \quad \$ 9.00$

$201.225 \quad 59.25$

$226.250 \quad \$ 9.50$

$251.275 \quad \$ 10.75$

$276 \cdot 300 \quad \$ 1100$ 
LEACHING BEHAVIOR OF GLASS CERAMIC NUCLEAR WASTE FORMS

R. O. Lokken

November 1981

Prepared for the U.S. Department of Energy under Contract DE-AC06-76RLO 1830

Pacific Northwest Laboratory Richland, Washington 99352 
. 


\section{SUMMARY}

Glass ceramic waste forms have been investigated as alternatives to borosilicate glasses for the immobilization of high-level radioactive waste at Pacific Northwest Laboratory (PNL). Three glass ceramic systems were investigated, including basalt, celsian, and fresnoite each containing $20 \mathrm{wt} \%$ simulated high-level waste calcine. The purpose of this study was to assess chemical durability of glass ceramic waste forms and to compare the results for the three glass ceramics with a reference borosilicate glass, 76-68.

The glass ceramic materials used in this study were prepared by melting base materials (basalt, celsian glass frit, fresnoite glass frit) with 20 wt\% simulated waste calcines. The calcines included PW-9, PW-4b-7, PW-8a-2, and two calcines used at Hahn Meitner Institute in Berlin in the development of celsian and fresnoite glass ceramics. The vitreous materials were annealed and subjected to a two-stage heat treatment for nucleation and crystal growth. The crystal phases formed, represented by idealized formulas, are:

- Basalt glass ceramic - augite ( $\mathrm{Ca}, \mathrm{Fe}, \mathrm{Mg}) \mathrm{SiO}_{3}$

- spinel $\mathrm{NiFe}_{2} \mathrm{O}_{4}$

- poweliite $(\mathrm{Ca}, \mathrm{Sr}) \mathrm{MoO}_{4}$

- Celsian glass ceramic - ceisian $\mathrm{BaAl}_{2} \mathrm{Si}_{2} \mathrm{O}_{8}$

- scheelite $\mathrm{BalloO}_{4}$

- pyrochtore (R.E.) $\mathrm{Ti}_{2} \mathrm{O}_{7}$

- Fresnoite glass ceramic - fresnoite $\mathrm{Ba}_{2} \mathrm{Ti}_{2} \mathrm{O}_{8}$

- scheelite $\mathrm{BaMoO}_{4}$

- perovskite Ca(R.E.,Ti)O 3

Static leach tests were performed on seven glass ceramic materials and one parent glass (before recrystallization) using procedures outlined by the Materials Characterization Center (MCC). Samples were leached at $90^{\circ} \mathrm{C}$ for 3 to 28 days in deionized water and silicate water. The results, expressed in 
normalized elemental mass loss, $\left(\mathrm{g} / \mathrm{m}^{2}\right)$, show comparable releases from celsian and fresnoite glass ceramics. Basalt glass ceramics demonstrated the lowest normalized elemental losses with a nominal release less than $2 \mathrm{~g} / \mathrm{m}^{2}$ when leached in polypropylene containers. The releases from basalt glass ceramics when leached in silicate water were nearly identical with those in deionized water. The overall leachability of celsian and fresnoite glass ceramics was improved when silicate water was used as the leachant. 


\section{CONTENTS}

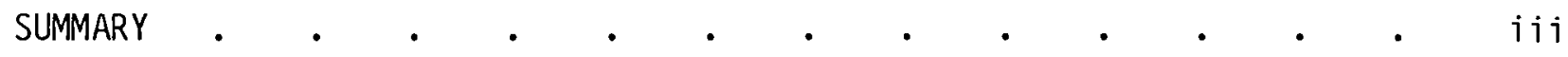

INTRODUCTION

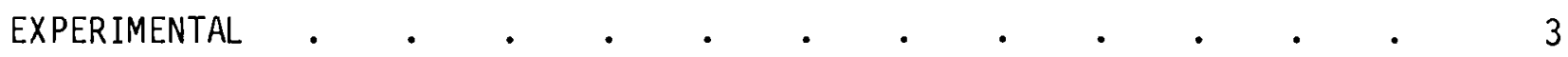

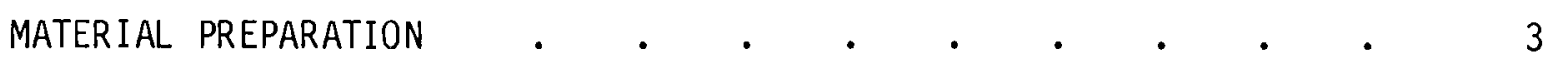

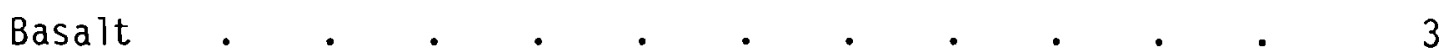

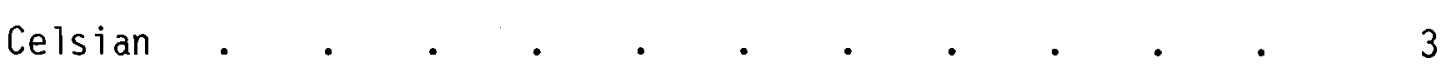

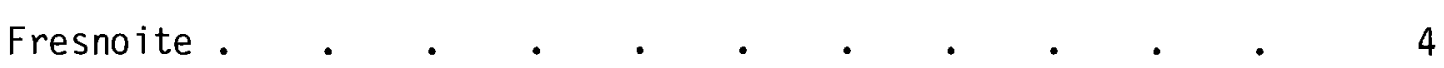

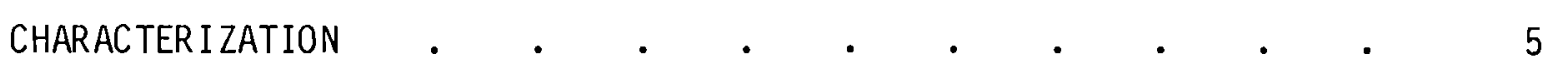

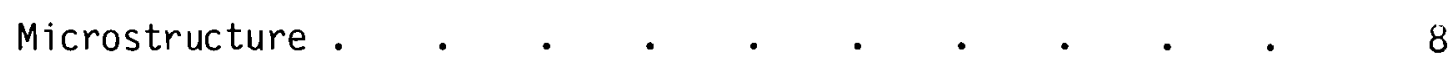

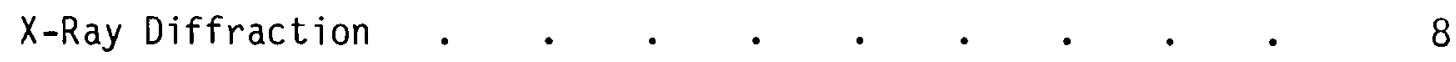

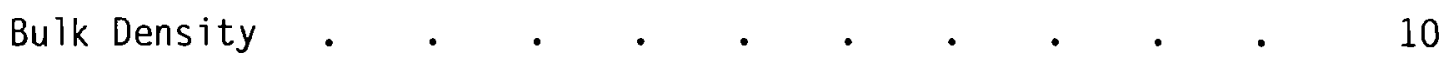

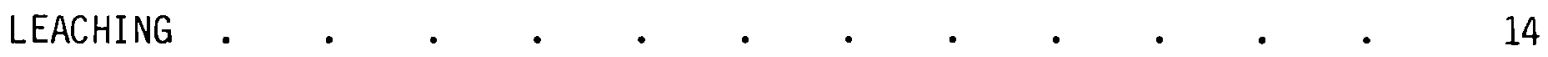

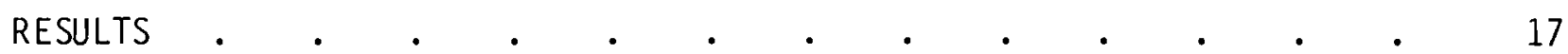

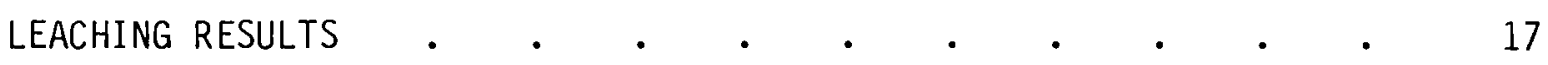

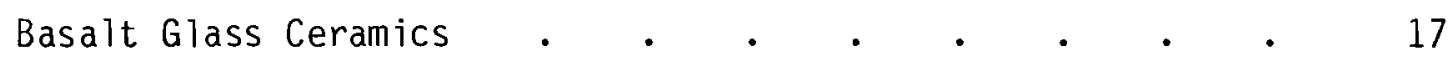

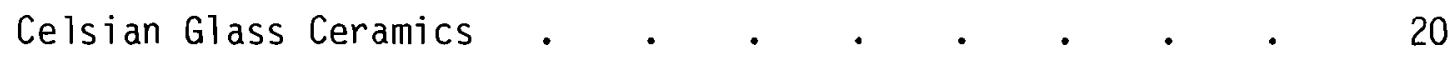

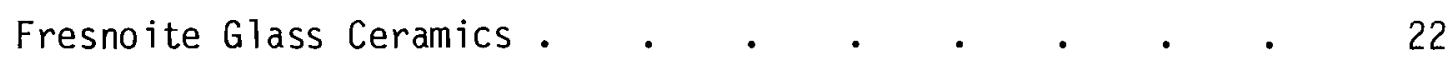

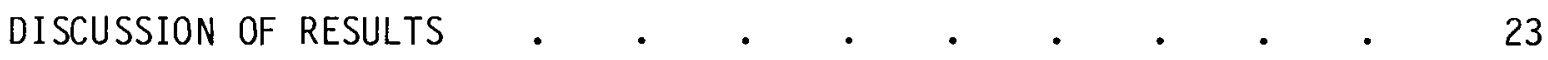

Effect of Leaching Time on Normalized Elemental Losses • $\quad 24$

Comparison of Leaching in Silicate Water and Deionized

Water . • • • • • • • • • • 32

Effect of Leach Container Material . $\quad$ • $\quad$ • $\quad$ • 35

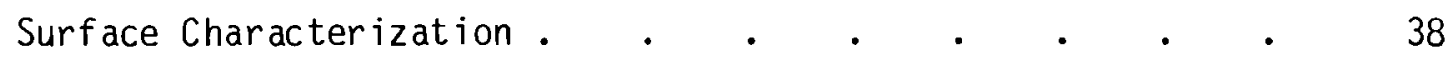




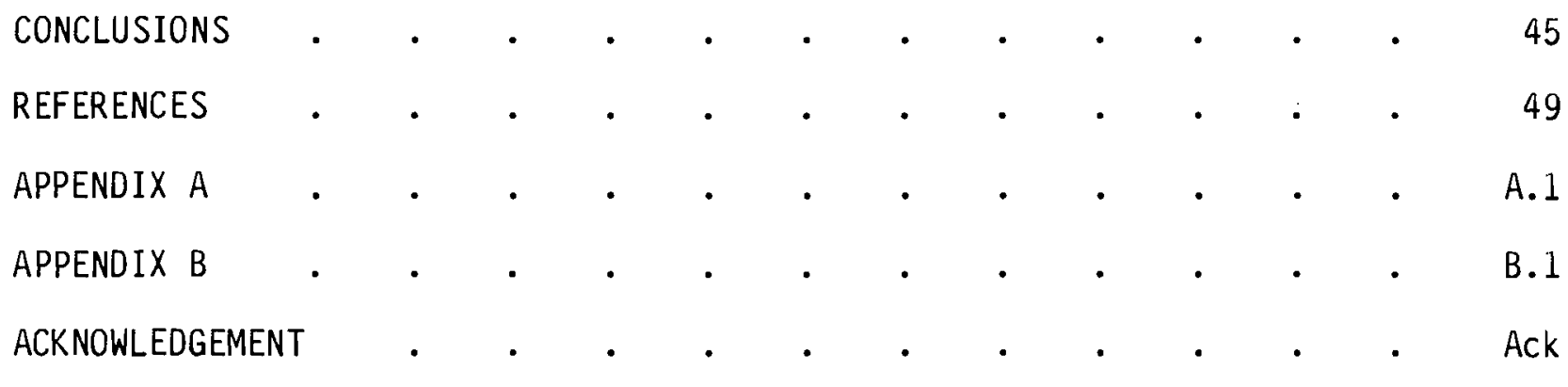




\section{FIGURES}

1 Micrographs of Basalt Glass Ceramics $\quad$. $\quad$. $\quad$. $\quad$. $\quad$. $\quad$. 9

2 Micrographs of Basalt Glass . . . . . . . . . . . . 10

3 Micrographs of Celsian Glass Ceramics . . . . . . . . . 11

4 Micrographs of Fresnoite Glass Ceramics . $\quad . \quad$. $\quad . \quad$ e $\quad$ e 12

5 Normalized Silicon Loss from Four Waste Forms as a Function of Leaching Time in Deionized Water at $90^{\circ} \mathrm{C} . \quad . \quad . \quad . \quad . \quad . \quad 25$

6 Normalized Strontium Loss from Four Waste Forms as a Function of Leaching Time in Deionized Water at $90^{\circ} \mathrm{C} . \quad . \quad . \quad . \quad . \quad$. 26

7 Normalized Cesium Loss from Four Waste Forms as a Function of Leaching Time in Deionized Water at $90^{\circ} \mathrm{C} . \quad . \quad . \quad . \quad . \quad 27$

8 Leachate $\mathrm{pH}$ as a Function of Leaching Time for Four Waste Forms After Leaching at $90^{\circ} \mathrm{C}$ in Deionized Water $\quad . \quad$. $\quad . \quad$. 29

9 Comparison of Normalized Barium Release from Glass Ceramics After Leaching for 28 Days at $90^{\circ} \mathrm{C}$ in Deionized Water . . .

10 Comparison of Normalized Silicon Release from Glass Ceramics After Leaching for 28 Days at $90^{\circ} \mathrm{C}$ in Deionized Water . . . 30

11 Comparison of Normalized Molybdenum Release from Glass Ceramics After Leaching for 28 Days at $90^{\circ} \mathrm{C}$ in Deionized Water . . .

12 Comparison of Normalized Strontium Release from Glass Ceramics After Leaching for 28 Days at $90^{\circ} \mathrm{C}$ in Deionized Water . . .

13 Comparison of Normalized Cesium Release from Glass Ceramics After Leaching for 28 Days at $90^{\circ} \mathrm{C}$ in Deionized Water . . .

14 Comparison of Normalized Molybdenum Release After Leaching in Deionized and Silicate Water . . . . . . .

15 Comparison of Normalized Strontium Release After Leaching in Deionized and Silicate Water . . . . . . . .

16 Comparison of Normalized Cesium Release After Leaching in Deionized and Silicate Water .......

17 Leachate $\mathrm{pH}$ as a Function of Leaching Time for Three Materials Leached in Deionized Water at $90^{\circ} \mathrm{C}$ in Polypropylene and Teflon Containers. 
18 Comparison of Normalized Elemental Losses from Three Materials Leached for 28 Days at $90^{\circ} \mathrm{C}$ in Deionized Water in Polyropylene and Teflon Containers

19 SEM Micrographs of BG-8 Surfaces Before and After Leaching in Deionized Water at $90^{\circ} \mathrm{C}$ for 28 Days. . . . . .

20 SEM Micrographs of BGC-8 Surfaces Before and After Leaching in Deionized and Silicate Water at $90^{\circ} \mathrm{C}$ for 28 Days . . . 40

21 SEM Micrographs of CGC-HMI Surfaces Before and After Leaching in Deionized Water at $90^{\circ} \mathrm{C}$ for 28 Days . . . . . . 42

22 SEM Micrographs of FGC-M4 Surfaces Before and After Leaching in Deionized Water at $90^{\circ} \mathrm{C}$ for 28 Days... . . .

23 Comparison of Normalized Elemental Releases from 76-68 Waste Glass with Those from Four Materials from This Study . . . .

A.1 X-Ray Diffraction Pattern of Basalt Glass Ceramic Containing 20 wt\% PW-9 Calcine. . . . . . . . . . A.1

A.2 X-Ray Diffraction Pattern of Basalt Glass Ceramic Containing 20 wt\% PW-4b-7 Calcine . . . . . . . . . A.2

A.3 X-Ray Diffraction Pattern of Basalt Glass Ceramic Containing 20 wt\% PW-8a-2 Calcine . . . . . . . . . A.3

A.4 X-Ray Diffraction Pattern of Basalt Glass Containing 20 wt\% PW-8a-2 Calcine. . . . . . . . . . . A.4

A.5 X-Ray Diffraction Pattern of Celsian Glass Ceramic Containing 20 wt\% PW-9 Calcine. . . . . . . . . . A.5

A. 6 X-Ray Diffraction Pattern of Celsian Glass Ceramic Containing 20 wt\% HMI Calcine $. \quad . \quad . \quad . \quad . \quad . \quad . \quad$.

A.7 X-Ray Diffraction Pattern of Fresnoite Glass Ceramic Containing 20 wt\% PW-9 Calcine.

A.8 X-Ray Diffraction Pattern of Fresnoite Glass Ceramic Containing 20 wt\% Modified PW-4b-7 Calcine 
$\underline{\text { TABLES }}$

1 Oxide Composition of Base Materials for Basalt, Celsian, and Fresnoite Glass Ceramics . . . . . . . . .

2 Nominal and Analyzed Composition of Glass Ceramic Waste Forms, Wt\%

3 Crystalline Phase Yield in Glass Ceramics . . . . . 13

4 Densities of Glass Ceramic Waste Forms . . . . . . 13

5 Normalized Elemental Losses $\left(\mathrm{NL}_{i}\right)$ for BGC-9 Leached at $90^{\circ} \mathrm{C}$. 18

6 Normalized Elemental Losses $\left(\mathrm{NL}_{i}\right)$ for $\mathrm{BGC}-4$ Leached at $90^{\circ} \mathrm{C} \quad$. 18

7 Normalized Elemental Losses $\left(\mathrm{NL}_{i}\right)$ for BGC-8 Leached at $90^{\circ} \mathrm{C} \quad$. 19

8 Normalized Elemental Losses $\left(\mathrm{NL}_{j}\right)$ for BG-8 Leached at $90^{\circ} \mathrm{C} \quad$. $\quad 19$

9 Normalized Elemental Losses $\left(\mathrm{NL}_{j}\right)$ for CGC-9 Leached at $90^{\circ} \mathrm{C} \quad$. 21

10 Normalized Elemental Losses $\left(\mathrm{NL}_{i}\right)$ for CGC-HMI Leached at $90^{\circ} \mathrm{C} \quad$. $\quad 21$

11 Normalized Elemental Losses $\left(\mathrm{NL}_{j}\right)$ for $\mathrm{FGC}-9$ Leached at $90^{\circ} \mathrm{C}$. 22

12 Normalized Elemental Losses $\left(\mathrm{NL}_{i}\right)$ for $\mathrm{FGC}-\mathrm{M} 4$ Leached at $90^{\circ} \mathrm{C} . \quad$. 23

B.1 Normalized Elemental Losses $\left(\mathrm{NL}_{j}\right)$ for BGC-4 Leached at $90^{\circ} \mathrm{C}$

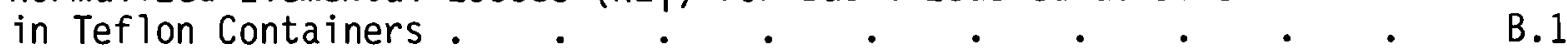

B.2 Normalized Elemental Losses ( $\mathrm{NL}_{j}$ ) for CGC-HMI Leached at $90^{\circ} \mathrm{C}$

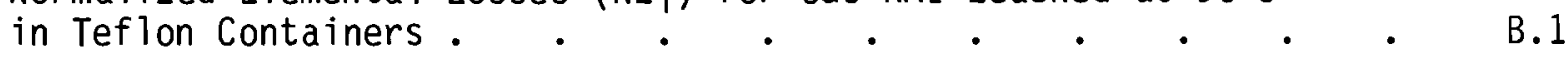

B.3 Normalized Elemental Losses $\left(\mathrm{NL}_{i}\right)$ for $76-68$ Glass Leached at $90^{\circ} \mathrm{C}$ in Polypropylene Containers 
: 


\section{INTRODUCTION}

One important aspect of radioactive waste management involves the solidification of the waste into a stable solid. The two solid hosts having received the greatest development for high-level wastes (HLW) are glasses and crystalline ceramics. Borosilicate glasses, which are the most widely studied waste form, in the ideal case homogeneously incorporate fission products, transuranics, corrosion products and processing chemicals. In practice, waste glasses often contain a small percentage of undissolved oxides $\left(\mathrm{RuO}_{2}, \mathrm{CeO}_{2}, \mathrm{ZrO}_{2}\right)$ and noble metals (Rh, Pd) (Guber et al. 1979). Other secondary phases such as spinel and a water soluble molybdate (Wald and Westsik 1979) have also received special attention in glass development studies. All of these may act as nuclei for further crystallization. In a supercooled state, glasses are highly resistant to alteration; however, as the viscosity decreases (i.e., at high temperatures), the susceptibility for structural change (crystallization) increases. Spontaneous crystallization may occur at temperatures between the glass softening point and the liquidus temperature. If not controlled, unfavorable phases and/or microstructures may form. This tendency, along with the possibility of forming stable, highly durable crystalline phases, led to evaluation of glass ceramics as possible waste forms, especially at the Hahn Meitner Institute (De, et al. 1976, De, et a). 1977, and Lutze, et a). 1979) but also in Japan (Oguino, et al. 1979) and at Battelle's Pacific Northwest Laboratory (Lokken and Rusin 1980).

Glass ceramics, as the term implies, are glasses which have been either partially or completely crystallized through controlled heat-treatment processes. Commercial glass ceramics are designed for maximum crystallinity (>98\%) (McMillan 1979) while glass ceramics studied for radioactive waste may contain less than $35 \%$ crystals (Lutze, et al. 1979). The structure of these materials has been intentionally altered to provide greater resistance to further, undesirable crystallization at elevated temperatures, and to improve thermal and mechanical properties. The preparation of glass ceramics requires a chemical composition such that the material can be homogeneously melted, shaped or cast, 
and cooled to below the annealing point while maintaining its vitreous condition. In addition, the material must contain a nucleation catalyst upon which crystal phases may grow. One of the main requirements of a crystallization catalyst or nucleating agent is the capability of existing in the glass as a dispersion of particles of colloidal dimensions (McMillan 1979). Nucleating agents may include metallic colloids, oxides, or halides. As suggested above, HLW ordinarily includes a variety of suitable nucleating metallic and oxide phases without requiring additional additives.

Numerous glass ceramic compositions have been studied for solidification of high-level radioactive waste as reviewed by Rusin (1931). Several compositions merited further study. This report describes the preparation and leach testing of celsian, fresnoite, and basalt glass ceramics. Celsian and fresnoite glass ceramics were prepared with simulated power reactor waste calcines used in their development at the Hahn Meitner Institute (Lutze, et al. 1979) and one additional composition. Basalt glass ceramics were studied because of the possibility of producing a waste form in near equilibrium with the final rock system. Basalt dominates the geology of any possible Hanford repository, as being evaluated by the Basalt Waste Isolation Project (Deju and Evans 1980). Basalt glass ceramics in this study were prepared with Pomona basalt and three simulated power reactor waste calcines to assess the ability of basalt to accept variations in waste stream composition. The waste loading of all materials tested was $20 \mathrm{wt} \%$ on an oxide basis. The glass ceramics were tested for chemical durability using procedures similar to those defined by the Nuclear Waste Materials Characterization Center for the MCC-1 Static Leach Test. 


\section{EXPERIMENTAL}

\section{MATERIAL PREPARATION}

Eight materials were prepared for characterization and leach testing, including three types of glass ceramics and one parent glass. Each waste form contained $20 \mathrm{wt} \%$ simulated waste calcine. The materials included:

- Basalt glass ceramic with PW-9 calcine (BGC-9)

- Basalt glass ceramic with PW-4b-7 calcine (BGC-4)

- Basalt glass ceramic with PW-8a-2 calcine (BGC-8)

- Basalt glass with PW-8a-2 calcine (BG-8)

- Celsian glass ceramic with PW-9 calcine (CGC-9)

- Celsian glass ceramic with HMI calcine (CGC-HMI)

- Fresnoite glass ceramic with PW-9 calcine (FGC-9)

- Fresnoite glass ceramic with modified PW-4b-7 calcine (FGC-M4)

The abbreviations noted in the above list will be used in following discussions.

$\underline{\text { Basalt }}$

Four basalt-based products were prepared by melting 80 wt\% Pomona basalt $(-25+70$ mesh) with 20 wt\% simulated high-level waste calcine. Three types of calcine were used-PW-9, PW-4b-7, and PW-8a-2. Each mixture was melted for 2 hours in platinum crucibles at $1300^{\circ} \mathrm{C}$ in air. After an additional 10 minutes at $1400^{\circ} \mathrm{C}$ (to aid in casting) the glass was poured into a heated steel bar mold and when the temperature was $\sim 700^{\circ} \mathrm{C}$, the glass bar was transferred to an annealing furnace operating at $550^{\circ} \mathrm{C}$. Following 2 hours of annealing the sample was slow cooled to room temperature. The glass bars were nominally $19 \mathrm{~mm}$ by $19 \mathrm{~mm}$ by $75 \mathrm{~mm}$. A bar of each material was then heat treated for controlled crystallization using a two-stage process developed at Corning (Beall and Rittler 1976$)$. The materials were heated at $240^{\circ} \mathrm{C} / \mathrm{h}$ to $670^{\circ} \mathrm{C}$ for 1 hour, followed by $240^{\circ} \mathrm{C} / \mathrm{h}$ to $920^{\circ} \mathrm{C}$ and held for 8 hours.

Celsian

Two simulated waste calcines were incorporated in a celsian-based material. One was PW-9 calcine, the other a simulated calcine from HMI. The 
latter calcine was used in developing the composition and heat treatment schedule for celsian glass ceramics. The celsian glass mixture was prepared with oxides and carbonates plus 20 wt\% simulated calcine powder on an oxide basis. The mixture was melted at $1200^{\circ} \mathrm{C}$ for 2 hours and cast into bars as described above. The materials were annealed for 2 hours at $500^{\circ} \mathrm{C}$, slow cooled to room temperature, and heat treated. Again a two-stage heat treating schedule was used, nucleating at $600^{\circ} \mathrm{C}$ for 3 hours, followed by a 12 hour crystallization treatment at $800^{\circ} \mathrm{C}$.

\section{Fresnoite}

Fresnoite glass ceramics, like the celsian type, were also developed at HMI. This type of glass ceramic is formulated without boron in an effort to increase the durability of the residual vitreous phase remaining after crystallization. Materials for this study were prepared with $20 \mathrm{wt} \% \mathrm{PW}-9$ calcine and $20 \mathrm{wt} \% \mathrm{PW}-4 \mathrm{~b}-7$ calcine containing additions of $0.46 \mathrm{wt} \% \mathrm{Eu}_{2} \mathrm{O}_{3}$ and $0.32 \mathrm{wt} \%$ $\mathrm{MnO}_{2}$. The two additions to $\mathrm{PW}-4 \mathrm{~b}-7$ were necessary to approximate the composition of the HMI calcine used in the development of fresnoite glass ceramics. Chemical oxides were mixed with $20 \mathrm{wt} \%$ waste calcine and melted for 2 hours at $1200^{\circ} \mathrm{C}$ and cast into heated steel bar molds. The glass bars were annealed for 2 hours at $500^{\circ} \mathrm{C}$ and furnace cooled to room temperature. Crystallization was affected by heating at $250^{\circ} \mathrm{C} / \mathrm{h}$ to $700^{\circ} \mathrm{C}$, holding for 4 hours, heating to $860^{\circ} \mathrm{C}$ at $250^{\circ} \mathrm{C} / \mathrm{h}$, holding for 12 hours, and slow cooling to room temperature.

\section{Composition}

The nominal compositions of the base materials for the three glass ceramic materials are listed in Table 1. The materials comprised $80 \mathrm{wt} \%$ of the waste forms with various simulated calcines making up the balance. Table 2 shows the nominal and analyzed oxide composition of the materials after preparation. The materials were analyzed by a $\mathrm{KOH}$ or $\mathrm{NaOH}$ fusion/ICP technique.

One concern expressed with the use of high-melting temperature glasses is that of volatility of certain waste constituents. An approximation of volatility losses was made by comparing the analyzed compositions of the starting materials with those of the prepared waste forms. Cesium was found to be one 
TABLE 1. Oxide Composition of Base Materials for Basalt, Celsian, and Fresnoite Glass Ceramics

\begin{tabular}{|c|c|c|c|}
\hline Oxide & Basalt & Celsian & Fresnoite \\
\hline $\mathrm{Al}_{2} \mathrm{O}_{3}$ & 13.90 & 16.1 & - \\
\hline $\mathrm{CaO}$ & 10.20 & 5.0 & - \\
\hline $\mathrm{Fe}_{2} \mathrm{O}_{3}$ & 11.70 & - & - \\
\hline $\mathrm{K}_{2} \mathrm{O}$ & 0.50 & - & - \\
\hline MgO & 6.68 & 1.5 & 6.25 \\
\hline $\mathrm{MnO}_{2}$ & 0.20 & - & - \\
\hline $\mathrm{SiO}_{2}$ & 51.70 & 35.2 & 25.00 \\
\hline $\mathrm{TiO}_{2}$ & 1.60 & 5.0 & 18.75 \\
\hline $\mathrm{Na}_{2} \mathrm{O}$ & 2.73 & 2.0 & - \\
\hline $\mathrm{B}_{2} \mathrm{O}_{3}$ & - & 8.0 & - \\
\hline $\mathrm{Li}_{2} \mathrm{O}$ & - & 3.0 & - \\
\hline $\mathrm{BaO}$ & - & 18.6 & 35.00 \\
\hline $\mathrm{ZrO}_{2}$ & - & 1.0 & - \\
\hline $\mathrm{ZnO}$ & - & 4.5 & - \\
\hline \multirow[t]{2}{*}{$\mathrm{PbO}_{2}$} & - & - & 15.00 \\
\hline & 99.2 & 99.9 & 100.0 \\
\hline
\end{tabular}

of the most volatile of the elements considered with losses of 43,38 , and $32 \mathrm{wt} \%$ Cs from BGC-9, BGC-4, and BGC-8, respectively. These materials were melted in air at $1300^{\circ} \mathrm{C}$ for 2 hours. Similarly, the weight percent of cesium lost from CGC-9 and FGC-9 after 2 hours at $1200^{\circ} \mathrm{C}$ was 19 and $59 \mathrm{wt} \%$, respectively. These values are not unrealistic with respect to losses from other high-level waste glasses (Gray 1980). For example, 72-68 glass demonstrated cesium losses of 30 and $100 \mathrm{wt} \%$ at 1100 and $1200^{\circ} \mathrm{C}$, respectively. The volatil losses of molybdenum and sodium from the glass ceramics were near zero.

\section{CHARACTERIZATION}

The eight waste forms described in the previous section were characterize by optical and scanning electron microscopy, energy dispersive $x$-ray analys is (EDAX), x-ray diffraction, and immersion density measurements. 
TABLE 2. Nominal and Analyzed(a) Composition of Glass Ceramic Waste Forms, Wt\%

\begin{tabular}{|c|c|c|c|c|c|c|c|}
\hline \multirow{2}{*}{\multicolumn{2}{|c|}{$\begin{array}{c}\text { Detection } \\
\text { Limit } \\
\text { (ppm) } \\
\end{array}$}} & \multicolumn{2}{|c|}{$\mathrm{BGC}-9$} & \multicolumn{2}{|c|}{$\mathrm{BGC}-8$} & \multicolumn{2}{|c|}{ BGC-4 } \\
\hline & & Nominal & Analyzed & Nominal & Analyzed & Nominal & Analyzed \\
\hline $\mathrm{Al}_{2} \mathrm{O}_{3}$ & 0.03 & 11.13 & 11.1 & 11.13 & 10.8 & 11.15 & 10.1 \\
\hline $\mathrm{B}_{2} \mathrm{O}_{3}$ & 0.01 & 0.01 & 0.08 & 0.01 & 0.04 & 0.03 & 0.07 \\
\hline $\mathrm{BaO}$ & 0.002 & 0.67 & 0.73 & 0.25 & 0.30 & 0.50 & 0.50 \\
\hline $\mathrm{CaO}$ & 0.01 & 8.24 & 8.65 & 8.26 & 8.19 & 8.26 & 7.66 \\
\hline $\mathrm{CdO}$ & 0.004 & 0.07 & 0.07 & 0.02 & 0.02 & 0.04 & 0.4 \\
\hline $\mathrm{Ce}_{2} \mathrm{O}_{3}$ & 0.04 & 1.11 & 1.45 & 1.84 & 2.00 & 1.19 & 1.22 \\
\hline $\mathrm{CoO}_{3}$ & 0.01 & 0.13 & 0.16 & 0.05 & 0.07 & 0.03 & 0.01 \\
\hline $\mathrm{Cr}_{2} \mathrm{O}_{3}$ & 0.02 & 0.18 & 0.21 & 0.22 & 0.24 & 0.17 & 0.15 \\
\hline $\mathrm{CuO}_{2}$ & 0.004 & - & 0.01 & - & - & - & - \\
\hline $\mathrm{Dy}_{2} \mathrm{O}_{3}$ & 0.004 & 0.02 & 0.02 & 0.02 & 0.02 & 0.01 & 0.01 \\
\hline $\mathrm{Eu}_{2} \mathrm{O}_{3}$ & 0.002 & - & 0.01 & 0.01 & 0.01 & 0.08 & 0.08 \\
\hline $\mathrm{Fe}_{2} \mathrm{O}_{3}$ & 0.005 & 9.98 & 10.2 & 13.96 & 13.9 & 10.1 & 9.36 \\
\hline $\mathrm{Gd}_{2} \mathrm{O}_{3}$ & 0.01 & 0.08 & 0.08 & 0.07 & 0.07 & 0.08 & 0.08 \\
\hline $\mathrm{K}_{2} \mathrm{O}$ & 0.3 & 0.42 & 0.72 & 0.46 & 0.87 & 0.40 & 0.6 \\
\hline $\mathrm{La}_{2} \mathrm{O}_{3}$ & 0.008 & 0.85 & 0.95 & 0.93 & 0.95 & 0.59 & 0.58 \\
\hline $\mathrm{Li}_{2} \mathrm{O}$ & 0.004 & - & 0.02 & - & 0.02 & - & 0.01 \\
\hline $\mathrm{MgO}$ & 0.06 & 5.37 & 5.06 & 5.37 & 4.98 & 5.37 & 4.82 \\
\hline $\mathrm{MnO}_{2}$ & 0.002 & 0.17 & 0.19 & 0.17 & 0.18 & 0.17 & 0.18 \\
\hline $\mathrm{MoO}_{3}$ & 0.01 & 2.80 & 2.73 & 1.09 & 1.16 & 2.24 & 2.12 \\
\hline $\mathrm{Na}_{2} \mathrm{O}$ & 0.01 & 5.30 & 7.16 & 5.36 & 6.11 & 4.36 & 6.10 \\
\hline $\mathrm{Nd}_{2} \mathrm{O}_{3}$ & 0.02 & 0.60 & 0.67 & 0.78 & 0.80 & 1.68 & 1.64 \\
\hline $\mathrm{NiO}$ & 0.02 & 0.40 & 0.43 & 0.24 & 0.21 & 0.05 & 0.05 \\
\hline $\mathrm{P}_{2} \mathrm{O}_{5}$ & 0.1 & 0.28 & 0.6 & 0.24 & 0.4 & 0.26 & 0.4 \\
\hline $\mathrm{PbO}$ & 0.06 & - & 0.06 & - & 0.07 & - & 0.15 \\
\hline $\mathrm{RuO}_{2}$ & 0.05 & 0.36 & 0.06 & 0.07 & - & 1.16 & 0.09 \\
\hline $\mathrm{SiO}_{2}$ & 0.02 & 41.39 & 40.2 & 41.42 & 39.8 & 41.59 & 37.2 \\
\hline Sro & 0.002 & 0.50 & 0.58 & 0.18 & 0.21 & 0.41 & 0.43 \\
\hline $\mathrm{TeO}_{2}$ & 0.06 & 0.26 & 0.22 & 0.10 & 0.12 & 0.22 & 0.10 \\
\hline $\mathrm{TiO}_{2}$ & 0.002 & 1.29 & 1.42 & 1.28 & 1.37 & 1.29 & 1.31 \\
\hline Zno & 0.02 & 0.01 & - & - & - & 0.20 & - \\
\hline $\mathrm{ZrO}_{2}$ & 0.008 & 0.92 & 1.89 & 0.79 & 0.64 & 1.32 & 1.98 \\
\hline $\mathrm{Cs}_{2} \mathrm{O}^{(\mathrm{b})}$ & 0.05 & 1.25 & 0.71 & 0.50 & 0.34 & 1.09 & 0.68 \\
\hline TOTAL & & 93.8 & 96.4 & 94.8 & 94.0 & 93.8 & 88.3 \\
\hline
\end{tabular}

(a) Analyzed by ICP with $\mathrm{KOH}$ fusion.

(b) Analyzed by Atomic Adsorption. 
TABLE 2. (contd)

\begin{tabular}{|c|c|c|c|c|c|c|c|}
\hline & & & CGC-HMI & & & & \\
\hline & Nominal & Analyzed & Nominal(d) $\quad$ Analyzed & Nominal & Analyzed & Nominal & Analyzed \\
\hline $\mathrm{Al}_{2} \mathrm{O}_{3}$ & 12.89 & 11.0 & 10.8 & 0.01 & 1.1 & 0.03 & 0.88 \\
\hline $\mathrm{B}_{2} \mathrm{O}_{3}$ & 6.41 & 8.26 & 7.99 & 0.01 & 0.055 & 0.03 & - \\
\hline $\mathrm{BaO}$ & 15.55 & 15.3 & 14.8 & 28.67 & 28.3 & 28.48 & 26.6 \\
\hline $\mathrm{CaO}$ & 4.08 & 4.08 & 3.94 & 0.08 & 0.14 & 0.09 & 0.40 \\
\hline $\mathrm{CdO}$ & 0.07 & 0.07 & - & 0.07 & 0.07 & 0.04 & 0.04 \\
\hline $\mathrm{Ce}_{2} \mathrm{O}_{3}$ & 1.11 & 1.15 & 1.04 & 1.11 & 1.09 & 1.15 & 1.25 \\
\hline $\mathrm{CoO}_{3}$ & 0.13 & 0.14 & - & 0.13 & 0.16 & 0.02 & - \\
\hline $\mathrm{Cr}_{2} \mathrm{O}_{3}$ & 0.18 & 0.18 & 0.36 & 0.18 & 0.18 & 0.17 & 0.14 \\
\hline $\mathrm{CuO}_{2}$ & - & 0.01 & 0.12 & - & 0.06 & - & 0.16 \\
\hline $\mathrm{Dy}_{2} \mathrm{O}_{3}$ & 0.02 & 0.02 & 0.01 & 0.02 & 0.02 & 0.01 & 0.01 \\
\hline $\mathrm{Eu}_{2} \mathrm{O}_{3}$ & - & 0.01 & - & - & - & 0.59 & 0.54 \\
\hline $\mathrm{Fe}_{2} \mathrm{O}_{3}$ & 0.62 & 0.68 & 1.55 & 0.62 & 0.76 & 0.62 & 0.89 \\
\hline $\mathrm{Gd}_{2} \mathrm{O}_{3}$ & 0.08 & 0.10 & - & 0.08 & 0.14 & 0.07 & - \\
\hline $\mathrm{K}_{2} \mathrm{O}^{0}$ & 0.42 & 0.27 & - & 0.02 & - & - & - \\
\hline $\mathrm{La}_{2} \mathrm{O}_{3}$ & 0.85 & 0.88 & 0.55 & 0.85 & 0.88 & 0.57 & 0.65 \\
\hline $\mathrm{Li}_{2} \mathrm{O}$ & 2.40 & 2.38 & 2.58 & - & 0.03 & - & - \\
\hline $\mathrm{MgO}$ & 1.23 & 1.21 & 1.17 & 5.03 & 4.57 & 5.02 & 4.65 \\
\hline $\mathrm{MnO}_{2}$ & 0.01 & 0.01 & 0.27 & 0.01 & - & 0.33 & 0.35 \\
\hline $\mathrm{MoO}_{3}$ & 2.80 & 2.78 & 2.19 & 2.80 & 2.92 & 2.15 & 2.16 \\
\hline $\mathrm{Na}_{2} \mathrm{O}$ & 4.72 & 5.38 & 4.16 & 3.12 & 5.09 & 2.09 & 4.33 \\
\hline $\mathrm{Nd}_{2} \mathrm{O}_{3}$ & 0.60 & 0.62 & 1.94 & 0.60 & 0.63 & 1.62 & 1.81 \\
\hline $\mathrm{NiO}$ & 0.40 & 0.4 & 0.22 & 0.40 & - & 0.05 & 0.05 \\
\hline $\mathrm{P}_{2} \mathrm{O}_{5}$ & 0.28 & 0.32 & 0.58 & 0.28 & 0.28 & 0.25 & 0.85 \\
\hline $\mathrm{PbO}$ & - & 0.12 & - & 12.00 & 10.5 & 12.00 & 10.10 \\
\hline $\mathrm{RuO}_{2}$ & 0.36 & 0.24 & - & 0.36 & 0.17 & 1.11 & 1.05 \\
\hline $\mathrm{SiO}_{2}$ & 28.19 & 28.8 & 27.2 & 20.03 & 23.6 & 20.22 & 21.7 \\
\hline Sro & 0.50 & 0.59 & 0.61 & 0.50 & 0.65 & 0.40 & 0.54 \\
\hline $\mathrm{TeO}_{2}$ & 0.26 & 0.30 & 0.23 & 0.26 & 0.29 & 0.21 & 0.24 \\
\hline $\mathrm{TiO}_{2}$ & 4.01 & 4.35 & 4.42 & 15.01 & 19.9 & 15.01 & 15.1 \\
\hline $\mathrm{ZnO}$ & 3.61 & 3.69 & 3.46 & 0.01 & 0.03 & 0.02 & - \\
\hline $\mathrm{ZrO}_{2}$ & 1.72 & 3.05 & - & 0.92 & 2.24 & 1.27 & - \\
\hline $\mathrm{Cs}_{2} \mathrm{O}^{\mathrm{C}}(\mathrm{b})$ & $\underline{1.25}$ & 1.01 & 1.38 & 1.25 & 0.51 & 1.05 & 0.88 \\
\hline TOTAL & 95.8 & 96.4 & 91.6 & 94.4 & 100.4 & 94.7 & 95.4 \\
\hline
\end{tabular}

(a) Nominal composition not available.

(b) Analyzed by Atomic Adsorption. 


\section{Microstructure}

Optical micrographs of the basalt glass ceramics are shown in Figure 1. The three materials-BGC-9, BGC-4, and BGC-8-are characterized by fine, homogeneous textures. The small bright particles, seen in the upper right of the BGC-8 optical micrograph, are detailed in a SEM micrograph also seen in Figure 1. Two particle shapes are seen in the figure--semirectangular, and dendritic. Both were identified by EDAX as spinel composed of Fe, $\mathrm{Cr}$, Ni, and Ru. Similar particles are seen in the BG-8 sample as evidenced by Figure 2 . The optical micrograph reveals a large number of spinel particles; these are detailed by SEll in the micrograph on the right.

The celsian glass ceramic microstructures are characterized by more irregularities than the basalt glass ceramics, as seen in Figure 3. CGC-9 contains light-colored inclusions within a grainy matrix. Examination at lower magnification reveals small amounts of porosity. The microstructure of CGC-HMI is characterized by needle-like crystals and small bright particles within a gray matrix. The bright particles were identified by EDAX as scheelite, while the needle-like features are celsian crystals.

The microstructures of fresnoite glass ceramics are shown in Figure 4. FGC-9 is similar in appearance to the basalt glass ceramics being fine-grained. The microstructure of FGC-M4 is characterized by numerous crystal clusters within a fine-textured matrix. The structure is seen more clearly in the SEM micrographs which reveal four distinct features. The bright particles were identified by EDAX as palladium. Unlike the celsian glass ceramics, individual phases cannot be clearly identified because of numerous peak overlaps, i.e., barium and titanium, molybdenum and lead. The dark area of the matrix, which is similar in texture with the lighter, continuous matrix, is enriched in magnesium.

\section{X-Ray Diffraction}

During the heat treatment of the basalt glass ceramics three principal phases crystallized. These phases and their relative yield, based on $\mathrm{Al}_{2} \mathrm{O}_{3}$ ' glass standards with a relative standard deviation of $\pm 10 \%$, are listed in 


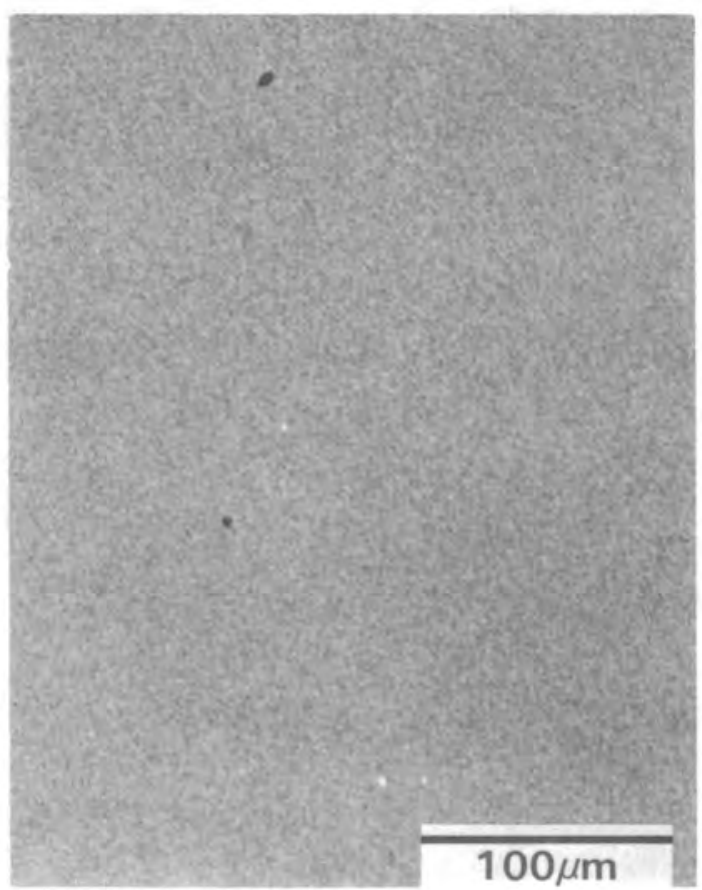

BGC-9

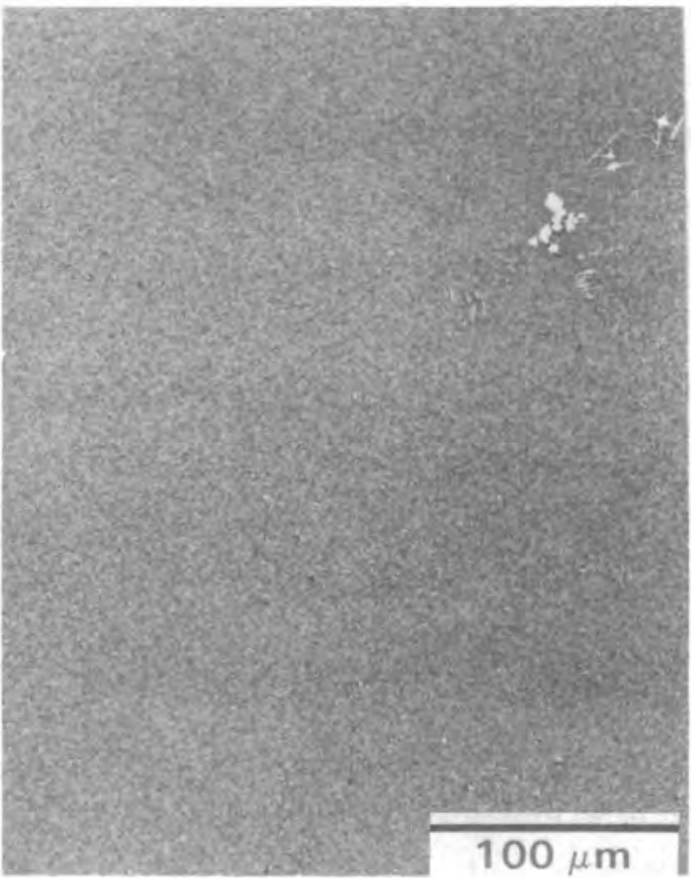

BGC-8

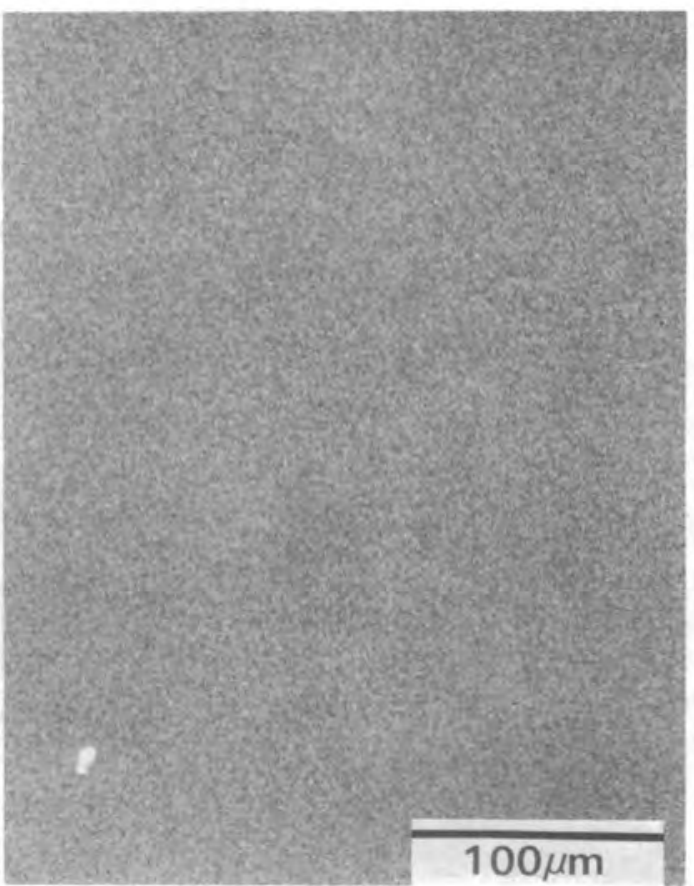

BGC-4

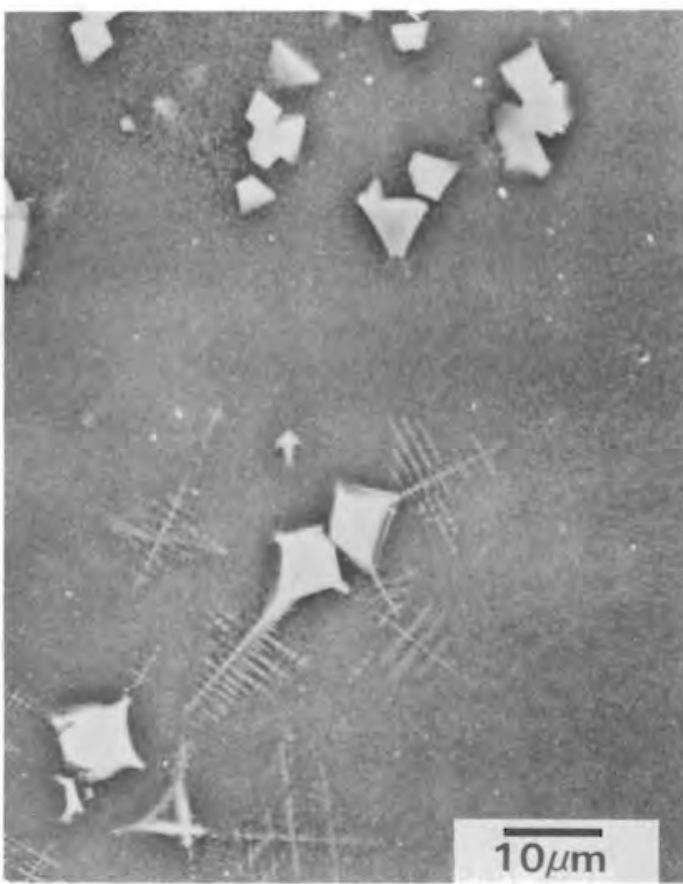

BGC-8

FIGURE 1. Micrographs of Basalt Glass Ceramics 


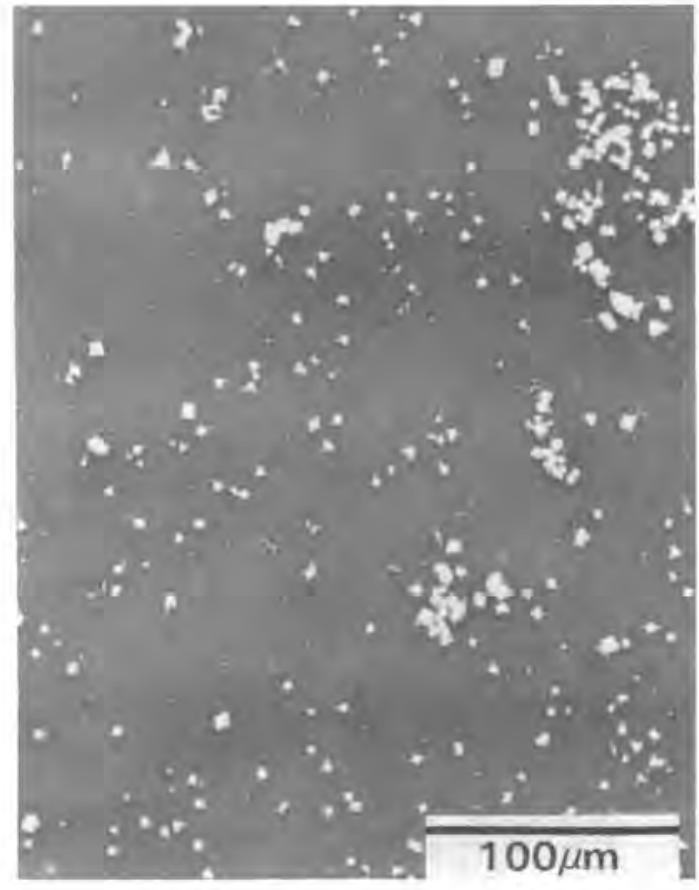

BG-8

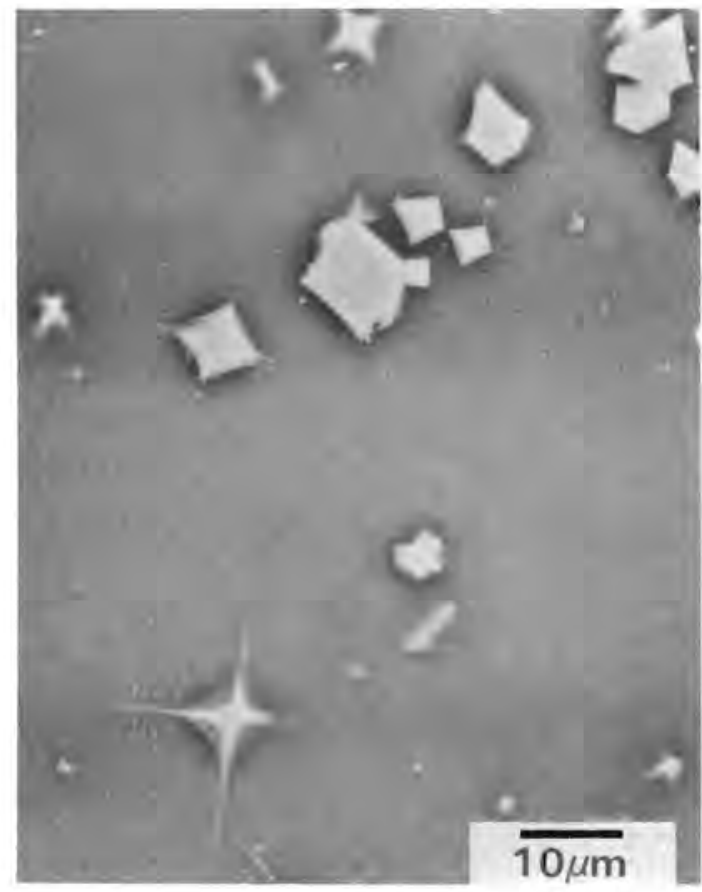

BG-8

FIGURE 2. Micrographs of Basalt Glass

Table 3. The most abundant phase in BGC-9 and BGC-4 is augite while the most abundant phase in BGC-8 is spinel because of the higher iron content in $\mathrm{PW}-8 \mathrm{a}-2$. The only phase detected in $\mathrm{BG}-8$ was spinel which formed during preparation. The celsian glass ceramics also had three crystalline phases with a celsian $\left(\mathrm{BaAl}_{2} \mathrm{Si}_{2} \mathrm{O}_{8}\right)$ phase most prominant (see Table 3). CGC-9 contained the largest total crystallinity-24 wt\% compared to $20 \mathrm{wt} \%$ in CGC-HMI. Although the total crystallinity of FGC-9 and FGC-M4 are nearly equal the partitioning of the phases are different. FGC-9 contains a larger fraction of scheelite and perovskite than FGC-M4; the fresnoite phase is more prominant in FGC-M4.

\section{Bulk Density}

The densities of the eight waste forms are presented in Table 4. The density of the basalt glass ceramics are nearly equal at $3.1 \mathrm{~g} / \mathrm{cm}^{3}$. After recrystallization of BG-8, density increased from $2.96 \mathrm{~g} / \mathrm{cm}^{3}$ to $3.09 \mathrm{~g} / \mathrm{cm}^{3}$. Fresnoite glass ceramics had the highest density-4.2 - $4.3 \mathrm{~g} / \mathrm{cm}^{3}$-because of their high lead content. 


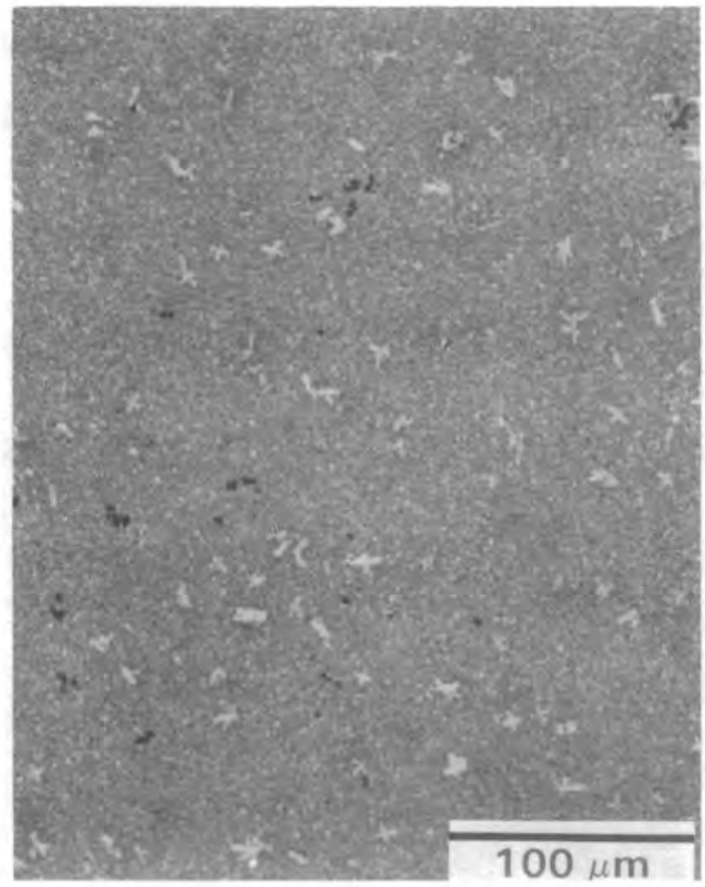

CGC-9

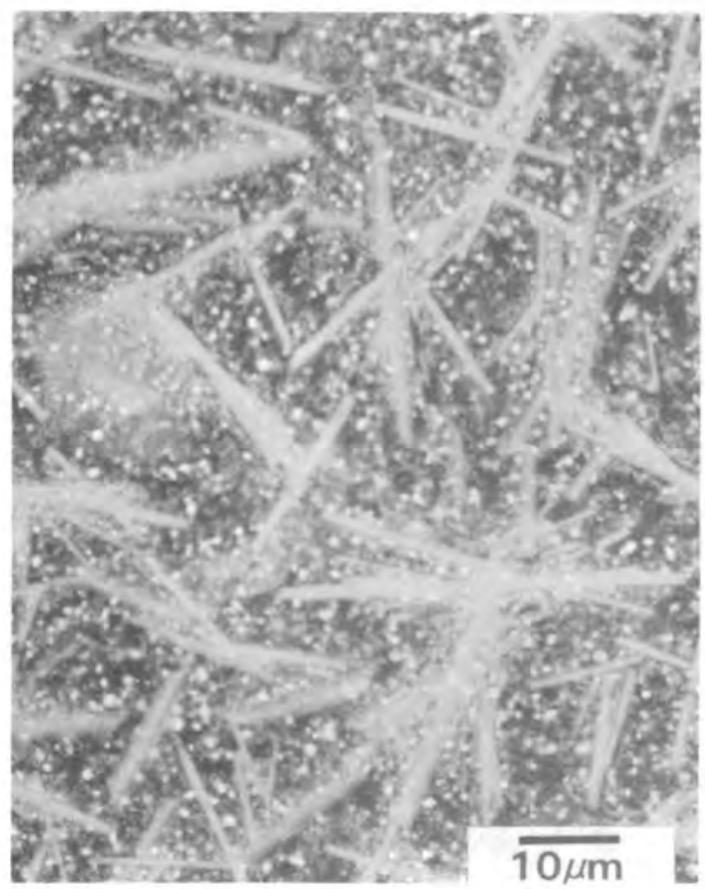

CGC-HMI

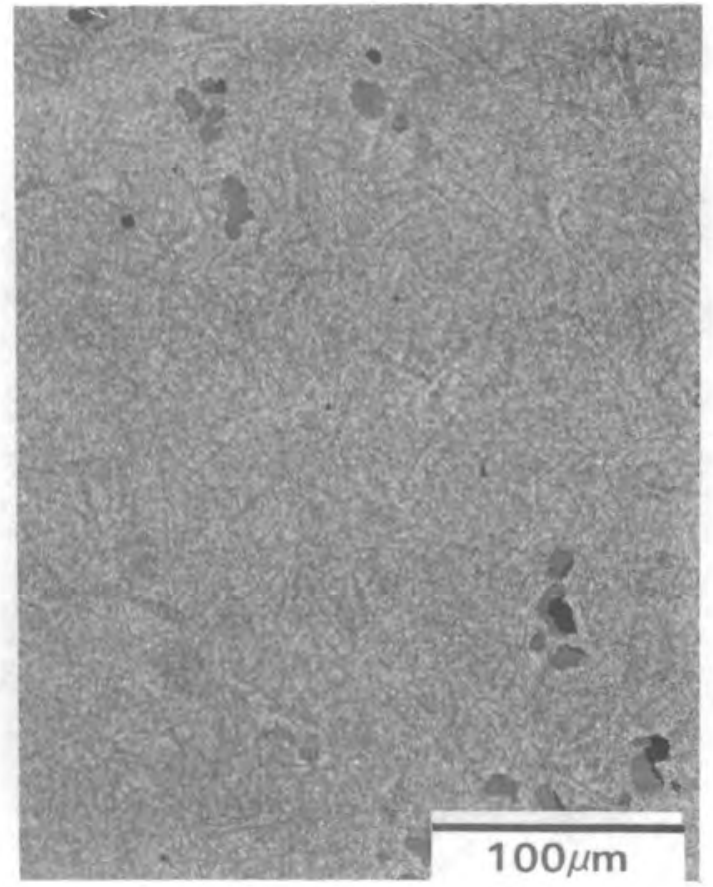

CGC-HMI

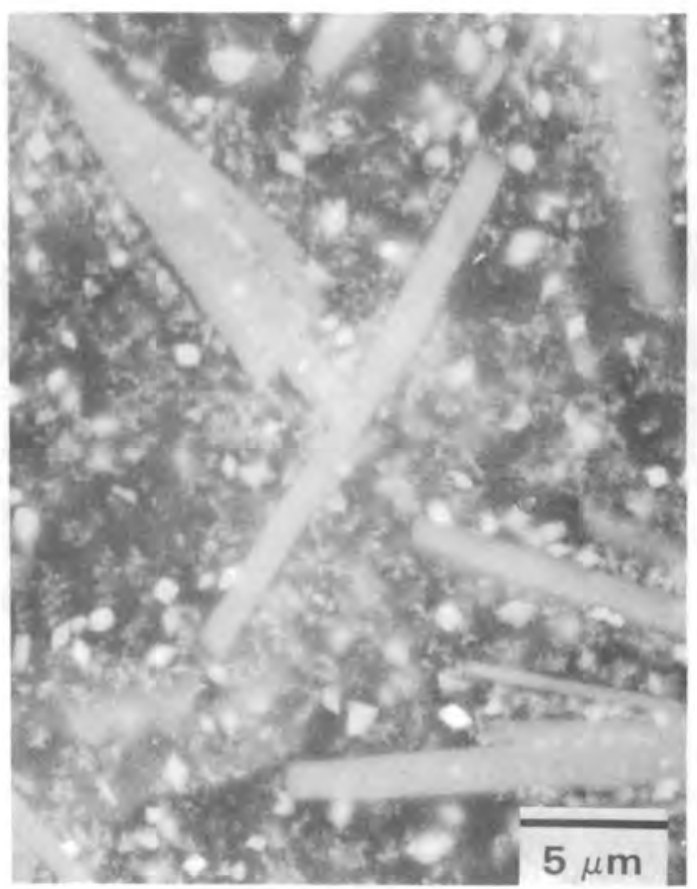

CGC-HMI

FIGURE 3. Micrographs of Celsian Glass Ceramics 


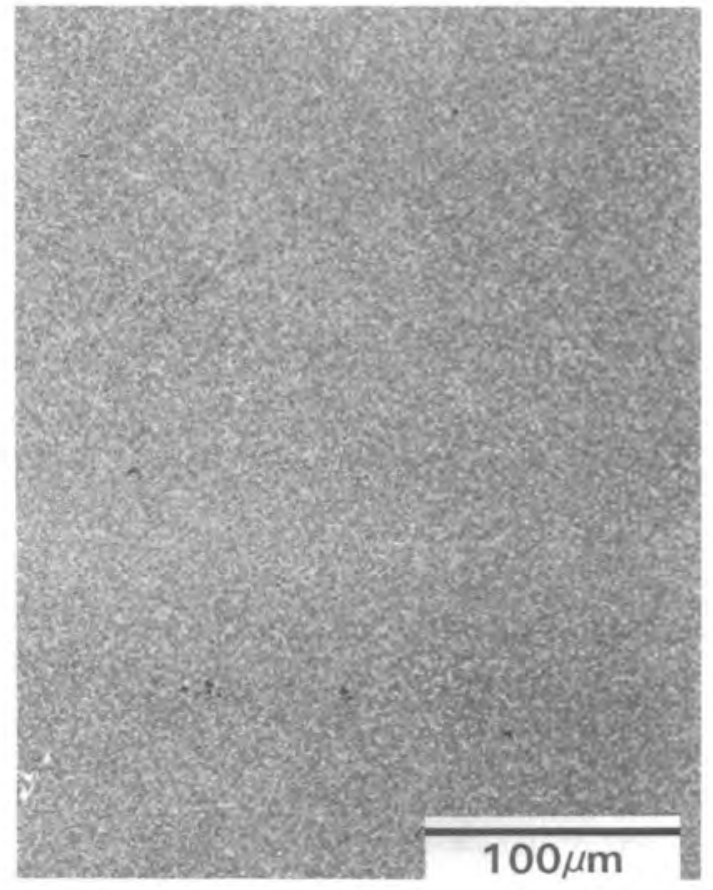

FGC-9

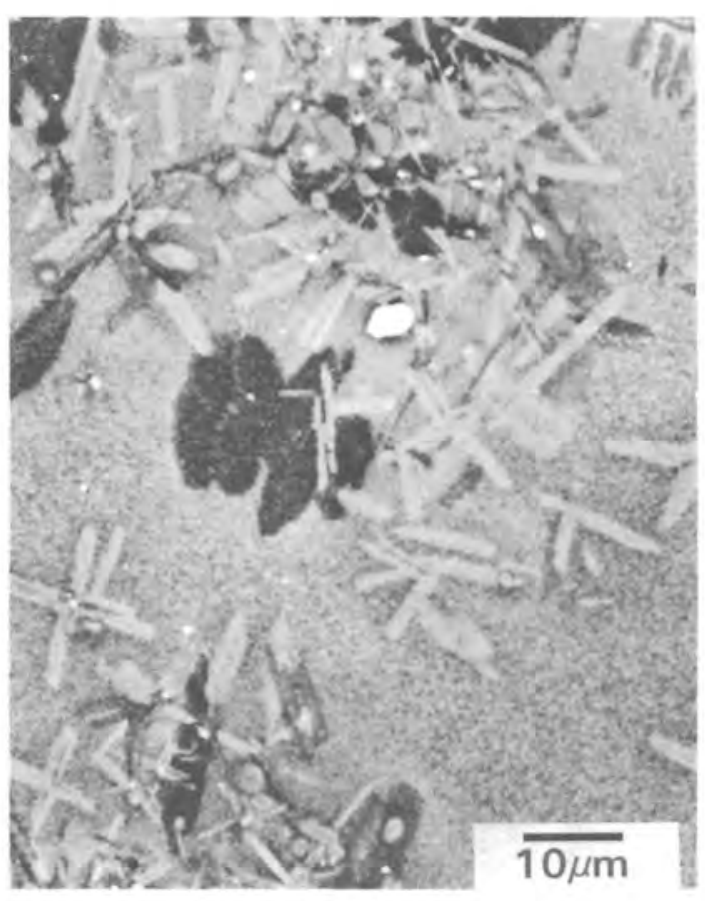

FGC-M4

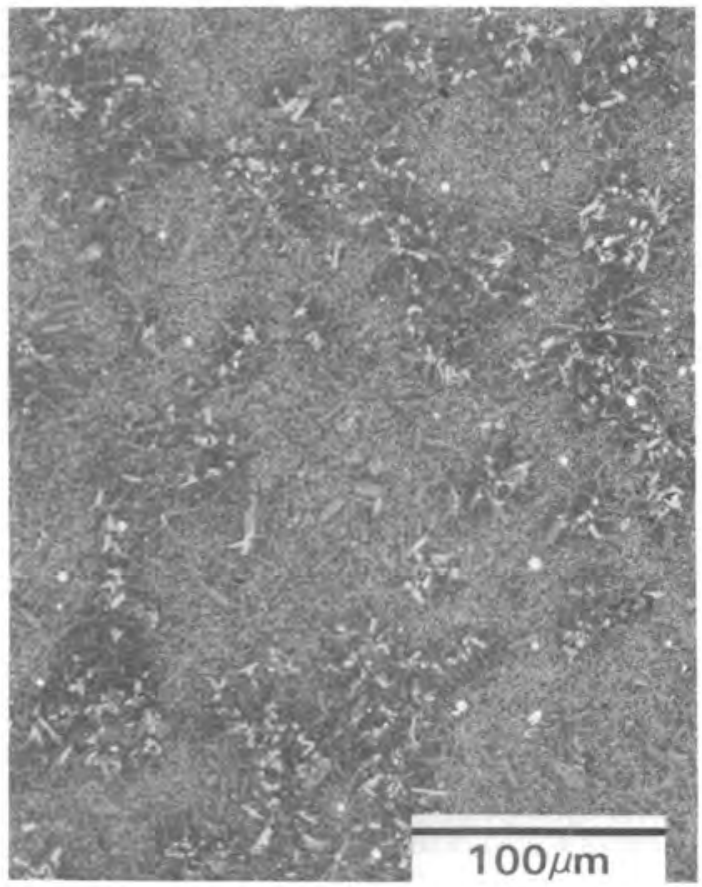

FGC-M4

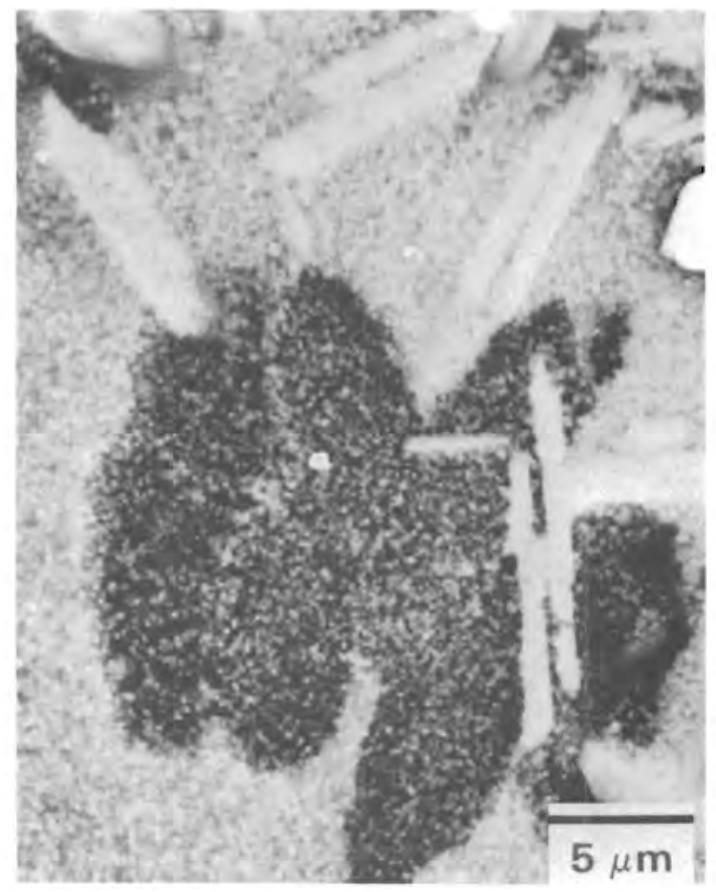

FGC-M4

FIGURE 4. Micrographs of Fresnoite Glass Ceramics 
TABLE 3. Crystalline Phase Yield in Glass Ceramics, wt\%(a)

\begin{tabular}{|c|c|c|c|c|}
\hline & $\begin{array}{c}\text { Augite } \\
(\mathrm{Ca}, \mathrm{Fe}, \mathrm{Mg}) \mathrm{SiO}_{3}\end{array}$ & $\begin{array}{l}\text { Spine } 1 \\
\mathrm{NiFe}_{2}{ }_{-}\end{array}$ & $\begin{array}{l}\text { Powe } 11 \text { ite } \\
(\mathrm{Ca}, \mathrm{Sr}) \mathrm{MoO}_{4}\end{array}$ & Total \\
\hline BGC-9 & 7 & 4 & 5 & 16 \\
\hline$B G C-4$ & 12 & 6 & 4 & 22 \\
\hline$B G C-8$ & 7 & 8 & 2 & 17 \\
\hline \multirow[t]{2}{*}{$B G-8$} & - & 3 & - & 3 \\
\hline & $\begin{array}{c}\text { Celsian } \\
\mathrm{BaAl} 2 \mathrm{Si}_{2}-_{-8}\end{array}$ & $\begin{array}{l}\text { Schee lite } \\
\mathrm{BaMoO}_{4}\end{array}$ & $\begin{array}{l}\text { Pyrochlore } \\
\left(\text { R.E.) }{ }_{2}{ }^{T i} 2-{ }_{-}^{0}\right.\end{array}$ & Total \\
\hline CGC-9 & 12 & 6 & 6 & 24 \\
\hline \multirow[t]{2}{*}{ CGC-HMI } & 9 & 5 & 6 & 20 \\
\hline & $\begin{array}{l}\text { Fresnoite } \\
\mathrm{Ba} \text { TiSi }\end{array}$ & $\begin{array}{l}\text { Schee lite } \\
\mathrm{BaMlOO}_{4}\end{array}$ & $\begin{array}{c}\text { Perovskite } \\
\mathrm{Ca}\left(\text { R.E.,Ti) } 0_{3}\right.\end{array}$ & Total \\
\hline$F G C-9$ & 15 & 6 & 9 & 30 \\
\hline FGC-M4 & 21 & 4 & 6 & 31 \\
\hline
\end{tabular}

(a) Crystaline yield is $\pm 10 \%$ of listed value.

TABLE 4. Densities of Glass Ceramic Waste Forms

$\begin{array}{ll}\frac{\text { Waste Form }}{\text { BGC-9 }} & \frac{\text { Density, } \mathrm{g} / \mathrm{cm}^{3}}{3.071 \pm 0.001} \\ \text { BGC-4 } & 3.105 \pm 0.007 \\ \text { BGC-8 } & 3.088 \pm 0.002 \\ \text { BG-8 } & 2.956 \pm 0.003 \\ \text { CGC-9 } & 3.105 \pm 0.003 \\ \text { CGC-HMI } & 3.122 \pm 0.004 \\ \text { FGC-9 } & 4.153 \pm 0.010 \\ \text { FGC-M4 } & 4.309 \pm 0.016\end{array}$




\section{$\underline{\text { LEACHING }}$}

Consistent leach procedures were used throughout this study to allow for intrastudy comparison of chemical durability. The methods used were similar to those proposed by the Materials Characterization Center's (MCC) static leach test procedure. The major deviation from recommen'ded procedure was the use of polypropylene containers in an oil bath instead of Teflon ${ }^{\circledR}$ containers in an oven. In addition, at the time testing began, the procedure outlined by MCC was in draft form and has since been modified to accomodate new or improved methods. Therefore, caution must be exercised in referring to the methods reported herein as standard MCC procedure.

Eight waste forms were tested to compare the chemical durability of the various glass ceramic waste forms. Each material was produced in the form of rectangular bars nominally $19 \mathrm{~mm}$ by $19 \mathrm{~mm}$ by $75 \mathrm{~mm}$. Leach samples were cut from the bars using a low-speed saw with a diamond impregnated wafering blade. Isopropyl alcohol was used as the lubricating/cooling medium. The sample size was consistent for all materials with dimensions of $10 \mathrm{~mm} \times 10 \mathrm{~mm} \times 4.8 \mathrm{~mm}$ resulting in a sample surface area of $392 \mathrm{~mm}^{2}$. After cutting, the samples were cleaned in acetone followed by three cleanings in ethanol with ultrasonic agitation.

The samples were suspended by monofilament polypropylene and placed in polypropylene bottles. One of two solutions-deionized water, or silicate water--was added to the bottles to achieve a sample surface area to solution volume ratio of $10 \mathrm{~m}^{-1}$. The bottles were then sealed and placed in a bath operating at $90^{\circ} \mathrm{C} \pm 1^{\circ} \mathrm{C}$. Nine samples of each waste form were tested with times of $3,7,14$, and 28 days. One sample was leached at the shorter times, while three samples were leached for 28 days in each of the two solutions. In addition, bottles containing only solution were prepared as above and tested for 28 days under identical conditions as the samples.

After the allotted leaching time, the bottles were removed from the bath and the samples removed and rinsed with deionized water. The bottle was recapped and the solution allowed to cool to room temperature after which

Teflon ${ }^{\circledR}$ is a registered trademark of E.I. duPont de Nemours Co., Inc. 
point the leachate $\mathrm{pH}$ was measured. If the liquid level had changed during testing, the container was filled to its original volume with the appropriate starting solution. A normal loss was $<5 \%$ of original volume after 28 days of testing.

The solutions were analyzed for cations using inductively-coupled plasma emission spectroscopy (ICP) with the detection limits listed in Table 2. Cesium was analyzed by atomic adsorption (AA) with a detection limit of $0.05 \mathrm{ppm}$. 



\section{RESULTS}

The results from the static leach tests are reported in units of "grams of waste form" based on specific elements measured. Thus, the data are normalized to reflect the initial fraction of individual elements present in the material. Results are calculted with the following equation:

$$
\left(N L_{i}\right)=\frac{m_{i}}{f_{i} \cdot S A}
$$

where $(N L)_{j}=$ the normalized mass of element " $i$ " lost per unit surface area of the sample $\left(\mathrm{g} / \mathrm{m}^{2}\right)$

$m_{i}=$ the mass of element " $i$ " in solution at the end of the exper $i$ ment $(g)$

$f_{i}=$ the mass fraction of element " $i$ " in the sample when the exper $i$ ment began (unitless)

$S A=$ surface area of the sample $\left(\mathrm{m}^{2}\right)$

Standard deviations were calculated from data of triplicate samples leached for 28 days.

\section{LEACHING RESULTS}

Basalt Glass Ceramics

Three glass ceramics prepared with Pomona basalt and 20 wt\% PW-9 calcine (BGC-9), PW-4b-7 calcine (BGC-4), or PW-8a-2 calcine (BGC-8) were tested under conditions outlined above. In addition, a vitreous material containing 20 wt\% PW-8a-2 calcine (BG-8) was tested to assess the effect of crystallization on chemical durability.

Tables 5, 6, 7, and 8 show results of the basalt-based products leached at $90^{\circ} \mathrm{C}$ for 3 to 28 days in deionized water and for 28 days in silicate water. The values for 28 days are averages of three replicate samples. The normalized elemental losses of all species leached from the three glass ceramic materials are very low $\left(<3 \mathrm{~g} / \mathrm{m}^{2}\right)$ with the most leachable ion being sodium. The use of 
TABLE 5. Normalized Elemental Losses $\left(\mathrm{NL}_{i}\right)$ for $\mathrm{BGC}-9$ Leached at $90^{\circ} \mathrm{C}$

\begin{tabular}{|c|c|c|c|c|c|c|c|c|c|c|}
\hline \multirow[b]{2}{*}{ Time, $d$} & \multicolumn{9}{|c|}{ Deionized Water as Leachant, $\mathrm{g} / \mathrm{m}^{2}$} & \multirow[b]{2}{*}{$\mathrm{pH}$} \\
\hline & A7 & $\mathrm{Ba}$ & $\mathrm{Ca}$ & $\mathrm{Mg}$ & Mo & $\mathrm{Na}$ & $\mathrm{Si}$ & $\mathrm{Sr}$ & CS & \\
\hline 3 & 0.33 & 0.30 & $-(a)$ & - & - & - & 0.26 & 0.21 & - & 5.63 \\
\hline 7 & 0.50 & 0.60 & - & - & - & - & 0.42 & 0.42 & 0.49 & 4.62 \\
\hline 14 & - & 1.06 & 0.49 & 0.55 & 0.56 & 1.52 & 0.79 & 0.85 & 1.21 & 4.30 \\
\hline 28 & 0.07 & 1.56 & 0.62 & 0.40 & 1.14 & 1.97 & 1.25 & 1.28 & 1.48 & 3.92 \\
\hline$\sigma^{(b)}$ & +0.12 & \pm 0.23 & \pm 0.07 & +0.11 & +0.04 & +0.18 & \pm 0.03 & \pm 0.23 & +0.20 & \pm 0.03 \\
\hline
\end{tabular}

\begin{tabular}{|c|c|c|c|c|c|c|c|c|c|}
\hline \multirow[b]{2}{*}{ Time, d } & \multicolumn{8}{|c|}{ Silicate Water as Leachant, $\mathrm{g} / \mathrm{m}^{2}$} & \multirow[b]{2}{*}{$\mathrm{pH}$} \\
\hline & Al & $\mathrm{Ba}$ & $\mathrm{Ca}$ & $\mathrm{Mg}$ & Mo & $\mathrm{Si}$ & $S r$ & Cs & \\
\hline & 1.50 & 1.21 & 0.17 & - & 1.67 & 1.44 & 1.27 & 1.59 & 7.71 \\
\hline$\sigma^{(b)}$ & \pm 0 & \pm 0 & \pm 0 & & \pm 0 & \pm 0.06 & \pm 0 & \pm 0.05 & \pm 0.02 \\
\hline
\end{tabular}

(a) Concentration in solution was below the detection limit.

(b) $\sigma=$ one standard deviation from average of data of triplicate samples leached for 28 days.

TABLE 6. Normalized Elemental Losses $\left(\mathrm{NL}_{j}\right)$ for $\mathrm{BGC}-4$ Leached at $90^{\circ} \mathrm{C}$

\begin{tabular}{|c|c|c|c|c|c|c|c|c|c|c|}
\hline \multirow[b]{2}{*}{ Time, $d$} & \multicolumn{9}{|c|}{ Deionized Water as Leachant, $\mathrm{g} / \mathrm{m}^{2}$} & \multirow[b]{2}{*}{$\mathrm{pH}$} \\
\hline & Al & $\mathrm{Ba}$ & $\mathrm{Ca}$ & $\mathrm{Mg}$ & Mo & $\mathrm{Na}$ & $\mathrm{Si}$ & $\mathrm{Sr}$ & Cs & \\
\hline 3 & $-(a)$ & - & 0.06 & - & 0.18 & 0.53 & 0.09 & 0.13 & 0.14 & 4.98 \\
\hline 7 & - & 0.29 & 0.12 & - & 0.28 & 0.74 & 0.22 & 0.30 & - & 4.31 \\
\hline 14 & 0.09 & 0.45 & 0.16 & 0.42 & 0.38 & 1.38 & 0.33 & 0.43 & 0.36 & 4.13 \\
\hline 28 & 0.07 & 1.02 & 0.59 & 0.46 & 0.65 & 1.54 & 0.82 & 0.84 & 0.86 & 3.98 \\
\hline$\sigma^{(b)}$ & \pm 0.13 & \pm 0.07 & +0.08 & \pm 0.10 & +0.04 & +0.94 & +0.08 & +0.15 & +0.19 & \pm 0.05 \\
\hline
\end{tabular}

\begin{tabular}{|c|c|c|c|c|c|c|c|c|c|}
\hline \multirow[b]{2}{*}{ ime, $\mathrm{d}$} & \multicolumn{8}{|c|}{ Silicate Water as Leachant, $\mathrm{g} / \mathrm{m}^{2}$} & \multirow[b]{2}{*}{$\mathrm{pH}$} \\
\hline & A1 & $\mathrm{Ba}$ & $\mathrm{Ca}$ & $\mathrm{Mg}$ & Mo & $\mathrm{Si}$ & $S r$ & Cs & \\
\hline & 1.10 & 0.65 & 0.21 & - & 1.46 & 1.26 & 1.09 & 1.17 & 7.77 \\
\hline$\sigma^{(b)}$ & +0 & +0.41 & +0.09 & & +0.36 & +0.03 & +0.14 & +0.04 & +0.03 \\
\hline
\end{tabular}

(a) Concentration in solution was below the detection limit.

(b) $\sigma=$ one standard deviation from average of data of triplicate samples leached for 28 days. 
TABLE 7. Normalized Elemental Losses $\left(\mathrm{NL}_{j}\right)$ for BGC-8 Leached at $90^{\circ} \mathrm{C}$

\begin{tabular}{|c|c|c|c|c|c|c|c|c|c|c|}
\hline \multirow[b]{2}{*}{ Time, d } & \multicolumn{9}{|c|}{ Deionized Water as Leachant, $\mathrm{g} / \mathrm{m}^{2}$} & \multirow[b]{2}{*}{$\mathrm{pH}$} \\
\hline & A1 & $\mathrm{Ba}$ & $\mathrm{Ca}$ & $\mathrm{Mg}$ & Mo & $\mathrm{Na}$ & $\mathrm{Si}$ & $\mathrm{Sr}$ & Cs & \\
\hline 3 & $-(a)$ & 0.26 & 0.08 & - & 0.47 & 1.08 & 0.25 & 0.32 & 0.33 & 5.40 \\
\hline 7 & - & 0.67 & 0.19 & - & 0.40 & 1.66 & 0.46 & 0.65 & - & 4.25 \\
\hline 14 & 0.05 & 1.12 & 0.30 & 0.30 & 0.66 & 2.56 & 0.75 & 0.97 & 0.98 & 4.15 \\
\hline 28 & 0.05 & 1.66 & 0.60 & 0.42 & 0.42 & 2.87 & 1.28 & 1.29 & 1.47 & 4.06 \\
\hline$\sigma^{(b)}$ & \pm 0.08 & \pm 0.30 & +0.07 & \pm 0.16 & +0.72 & +0.73 & \pm 0.16 & \pm 0.37 & +0.16 & \pm 0.03 \\
\hline
\end{tabular}

\begin{tabular}{|c|c|c|c|c|c|c|c|c|c|}
\hline \multirow[b]{2}{*}{ Time, $d$} & \multicolumn{8}{|c|}{ Silicate Water as Leachant, $\mathrm{g} / \mathrm{m}^{2}$} & \multirow[b]{2}{*}{$\mathrm{pH}$} \\
\hline & A] & $\mathrm{Ba}$ & $\mathrm{Ca}$ & $\mathrm{Mg}$ & Mo & $\mathrm{Si}$ & $S r$ & Cs & \\
\hline & 1.17 & 0.99 & - & 0.04 & - & 1.26 & 1.08 & 1.31 & 7.85 \\
\hline$\sigma^{(b)}$ & +0 & \pm 0.21 & & \pm 0.02 & & \pm 0.11 & \pm 0 & to & \\
\hline
\end{tabular}

(a) Concentration in solution was below the detection limit.

(b) $\sigma=$ one standard deviation from average of data of triplicate samples leached for 28 days.

TABLE 8. Normalized Elemental Losses $\left(\mathrm{NL}_{j}\right)$ for $\mathrm{BG}-8$ Leached at $90^{\circ} \mathrm{C}$

\begin{tabular}{|c|c|c|c|c|c|c|c|c|c|c|}
\hline \multirow[b]{2}{*}{ Time, $d$} & \multicolumn{9}{|c|}{ Deionized Water as Leachant, $\mathrm{g} / \mathrm{m}^{2}$} & \multirow[b]{2}{*}{$\mathrm{pH}$} \\
\hline & AT & $\mathrm{Ba}$ & $\mathrm{Ca}$ & $\mathrm{Mg}$ & Mo & $\mathrm{Na}$ & $\mathrm{Si}$ & $\mathrm{Sr}$ & CS & \\
\hline 3 & 0.12 & 2.01 & 0.52 & 0.27 & 1.25 & 3.69 & 1.46 & 1.72 & 1.47 & 7.13 \\
\hline 7 & $-(a)$ & 2.01 & 2.29 & 1.93 & 2.18 & 2.35 & 2.29 & 2.31 & 1.96 & 6.79 \\
\hline 14 & - & 3.31 & 3.29 & 2.80 & 2.70 & 3.41 & 3.32 & 3.33 & 2.61 & 5.50 \\
\hline 28 & - & 4.19 & 5.66 & 4.25 & 2.58 & 3.81 & 4.50 & 4.00 & 3.37 & 4.92 \\
\hline$\sigma^{(b)}$ & & +0.17 & +1.02 & +0.46 & \pm 0.11 & +0.58 & \pm 0.18 & +0.40 & +0.09 & +0.14 \\
\hline
\end{tabular}

\begin{tabular}{|c|c|c|c|c|c|c|c|c|c|}
\hline & \multicolumn{3}{|c|}{ Silicate } & \multicolumn{5}{|c|}{ or as Leachant, $\mathrm{g} / \mathrm{m}^{2}$} & \multirow[b]{2}{*}{$\mathrm{pH}$} \\
\hline & AT & $\mathrm{Ba}$ & $\mathrm{Ca}$ & $\mathrm{Mg}$ & Mo & $\mathrm{Si}$ & $S r$ & Cs & \\
\hline 28 & 1.76 & 0.50 & 1.76 & 1.51 & 2.52 & 2.03 & 1.61 & 1.63 & 7.94 \\
\hline & \pm 0 & \pm 0.21 & \pm 0 & \pm 0.13 & \pm 0 & \pm 0.13 & \pm 0 & \pm 0 & \pm 0.12 \\
\hline
\end{tabular}

(a) Concentration in solution was below the detection limit.

(b) $\sigma=$ one standard deviation from average of data of triplicate samples leached for 28 days. 
different simulated calcine powders had a minimal effect on chemical durability as the results show. Of the basalt glass ceramics, BGC-4 demonstrated the lowest normalized elemental losses-less than $2 \mathrm{~g} / \mathrm{m}^{2}$ for any element analyzed after 28 days of leaching.

The effect of crystallization on leachability is seen by comparing the data in Tables 7 and 8 . The first shows results of BGC- 8 and the second the results of its vitreous counterpart (BG-8), i.e., the same material before crystallization. A decrease in leachability of all elements was noted for the glass ceramic. The largest decreases were observed for those elements present in the predominant crystalline phases. The release of calcium and magnesium after 28 days, for example, decreased by factors of 9 and 10, respectively after recrystallization. Similarly, the formation of powellite (Ca, $\mathrm{Sr}) \mathrm{MoO}_{4}$ resulted in strontium and molybdenum releases 3 and 6 times lower from the glass ceramic.

Tables 5 through 8 also present results of the basalt-based products leached for 28 days in silicate water. Comparing the results of the glass ceramics with those from deionized water shows very little difference except for small increases in aluminum and molybdenum releases and decreases in the release of calcium and magnesium. The results for BG-8, however, show a marked decrease in leachability for silicate water for all elements except aluminum which was slightly higher, and for molybdenum which remained the same. The greatest difference was observed for barium which decreased by a factor of 8 over deionized water.

Celsian Glass Ceramics

Tables 9 and 10 show the results of leaching two celsian glass ceramics at $90^{\circ} \mathrm{C}$ for 3 to 28 days. The values at 28 days are the average of three samples. The normalized elemental losses of barium and silicon are lowest of those elements considered, supporting the premise that crystalline phases are more durable than the residual glass in these products. The main crystalline phase produced in these materials is a celsian $\left(\mathrm{BaAl}_{2} \mathrm{Si}_{2} \mathrm{O}_{8}\right)$ phase. Comparing the results of the two CGC's indicates no major differences in chemical durability with differing waste calcines. 
TABLE 9. Normalized Elemental Losses $\left(\mathrm{NL}_{j}\right)$ for CGC-9 Leached at $90^{\circ} \mathrm{C}$

\begin{tabular}{|c|c|c|c|c|c|c|c|c|c|c|}
\hline \multirow[b]{2}{*}{ Time, $d$} & \multicolumn{9}{|c|}{ Deionized water as Leachant, $\mathrm{g} / \mathrm{m}^{2}$} & \multirow[b]{2}{*}{$\mathrm{pH}$} \\
\hline & $B$ & $\overline{B a}$ & $\mathrm{Ca}$ & $\mathrm{Mg}$ & Mo & $\mathrm{Si}$ & $\mathrm{Sr}$ & $\mathrm{Cs}$ & $\mathrm{Li}$ & \\
\hline 3 & 7.3 & 3.2 & 5.4 & 5.4 & 13.6 & 4.3 & 6.4 & 7.1 & 8.8 & 7.76 \\
\hline 7 & 9.5 & 3.8 & 7.9 & 10.8 & 17.0 & 4.7 & 8.3 & 8.4 & 12.0 & 7.57 \\
\hline 14 & 14.5 & 4.2 & 10.8 & 10.0 & 21.2 & 6.4 & 11.6 & 6.5 & 17.4 & 7.75 \\
\hline 28 & 21.8 & 5.3 & 16.8 & 14.4 & 27.6 & 7.5 & 16.4 & 18.8 & 30.3 & 6.95 \\
\hline$\sigma^{(a)}$ & \pm 0.6 & \pm 0.2 & \pm 0.4 & \pm 0.8 & \pm 1.2 & \pm 0.2 & \pm 0.5 & +0.6 & \pm 0.8 & +0.16 \\
\hline
\end{tabular}

Silicate Water as Leachant, $\mathrm{g} / \mathrm{m}^{2}$

\begin{tabular}{|c|c|c|c|c|c|c|c|c|c|}
\hline ime, d & $B$ & $\mathrm{Ba}$ & $\mathrm{Ca}$ & $\mathrm{Mg}$ & Mo & $S r$ & $\overline{C S}$ & $\mathrm{Li}$ & $\mathrm{pH}$ \\
\hline \multirow{2}{*}{$\begin{array}{l}28 \\
\sigma(a)\end{array}$} & 6 & 1.0 & 4.0 & 5.5 & 12.5 & 4.4 & 6.9 & 8.8 & 7.78 \\
\hline & \pm 0.6 & \pm 0.1 & \pm 0.2 & \pm 0 & +1.5 & \pm 0.3 & \pm 1.3 & \pm 0.7 & \pm 0.02 \\
\hline
\end{tabular}

(a) $\sigma=$ one standard deviation from average of data of triplicate samples leached for 28 days.

TABLE 10. Normalized Elemental Losses $\left(\mathrm{NL}_{\mathfrak{j}}\right)$ for CGC-HMI Leached at $90^{\circ} \mathrm{C}$

\begin{tabular}{|c|c|c|c|c|c|c|c|c|c|c|}
\hline \multirow[b]{2}{*}{ Time, $d$} & \multicolumn{10}{|c|}{ Deionized Water as Leachant, $\mathrm{g} / \mathrm{m}^{2}$} \\
\hline & $\mathrm{B}$ & $\mathrm{Ba}$ & $\mathrm{Ca}$ & $\mathrm{Mg}$ & Mo & $\mathrm{Si}$ & $S r$ & Cs & $\mathrm{Li}$ & $\mathrm{pH}$ \\
\hline 3 & 7.9 & 2.9 & 5.5 & 6.4 & 12.7 & 4.4 & 7.5 & 8.1 & 8.8 & 7.89 \\
\hline 7 & 10.8 & 3.7 & 8.5 & 12.3 & 15.8 & 5.0 & 10.1 & 10.8 & 13.0 & 7.79 \\
\hline 14 & 13.8 & 3.7 & 9.7 & 10.2 & 16.9 & 5.9 & 12.1 & 7.7 & 16.5 & 7.76 \\
\hline 28 & 19.8 & 4.7 & 14.3 & 15.2 & 21.7 & 6.5 & 16.4 & 19.0 & 26.4 & 7.01 \\
\hline$\sigma(a)$ & \pm 0.2 & \pm 0.2 & \pm 0.2 & \pm 0.5 & \pm 0.4 & \pm 0.1 & \pm 0.4 & +0.9 & \pm 1.0 & \pm 0.11 \\
\hline
\end{tabular}

Silicate Water as Leachant, $\mathrm{g} / \mathrm{m}^{2}$

\begin{tabular}{|c|c|c|c|c|c|c|c|c|c|}
\hline ne, $d$ & $\bar{B}$ & $\mathrm{Ba}$ & $\mathrm{Ca}$ & $\mathrm{Mg}$ & Mo & $\mathrm{Sr}$ & Cs & $\mathrm{Li}$ & $\mathrm{pH}$ \\
\hline & & 1.2 & 4. & 7.1 & 14.6 & 6.3 & 9.2 & 11.7 & 7.91 \\
\hline & \pm 0.7 & \pm 0 & \pm 0.4 & \pm 0 & +0.4 & +0.3 & \pm 0.8 & \pm 0.6 & +0.03 \\
\hline
\end{tabular}

(a) $\sigma=$ one standard deviation from average of data of triplicate samples leached for 28 days. 
The leachability of celsian glass ceramics improves when tested in silicate water as shown by comparison of Tables 9 and 10 . The improvement over deionized water is more noticeable for CGC-9 with the normalized elemental losses lower by a factor of 2 for molybdenum and by a factor of 5 for barium. The relative order is the same for CGC-HMI although the magnitudes are slightly lower, ranging from a 1.5 times improvement for molybdenum to 3.8 for barium.

\section{Fresnoite Glass Ceramics}

The normalized elemental losses for the two fresnoite glass ceramics (FGC-9 and FGC-M4) are shown in Tables 11 and 12. The major crystalline phases in these materials are fresnoite $\left(\mathrm{Ba}_{2} \mathrm{TiSi}_{2} \mathrm{O}_{8}\right)$, scheelite $\left(\mathrm{BaMoO}_{4}\right)$, and perovskite $\mathrm{Ca}\left(\mathrm{R} . \mathrm{E} ., \mathrm{Ti} \mathrm{O}_{3}\right.$. Although fresnoite is the major phase, the amount of barium and silicon in solution after 28 days $\left(12.6\right.$ and $11 \mathrm{~g} / \mathrm{m}^{2}$ ) raises the question as to whether these elements are sufficiently immobilized in a durable phase. Scheelite appears to have a beneficial effect on product quality since the amount of molybdenum leached is relatively small. The type of waste incorporated in fresnoite glass ceramics does not affect the leachability to a great extent except for cesium which leaches twice as much from FGC-M4.

TABLE 11. Normalized Elemental Losses $\left(\mathrm{NL}_{j}\right)$ for $\mathrm{FGC}-9$ Leached at $90^{\circ} \mathrm{C}$

\begin{tabular}{|c|c|c|c|c|c|c|c|c|}
\hline \multirow[b]{2}{*}{ Time, $\mathrm{d}$} & \multicolumn{7}{|c|}{ Deionized Water as Leachant, $\mathrm{g} / \mathrm{m}^{2}$} & \multirow[b]{2}{*}{$\mathrm{pH}$} \\
\hline & $\mathrm{Ba}$ & $\mathrm{Mg}$ & Mo & $\mathrm{Na}$ & $\mathrm{Si}$ & $\mathrm{Sr}$ & $\mathrm{Cs}$ & \\
\hline 3 & 1.38 & 0.61 & 5.71 & 3.14 & 1.62 & 0.83 & 2.92 & 7.17 \\
\hline 7 & 3.20 & 1.93 & 7.40 & 5.28 & 3.16 & 2.17 & 4.30 & 6.72 \\
\hline 14 & 5.14 & 1.34 & 5.60 & 6.68 & 5.38 & 3.92 & 6.92 & 6.15 \\
\hline 28 & 12.63 & 4.39 & 2.47 & 10.35 & 11.11 & 9.66 & 10.86 & 5.35 \\
\hline$\sigma^{(a)}$ & \pm 0.27 & \pm 0.28 & \pm 0.31 & \pm 0.34 & \pm 0.25 & \pm 0.34 & \pm 0.32 & \pm 0.03 \\
\hline
\end{tabular}

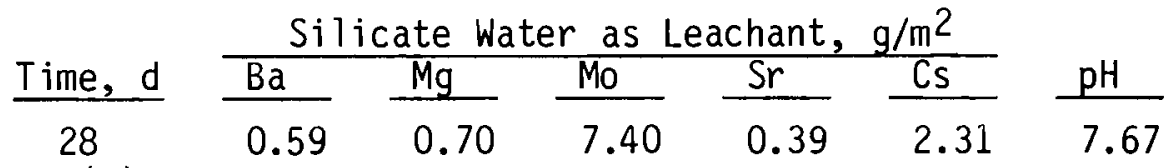

$$
\begin{aligned}
& \sigma(a) \quad \pm 0.03 \pm 0 \quad \pm 0 \quad \pm 0 \quad \pm 0 \quad \pm 0.04
\end{aligned}
$$

(a) $\sigma=$ one standard deviation from average of data of triplicate samples leached for 28 days. 
TABLE 12. Normalized Elemental Losses $\left(\mathrm{NL}_{i}\right)$ for $\mathrm{FGC}-\mathrm{M4}$ Leached at $90^{\circ} \mathrm{C}$

\begin{tabular}{|c|c|c|c|c|c|c|c|c|}
\hline \multirow[b]{2}{*}{ Time, $d$} & \multicolumn{7}{|c|}{ Deionized Water as Leachant, $\mathrm{g} / \mathrm{m}^{2}$} & \multirow[b]{2}{*}{$\mathrm{pH}$} \\
\hline & $\mathrm{Ba}$ & $\mathrm{Mg}$ & Mo & $\mathrm{Na}$ & $\mathrm{Si}$ & $S r$ & Cs & \\
\hline 3 & 1.34 & 1.22 & 5.94 & 3.20 & 1.62 & 0.48 & 3.86 & 6.97 \\
\hline 7 & 2.79 & 2.82 & 6.95 & - & 2.56 & 1.10 & 5.06 & 6.51 \\
\hline 14 & 5.62 & 2.35 & 5.63 & 5.67 & 5.11 & 2.83 & 8.43 & 6.08 \\
\hline 28 & 13.21 & 8.02 & 3.47 & 9.55 & 10.58 & 6.79 & 20.08 & 5.46 \\
\hline$\sigma(a)$ & \pm 0.02 & \pm 0.80 & \pm 1.84 & \pm 1.29 & +0.16 & +0 & +5.02 & +0.05 \\
\hline
\end{tabular}

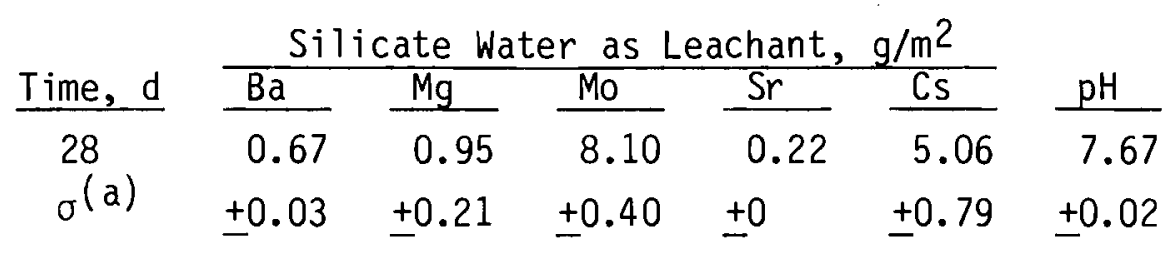

(a) $\sigma=$ one standard deviation from average of data of triplicate samples leached for 28 days.

Using silicate water as a leachant resulted in drastically reduced leach values for all elements except molybdenum which increased by a factor of 3 over deionized water. The normalized elemental losses of barium and strontium decreased by factors 21 and 25 , respectively for FGC-9, while magnesium and cesium decreased by factors of 6 and 5 .

\section{DISCUSSION OF RESULTS}

The main purpose of this study was to assess the relative chemical durability of three glass ceramic systems being developed and tested for immobilization of high-level radioactive waste. Eight materials of the three systems were tested to allow the following comparisons to be evaluated:

- Comparison of leachability of basalt, celsian, and fresnoite glass ceramics incorporating the same simulated high-level waste calcine (BGC-9, CGC-9, FGC-9).

- Comparison of leachability as function of waste composition variations within each system (BGC-9, BGC-4, BGC-8; CGC-9, CGC-HMI; FGC-9, FGC-M4). 
- Comparison of leachability of basalt-based material before and after crystallization (BG-8, BGC-8).

- Comparison of leachability of all materials as a function of leachant type (deionized water, silicate water)

Experimental conditions and procedures were identical for all materials with the only variables being waste form type and leachant type.

Effect of Leaching Time on Normalized Elemental Losses

Normalized elemental losses for all species considered as a function of leaching time are presented in Tables 5 through 12 for the eight waste forms tested. The data are for leaching at $90^{\circ} \mathrm{C}$ in deionized water with a sample surface area to solution volume ratio of $10 \mathrm{~m}^{-1}$. The general trend observed is an increasing loss with time. The rate of elemental losses varies with type of waste form and the specific species as seen in Figures 5, 6, and 7. Figure 5 is a plot of normalized silicon loss from BGC-8, BG-8, CGC-HMI, and FGC-M4. The plot shows the near linear relationship of silicon release versus leaching time from 3 to 28 days for all materials except FGC-M4 which increased dramatically after 14 days. The effect of crystallization on basalt-based materials is also seen in this figure. The release of silicon from BG- 8 increases at a faster rate than $B G C-8$ with the silicon release $3 \mathrm{~g} / \mathrm{m}^{2}$ more after 28 days than after 3 days; the release from $B G C-8$ increased by $1 \mathrm{~g} / \mathrm{m}^{2}$.

Figure 6 shows the normalized strontium release as a function of leaching time for the same four materials. The release from the basalt waste forms follows a trend very similar to silicon release, i.e., a relatively small slope. Celsian and fresnoite glass ceramics, however, demonstrate large increases in strontium release with increasing leaching time. The total differences in strontium release are about the same for both materials between 3 and 28 days, but celsian glass ceramics release $\sim 7 \mathrm{~g} / \mathrm{m}^{2}$ more than fresnoite at all times.

Figure 7 shows normalized cesium release as a function of leaching time for the same materials in the previous two figures. BGC-8 and BG- 8 demonstrate very little time dependency on cesium loss illustrated by the nearly flat 


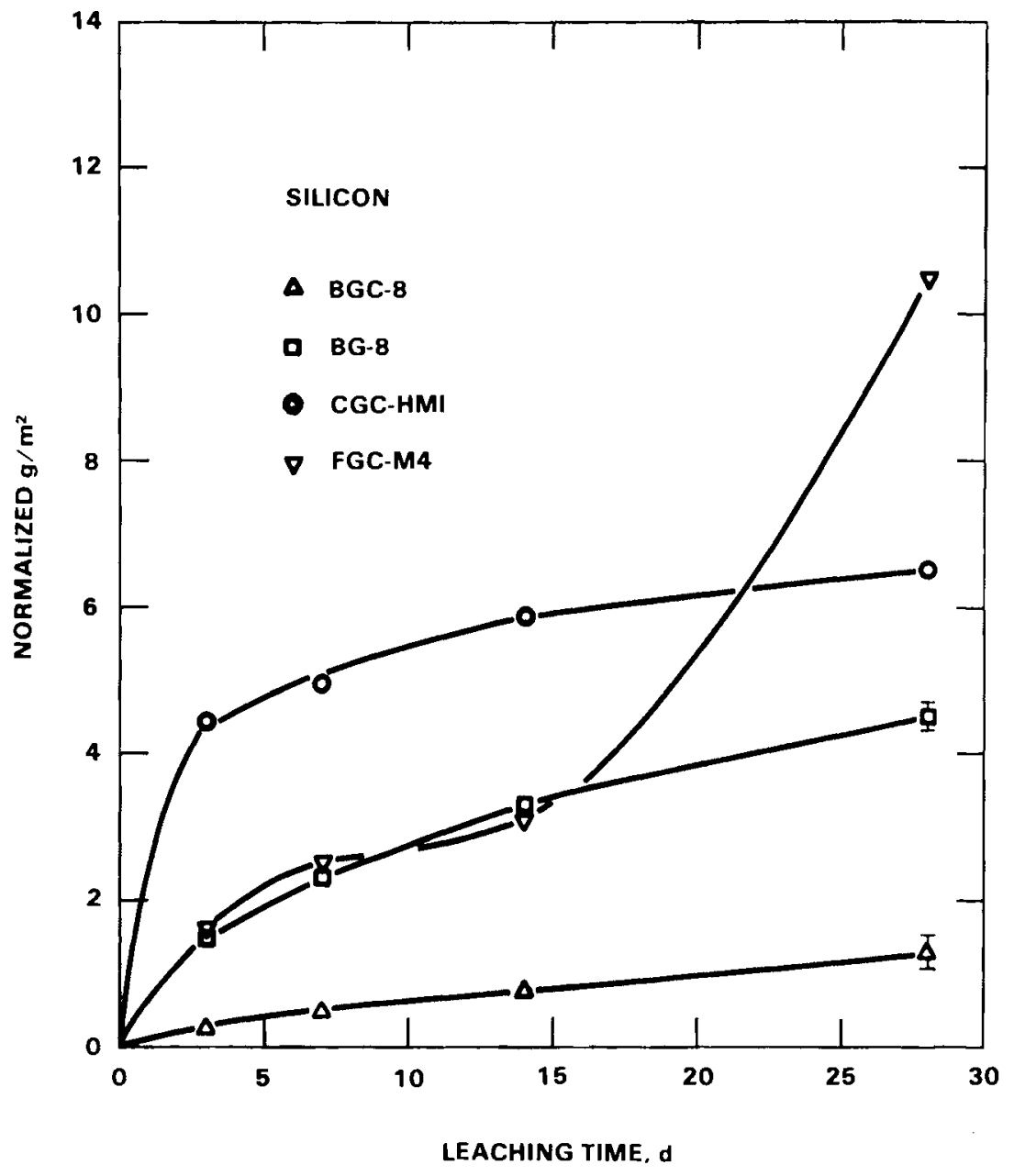

FIGURE 5. Normalized Silicon Loss from Four Waste Forms as a Function of Leaching Time in Deionized Water at $90^{\circ} \mathrm{C}$ 


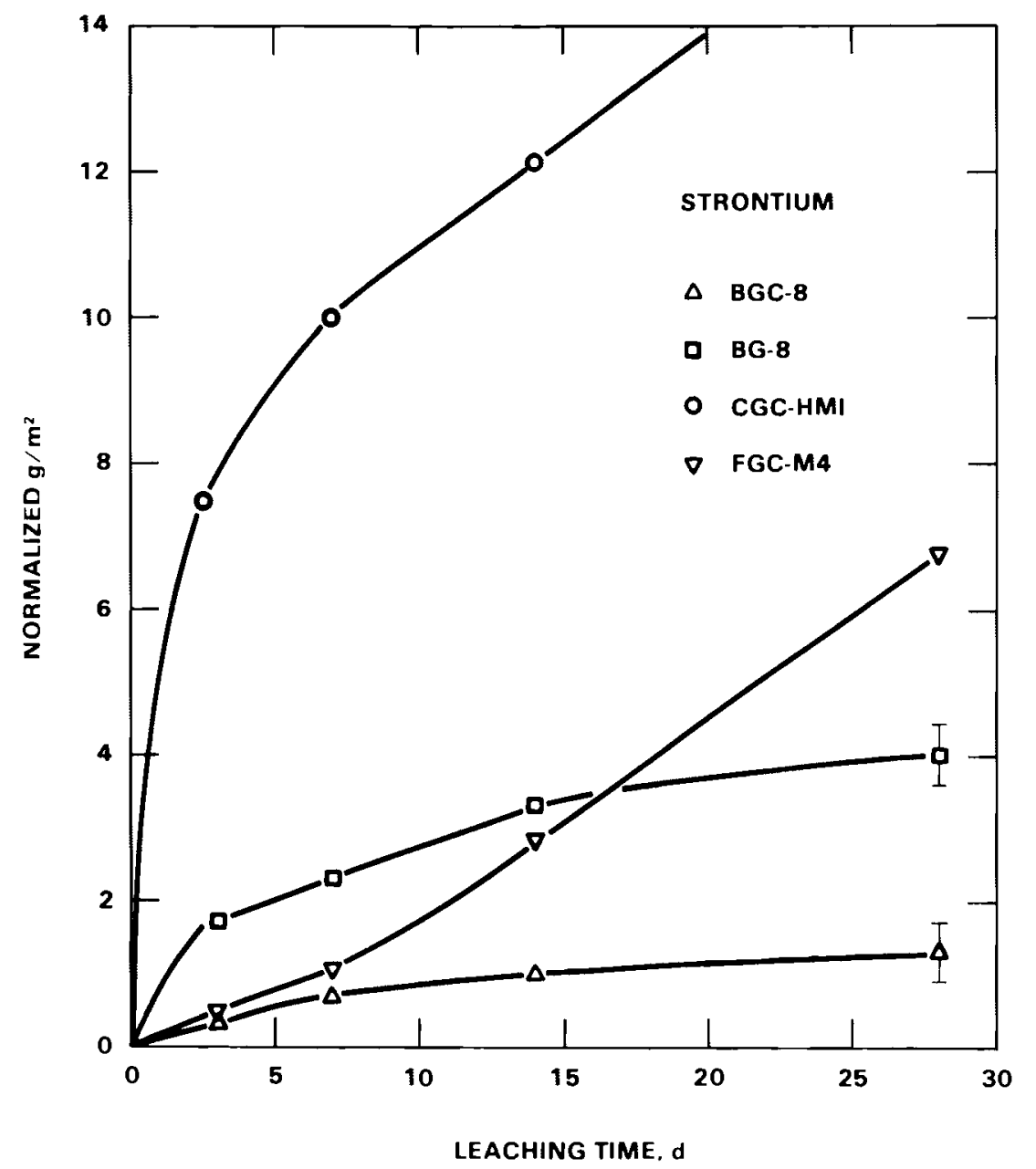

FIGURE 6. Normalized Strontium Loss from Four Waste Forms as a Function of Leaching Time in Deionized Water at $90^{\circ} \mathrm{C}$ 


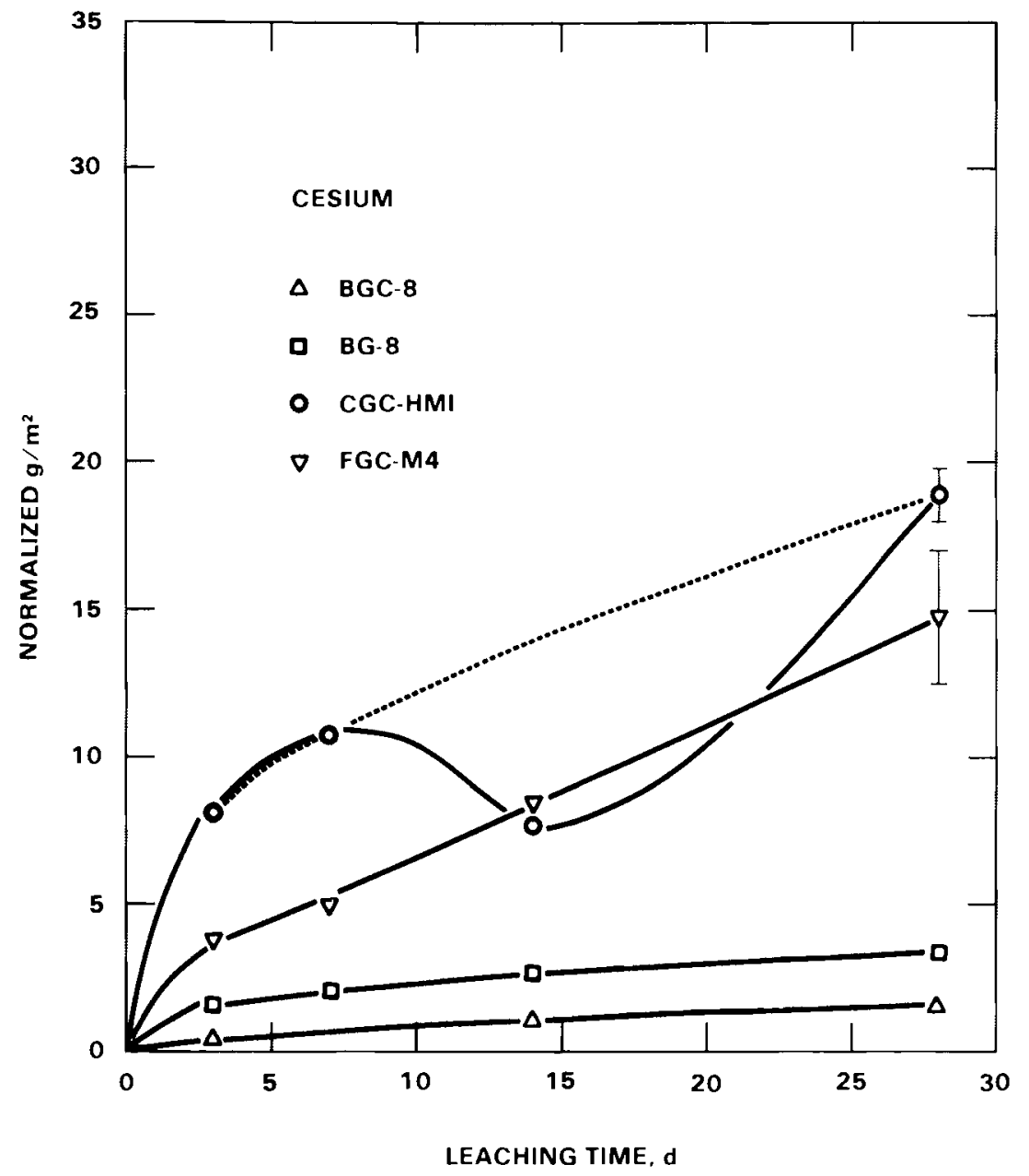

FIGURE 7. Normalized Cesium Loss from Four Waste Forms as a Function of Leaching Time in Deionized water at $90^{\circ} \mathrm{C}$ 
curves. The release from FGC-M4 increases more sharply, ranging from $\sim 4 \mathrm{~g} / \mathrm{m}^{2}$ after 3 days to $15 \mathrm{~g} / \mathrm{m}^{2}$ after 28 days. Cesium release from CGC-HMI follows an interesting relationship with time as noted by the solid line in Figure 7 . However, the data at 14 days may be erroneous; the dashed line represents a more realistic relationship neglecting the 14-day point.

The effect of leaching time on leachate $\mathrm{pH}$ values is seen in Tables 5-12 for the eight waste forms tested. The values presented for 28 days are averages of three samples with an average standard deviation for all samples of 0.06 . The $\mathrm{pH}$ of all the leachates decreased with leaching time after 3 days. The initial pH of the deionized water was 5.4. Figure 8 graphically illustrates the time dependency of leachate $\mathrm{pH}$ for four selected waste forms. As seen in the figure the $\mathrm{pH}$ of the $\mathrm{BGC}-9$ leachate decreases rapidly between 3 and 7 days and less rapidly thereafter. BG-8 leachate $\mathrm{pH}$ shows the most rapid decrease between 7 and 14 days. CGC-HMI leachate pH demonstrates the smallest time dependency with $\mathrm{pH}$ values nearly linear with time from 3 to 14 days, followed by a decrease from 7.76 to 7.01 between 14 and 28 days. The pH of FGC-M4 leachate follows a smooth relationship with time decreasing from 7 to 5.5 from 3 to 28 days.

Figures 9 through 13 provide an easy means of comparison of the eight waste forms tested for relative normalized elemental losses of five elements common to all materials. The figures illustrate normalized elemental losses after leaching for 28 days at $90^{\circ} \mathrm{C}$ in deionized water. The values plotted are averages of three replicate samples with standard deviations shown in Tables 5-12.

Figure 9 compares the normalized barium release from the eight waste forms leached for 28 days at $90 \mathrm{C}$ in deionized water. Basalt glass ceramics demonstrate the lowest release of all materials with values $<2 \mathrm{~g} / \mathrm{m}^{2}$. BG-8 released 22.5 times more barium than $B G C-8$ probably due to the incorporation of barium in a more stable crystalline phase in the latter material. Celsian glass ceramics retain barium relatively we11, as predicted by its designed crystalline phases with the major phase being a celsian type $\left(\mathrm{BaAl}_{2} \mathrm{Si}_{2} \mathrm{O}_{8}\right)$. Fresnoite glass ceramics are the poorest of the materials in barium retention, releasing $\sim 13 \mathrm{~g} / \mathrm{m}^{2}$. 


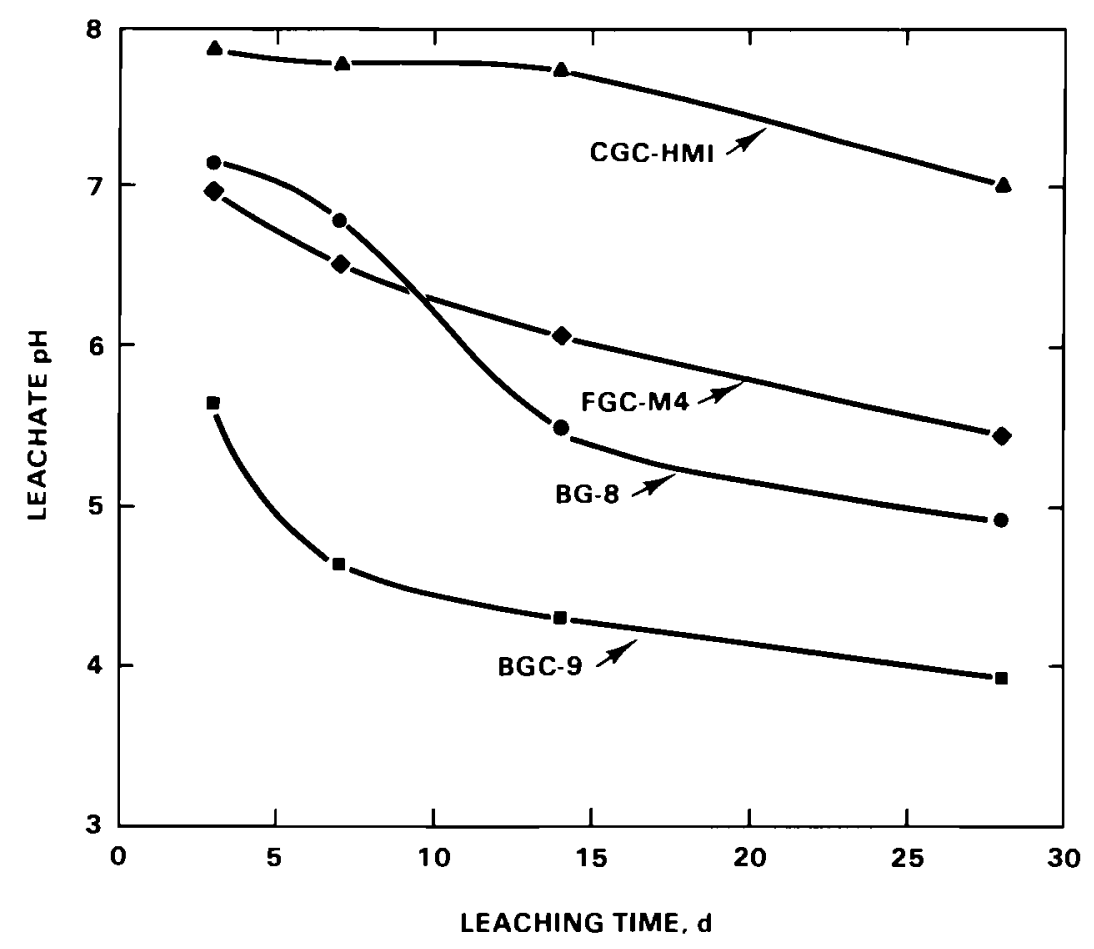

FIGURE 8. Leachate pH as a Function of Leaching Time for Four Waste Forms After Leaching at $90^{\circ} \mathrm{C}$ in Deionized Water

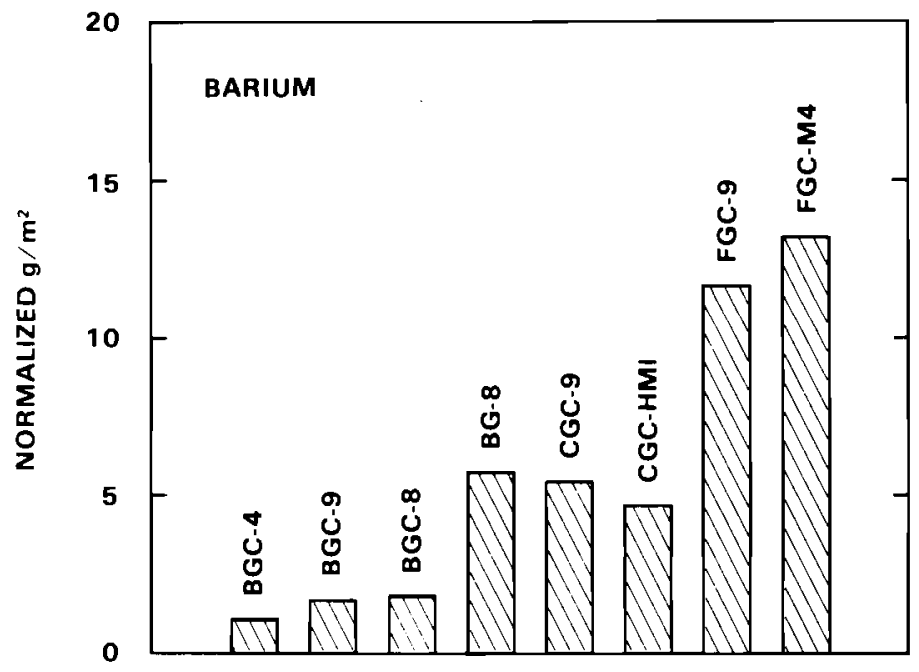

FIGURE 9. Comparison of Normalized Barium Release from Glass Ceramics After Leaching for 28 Days at $90^{\circ} \mathrm{C}$ in Deionized Water 


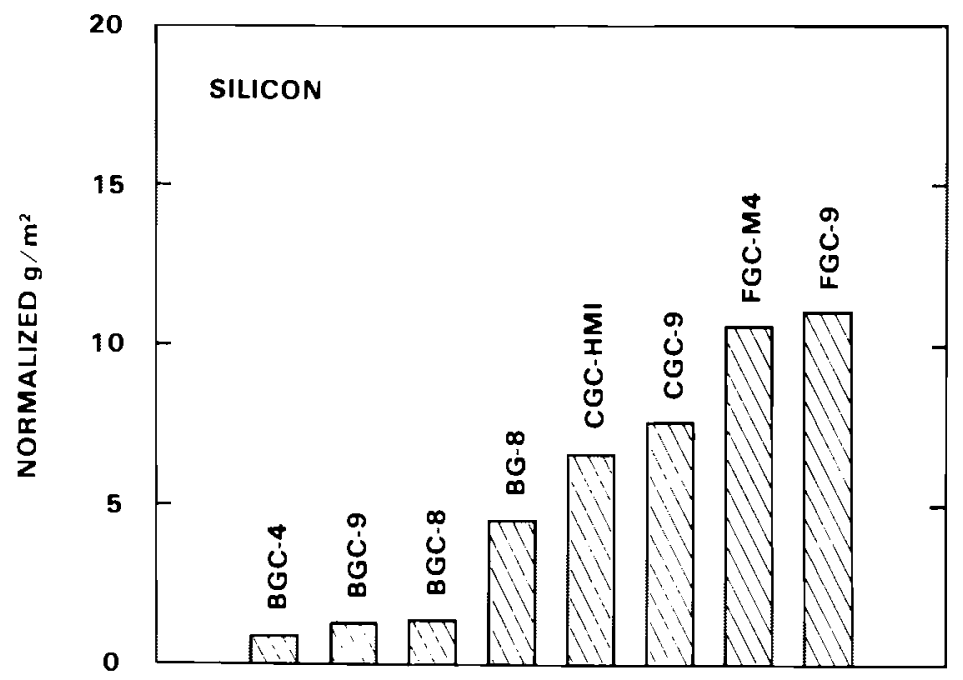

FIGURE 10. Comparison of Normalized Silicon Release from Glass Ceramics After Leaching for 28 Days at $90^{\circ} \mathrm{C}$ in Deionized Water

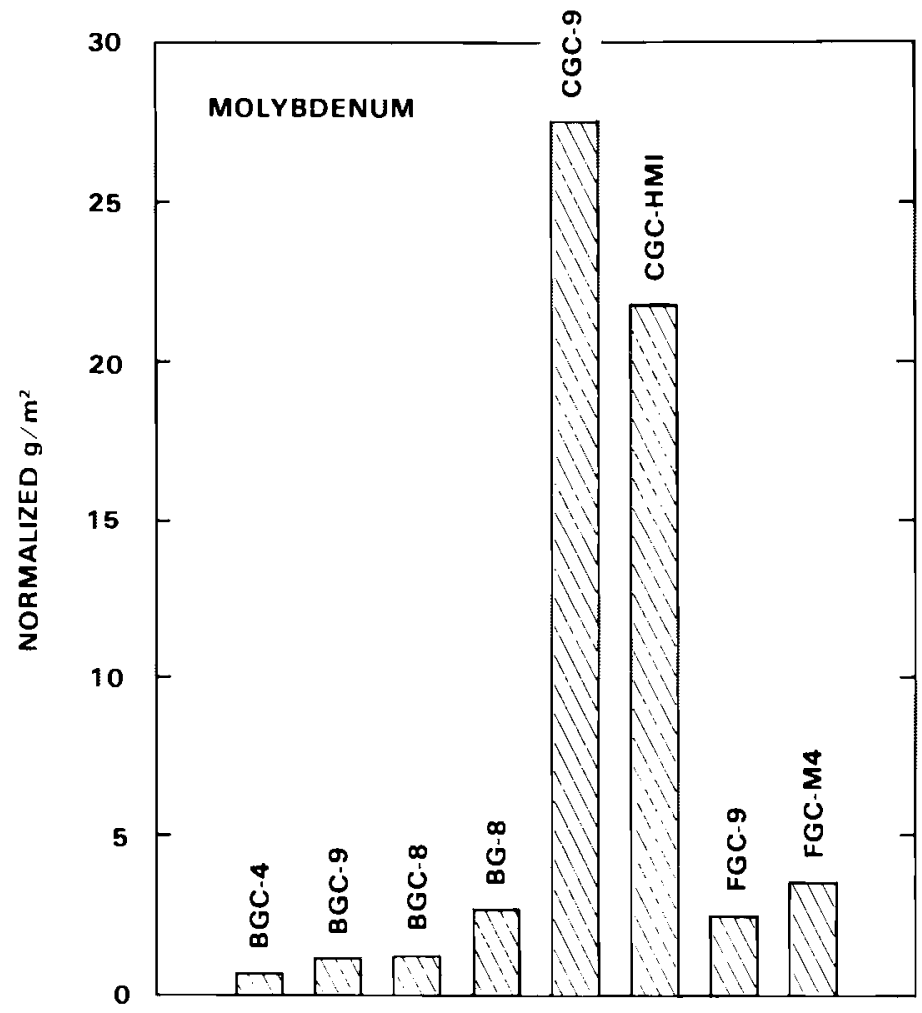

FIGURE 11. Comparison of Normalized Molybdenum Release from Glass Ceramics After Leaching for 28 Days at $90^{\circ} \mathrm{C}$ in Deionized Water 


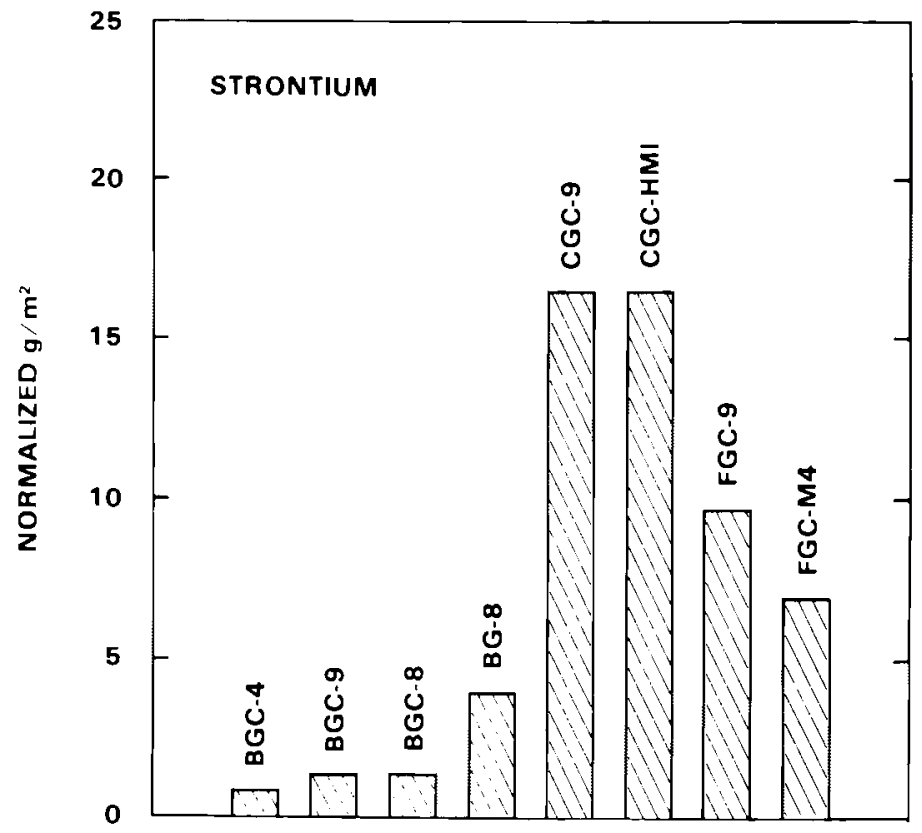

FIGURE 12. Comparison of Normalized Strontium Release from Glass Ceramics After Leaching for 28 Days at $90^{\circ} \mathrm{C}$ in Deionized Water

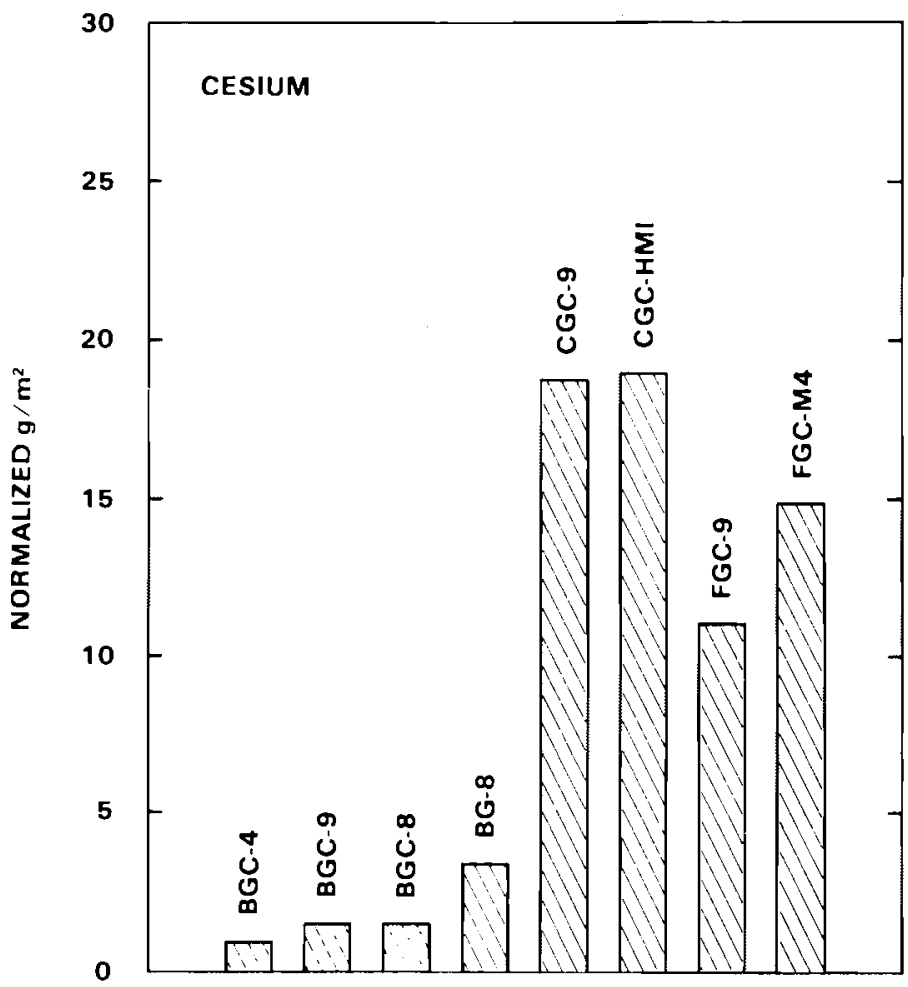

FIGURE 13. Comparison of Normalized Cesium Release from Glass Ceramics After Leaching for 28 Days at $90^{\circ} \mathrm{C}$ in Deionized Water 
Normalized silicon release from the waste forms is seen in Figure 10. Again, the basalt glass ceramics have the lowest silicon release $\left(<1.3 \mathrm{~g} / \mathrm{m}^{2}\right)$, which corresponds to a 3.5 times improvement over the release from the uncrystallized material (BG-8). Celsian and fresnoite demonstrate silicon releases of $\sim 7$ and $11 \mathrm{~g} / \mathrm{m}^{2}$, respectively.

Figure 11 shows the normalized release of molybdenum from the eight waste forms. Molybdenum is retained relatively well in all materials except celsian glass ceramics. CGC-9 demonstrates the worst retention of molybdenum releasing $\sim 28 \mathrm{~g} / \mathrm{m}^{2}$ with CGC-HMI slightly better at $22 \mathrm{~g} / \mathrm{m}^{2}$. The basalt products and fresnoite glass ceramics released $<3.5 \mathrm{~g} / \mathrm{m}^{2}$.

Figures 12 and 13 compare the normalized releases of strontium and cesium from the eight waste forms. The same trend is evidenced in the release from the basalt-based materials with losses of both elements less than $1.5 \mathrm{~g} / \mathrm{m}^{2}$ from the glass ceramics and less than $4 \mathrm{~g} / \mathrm{m}^{2}$ from $B G-8$. The release of strontium and cesium from the two celsian glass ceramics appears to be unaffected by waste stream. Each released $\sim 16.4 \mathrm{~g} / \mathrm{m}^{2}$ of strontium and $\sim 19 \mathrm{~g} / \mathrm{m}^{2}$ of cesium. Waste composition had an effect on release from fresnoite glass ceramics with the normalized loss of strontium for FGC-9 and FGC-M4 being 9.7 and $6.8 \mathrm{~g} / \mathrm{m}^{2}$, respectively. The order of normalized cesium release is reversed for the two materials being 10.9 and $14.9 \mathrm{~g} / \mathrm{m}^{2}$, for $F G C-9$ and FGC-M4, respectively.

Comparison of Leaching in Silicate Water and Deionized Water

Three samples of each waste form were leached for 28 days at $90^{\circ} \mathrm{C}$ in silicate water containing silica and sodium bicarbonate with a pH of 7.5. These tests were performed to determine behavior of waste forms when in contact with silicate ground water. The results of these tests are presented in Tables 5 through 12. Figures 14, 15, and 16 compare the normalized release of molybdenum, strontium, and cesium after leaching for 28 days at $90^{\circ} \mathrm{C}$ in deionized water and silicate water.

The normalized molybdenum release from the materials after leaching in silicate water is compared to deionized water in Figure 14 . An increase in molybdenum loss is experienced from $B G C-4$ and $B G C-9$ after leaching in silicate 


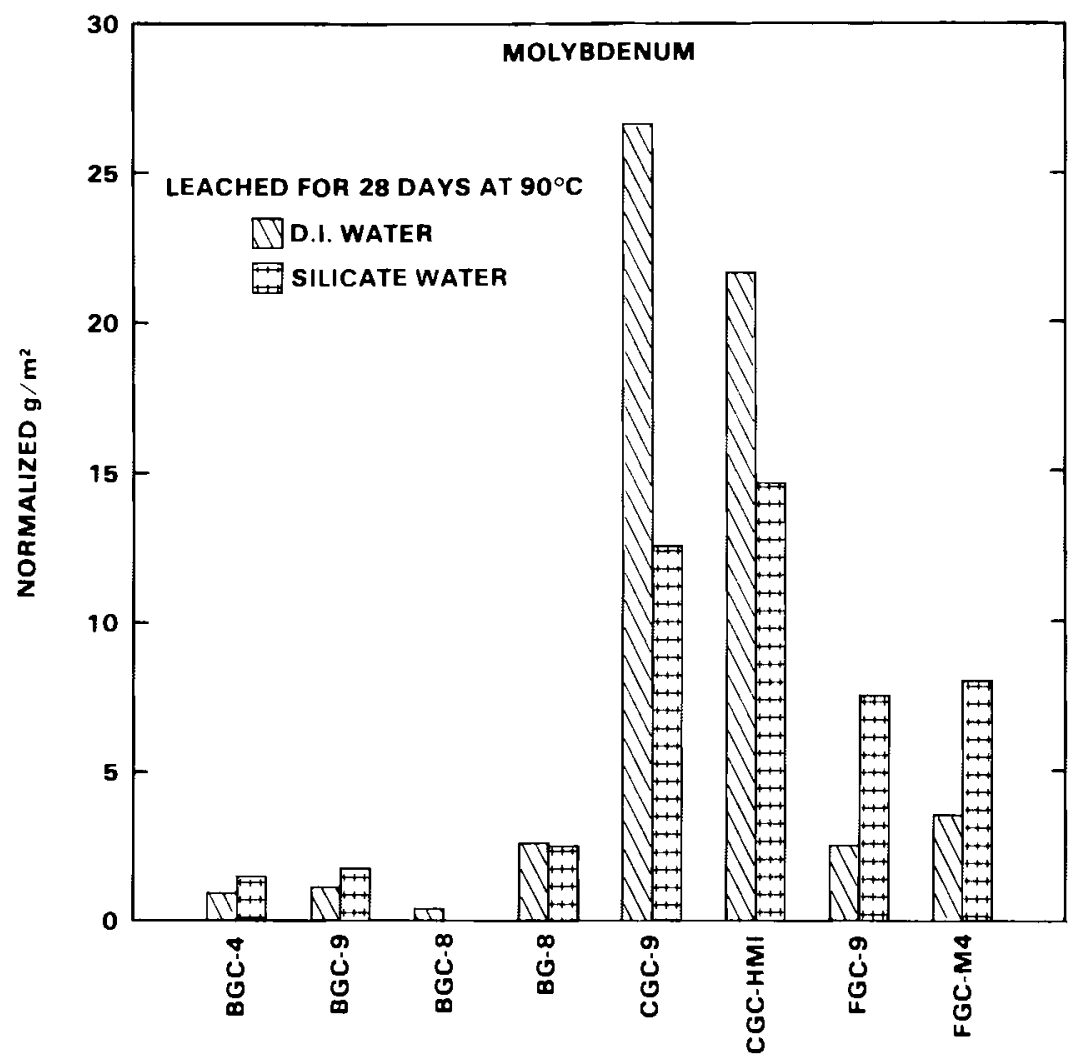

FIGURE 14. Comparison of Normalized Molybdenum Release After Leaching in Deionized and Silicate Water

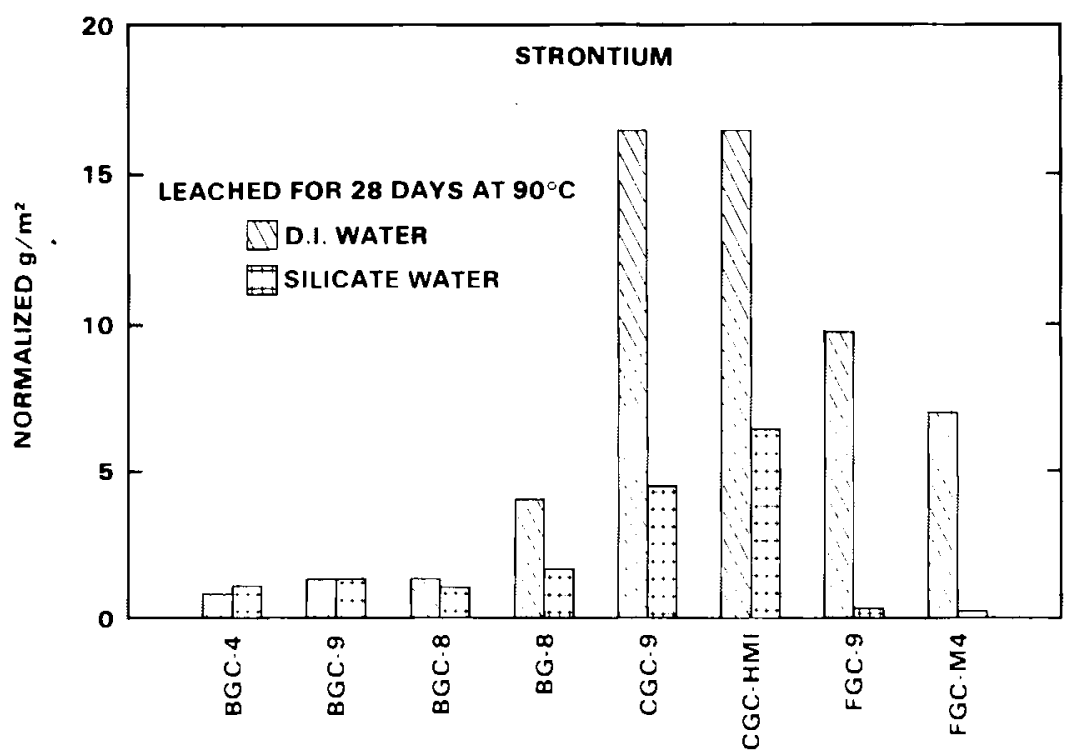

FIGURE 15. Comparison of Normalized Strontium Release After Leaching in Deionized and Silicate Water 


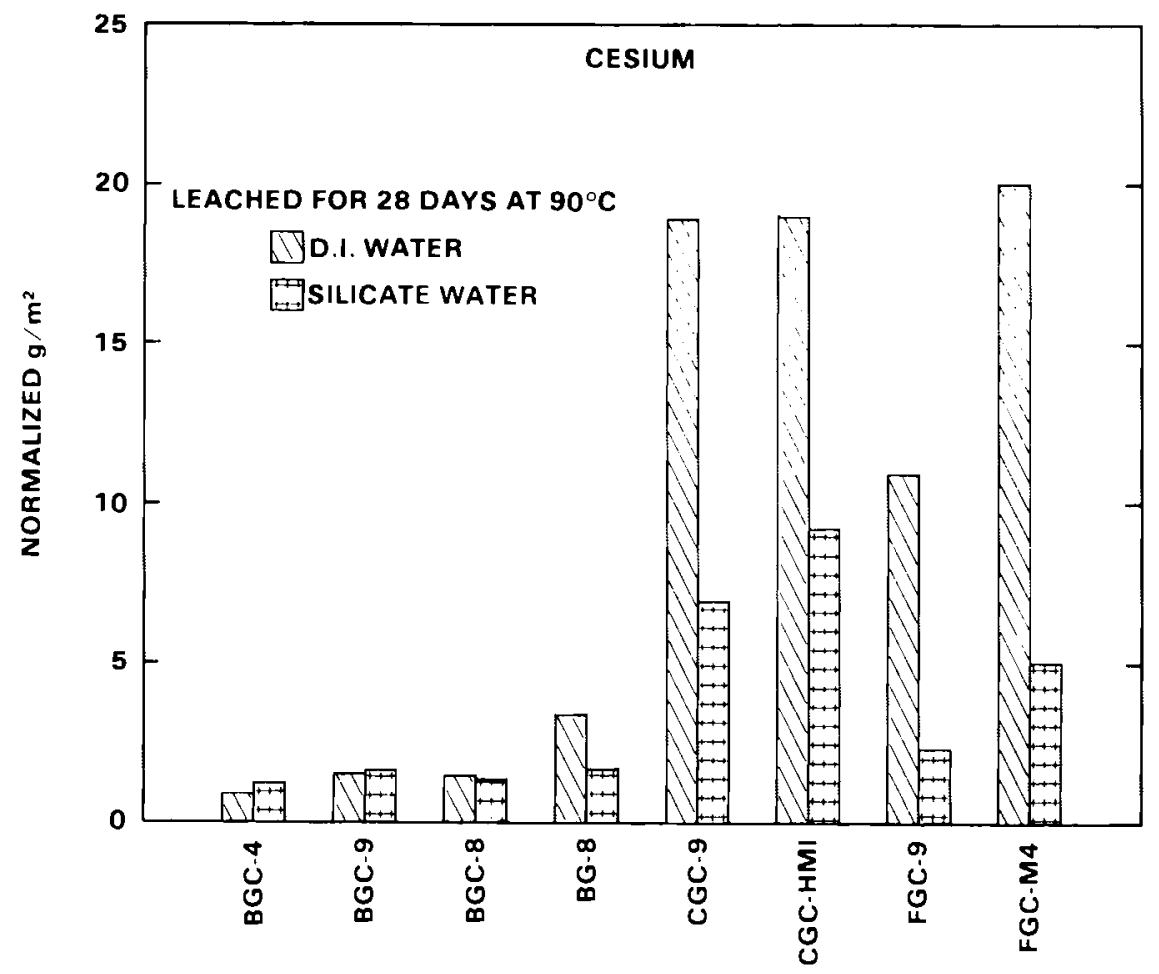

FIGURE 16. Comparison of Normalized Cesium Release After Leaching in Deionized and Silicate Water

water. No change was seen in $B G-8$. The release from $C G C-9$ and $C G C-H M I$ decreased with silicate water as the leachant, while the fresnoite glass ceramics experienced an increase in molybdenum release in silicate water.

Figure 15 shows normalized strontium loss after leaching in deionized and silicate water. The release from the basalt glass ceramics appears to be unaffected by the type of leachant. A two-fold improvement is realized by BG- 8 with normalized strontium loss of $4 \mathrm{~g} / \mathrm{m}^{2}$ in deionized water compared with $1.6 \mathrm{~g} / \mathrm{m}^{2}$ in silicate water. Decreases are also seen for celsian and fresnoite glass ceramics when leached in silicate water. CGC-9 released $6.9 \mathrm{~g} / \mathrm{m}^{2}$ of strontium in silicate water compared to 18.8 in deionized; CGC-HMI demonstrated releases of 9 and $19 \mathrm{~g} / \mathrm{m}^{2}$, respectively in silicate and deionized water. The magnitude of change was greatest for fresnoite glass ceramics as seen in the figure. The normalized strontium loss from $F G C-9$ decreased from $9.7 \mathrm{~g} / \mathrm{m}^{2}$ to $0.4 \mathrm{~g} / \mathrm{m}^{2}$ and from FGC-M4 the release decreased from $6.8 \mathrm{~g} / \mathrm{m}^{2}$ to $0.2 \mathrm{~g} / \mathrm{m}^{2}$ when the leachant was changed from deionized water to silicate water. 
Figure 16 compares cesium loss from the eight waste forms after leaching in deionized and silicate water. The normalized releases from $B G C-4, B G C-9$, and $B G C-8$ were the same in deionized and silicate water. The release from $B G-8$ in silicate water was nearly the same as the glass ceramics $\left(\sim 1.5 \mathrm{~g} / \mathrm{m}^{2}\right)$ and one half the value in deionized water. Large decreases in normalized cesium loss are evidenced for celsian and fresnoite glass ceramics leached in silicate water compared to deionized water. Losses decreased from 18.8 an $19.0 \mathrm{~g} / \mathrm{m}^{2}$ to 6.9 and $9.2 \mathrm{~g} / \mathrm{m}^{2}$ for CGC-9 and CGC-HMI, respectively after leaching in deionized water and silicate water. Fresnoite exhibited similar behavior with losses from FGC-9 decreasing from $10.8 \mathrm{~g} / \mathrm{m}^{2}$ to $2.3 \mathrm{~g} / \mathrm{m}^{2}$ and losses from FGC-M4 decreasing from $20.1 \mathrm{~g} / \mathrm{m}^{2}$ to $5.1 \mathrm{~g} / \mathrm{m}^{2}$ when silicate water was used as the leachant.

\section{Effect of Leach Container Material}

The bulk of the leach testing in this study was conducted in polypropylene bottles immersed in a glycerin bath operating at $90^{\circ} \mathrm{C}$. Since the time this study began the MCC static leach test procedure recommended Teflon ${ }^{\circledR}$ container placed in an oven. Additional concern surfaced due to the low pH values obtained with polypropylene containers. The question of container effect was addressed by leaching two glass ceramics in Teflon ${ }^{\circledR}$ containers and 76-68 borosilicate glass in polypropylene containers and comparing the results with previous data from this study.

The main concern expressed with leaching in polypropylene was the resulting leachate $\mathrm{pH}$, which, in most cases, becomes acid with leaching times greater than 7 days. Since dissolution mechanisms are pH dependant, the acidic conditions in much of the present work should be noted. The $\mathrm{pH}$ of leachates of three materials leached in polypropylene and Teflon ${ }^{\circledR}$ are shown in Figure 17 . The pH values of the leachates from Teflon ${ }^{\circledR}$ containers are higher than those of polypropylene containers after 7 days of leaching. The order of resultant leachate $\mathrm{pH}$ is the same for the three materials independant of container type with celsian glass ceramic causing the highest pH value, followed by 76-68 borosilicate 


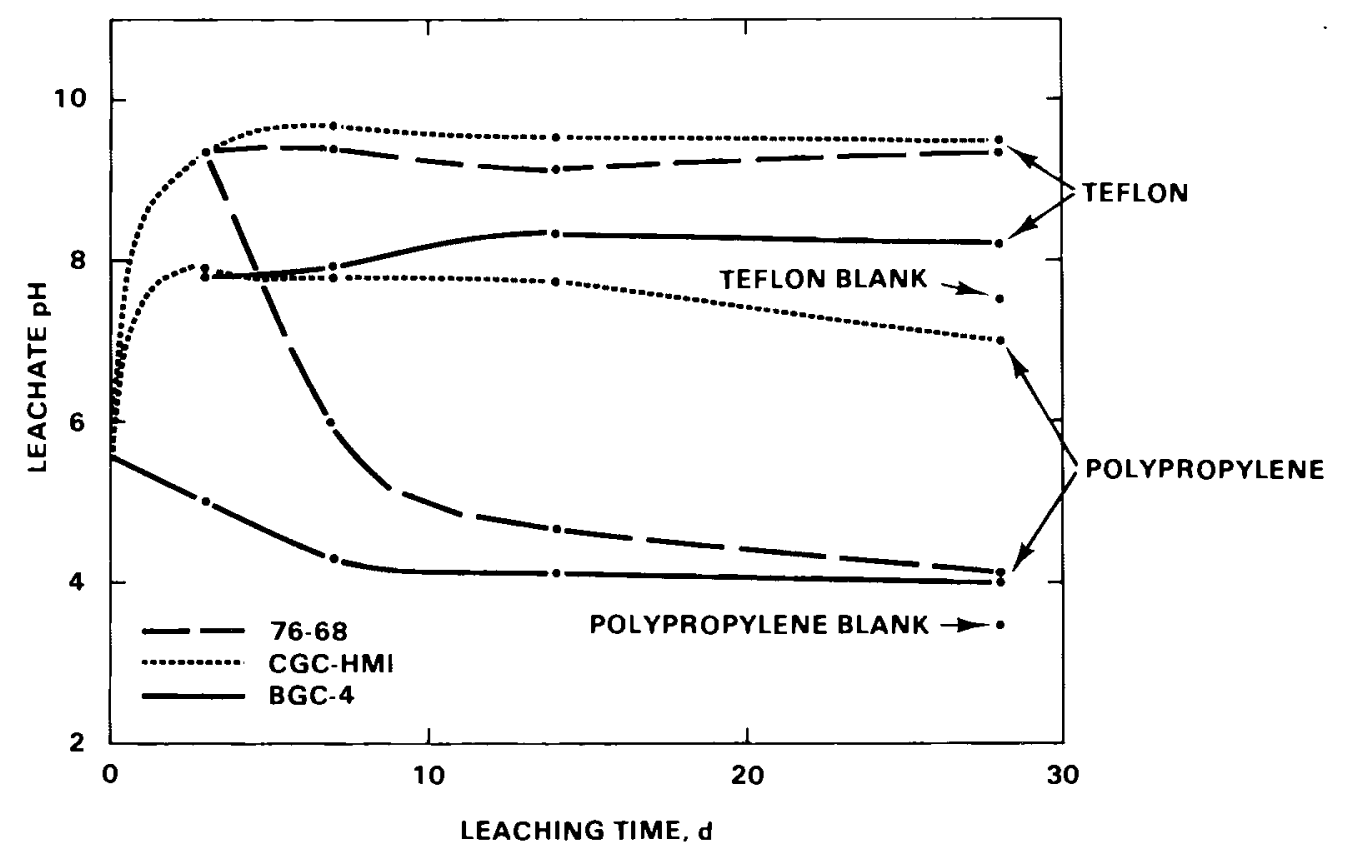

FIGURE 17. Leachate $\mathrm{pH}$ as a Function of Leaching Time for Three Materials Leached in Deionized Water at $90^{\circ} \mathrm{C}$ in Polypropylene and Teflon Containers

glass and basalt glass ceramic. The solution pH of the leach blanks, i.e., containers and deionized water alone, was lower than those with samples in both types of containers.

Despite the large difference in leachate $\mathrm{pH}$, the overall normalized elemental losses from the materials were not appreciably different. The normalized elemental losses from BGC-4 and CGC-HMI leached in Teflon ${ }^{\circledR}$ and 76-68 glass leached in polypropylene are shown in Tables B.1 through B.3 in Appendix B. In general, the releases from the samples leached in Teflon are slightly higher than those leached in polypropylene. Some notable exceptions to this are the losses of strontium from CGC-HMI and 76-68 glass as seen in Figure 18. The figure shows comparative data for the normalized release of silicon, strontium, cesium, and molybdenum from BGC-4, CGC-HMI, and 76-68 after leaching for 28 days at $90^{\circ} \mathrm{C}$ in deionized water using $\operatorname{Teflon}^{\circledR}$ and polypropylene containers. The largest differences are experienced by $\mathrm{BGC}-4$ in the release of silicon and 


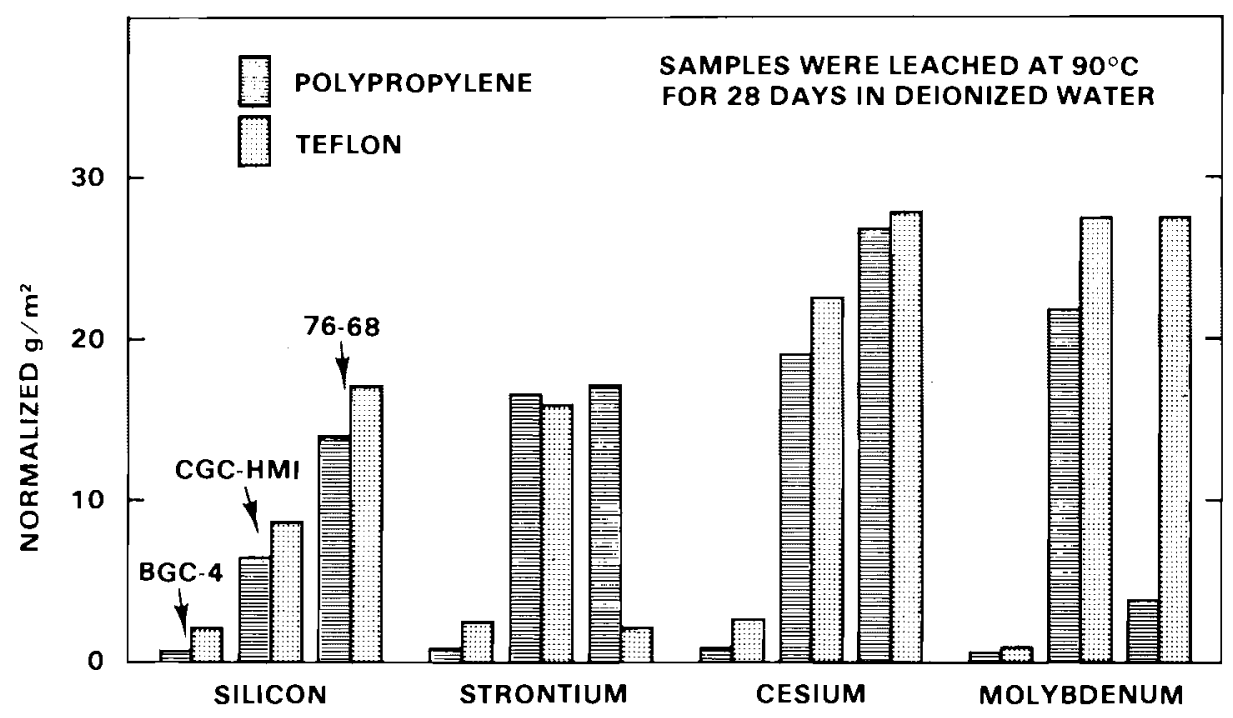

FIGURE 18. Comparison of Normalized Elemental Losses from Three Materials Leached for 28 Days at $90^{\circ} \mathrm{C}$ in Deionized Water in Polypropylene and Teflon Containers

cesium, increasing by factors of 2.5 to 3 , respectively. The total release of these elements, however, is still relatively small when compared with the releases from CGC-HMI and 76-68. The greatest change in strontium and molybdenum release is from 76-68 glass with strontium release being a factor of 8.5 less when leached in Teflon ${ }^{\circledR}$. Conversely, the molybdenum release was a factor of 7 greater.

As noted in the preceding discussion the overall amount of species leached from the glass ceramic waste forms does not differ greatly when leached in Teflon ${ }^{\circledR}$ or polypropylene in deionized water. While large differences are seen in the leachate $\mathrm{pH}$ values between the two container types, it should be noted that ultimate disposal of waste forms will not be in polypropylene or Tef $10{ }^{\circledR}$ and in the event water contacts the waste from it will not be deionized water with a pH value of 5.5. The glass ceramic materials leached in silicate water resulted in leachate $\mathrm{pH}$ values of $\sim 7.7$, independant of material type. These results illustrate the buffering action of the simulated ground water which counteracts the container effect. Since different leaching mechanisms 
dominate at low pH values, the results of this study may prove helpful in extrapolating the behavior of waste forms in the presence of air and water when in a radiation field which has been shown to produce nitric acid (McVay and Pederson 1981).

Surface Characterization

Selected samples were examined with scanning electron microscopy (SEM) and energy dispersive x-ray analysis (EDAX) with major emphas is on surface characteristics following leaching. Four waste forms were examined in the as-prepared condition and following leaching at $90^{\circ} \mathrm{C}$ for 28 days in deionized water. Basalt glass ceramic containing PW-8a-2 calcine leached in silicate water was also examined.

Figure 19 shows SEM micrographs of BG-8 samples before and after leaching. The as-prepared surface is characterized by plateaus and valleys typical of diamond-sawed surfaces of brittle materials (photo A). After leaching, the ridges of the plateaus have been rounded and small white needle-like features are seen (photo B). These were identifed using EDAX as an aluminum-rich phase, probably an aluminum hydroxide, resembling the weathering products of rocks, and an intermediate compound in the formation of clays. Photo $C$ shows the center area of $B$ at a higher magnification. The surface revealed in this photo is sponge-like in texture with dendritic crystals seen in the lower left. These crystals are identified as spinel that formed during fabrication.

Figure 20 illustrates the effect of recrystallization of basalt glass on surface characteristics after leaching. This figure includes micrographs of $B G C-8$ before and after leaching in deionized and silicate water for 28 days at $90^{\circ} \mathrm{C}$. Comparing photo $A$ (before) with B and C (leached in deionized and silicate water, respectively) no significant difference in morphology is seen. The ridges of the plateaus are not rounded as evidenced in BG-8. Examination of these areas at higher magnification (photos $D, E$, and $F$ ) reveals small crystals on the surface of the sample leached in deionized water, although not present in the sample leached in silicate water. These particles, seen in greater detail in photo $G$, are rich in aluminum, with a composition apparently the same as the needles seen in BG-8 (Figure 22), probably aluminum hydroxide. 


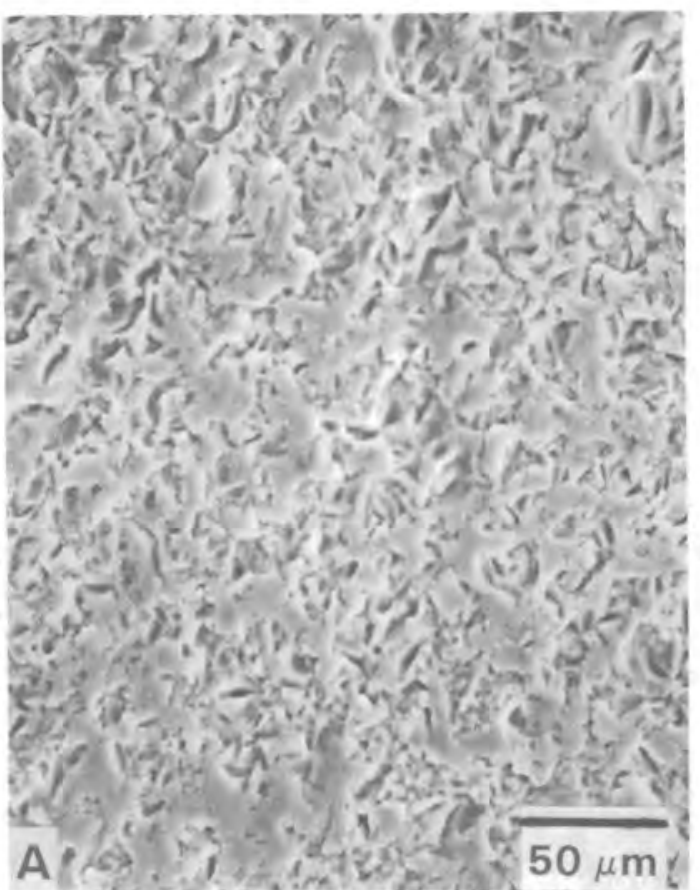

BEFORE LEACHING

BG-8

SAMPLES WERE LEACHED

AT $90^{\circ} \mathrm{C}$ FOR 28 DAYS IN

DEIONIZED WATER

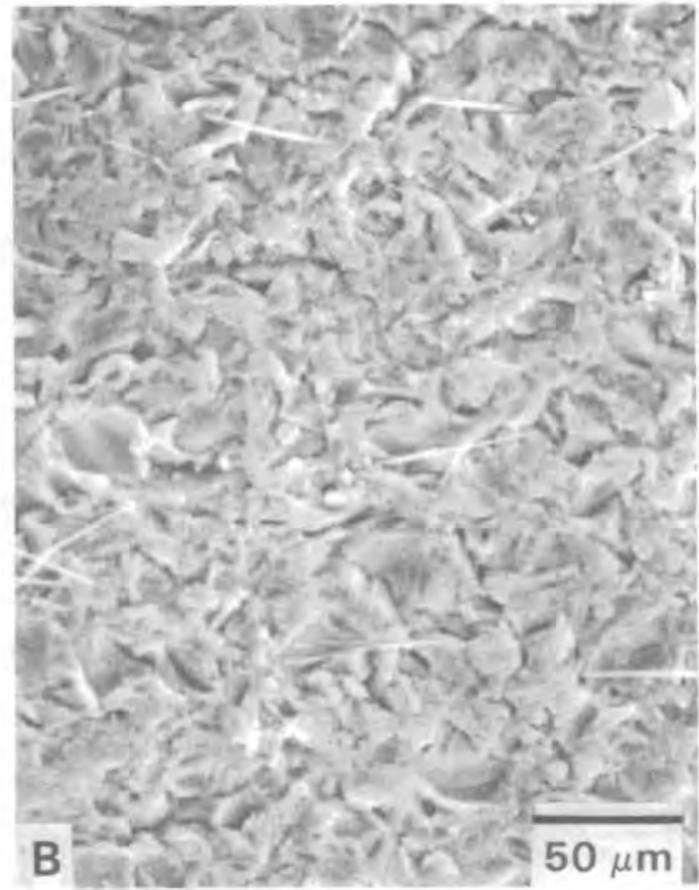

AFTER LEACHING

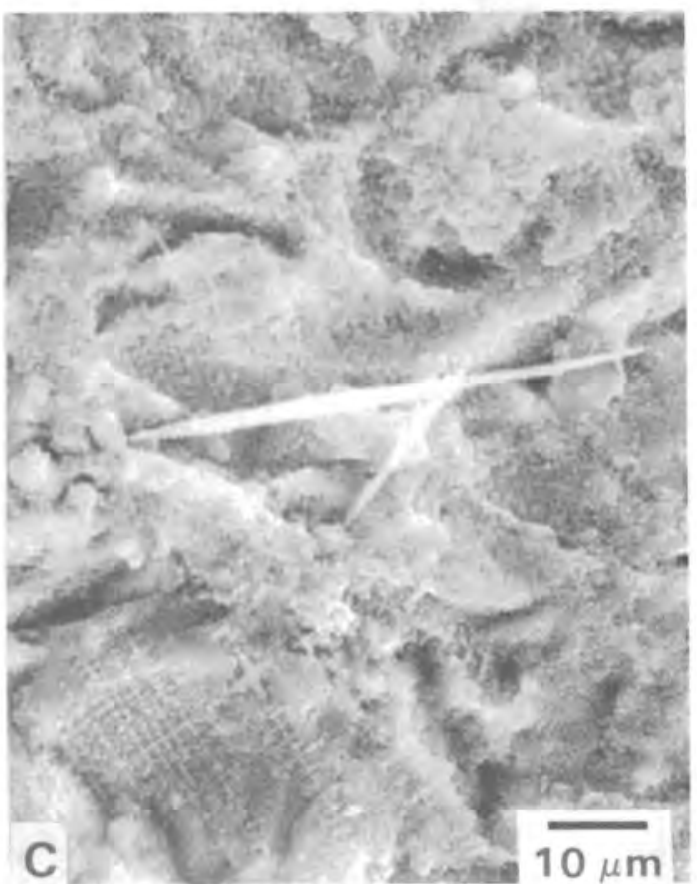

FIGURE 19. SEM Micrographs of BG-8 Surfaces Before and After Leaching in Deionized Water at $90^{\circ} \mathrm{C}$ for 28 Days 
BEFORE LEACHING
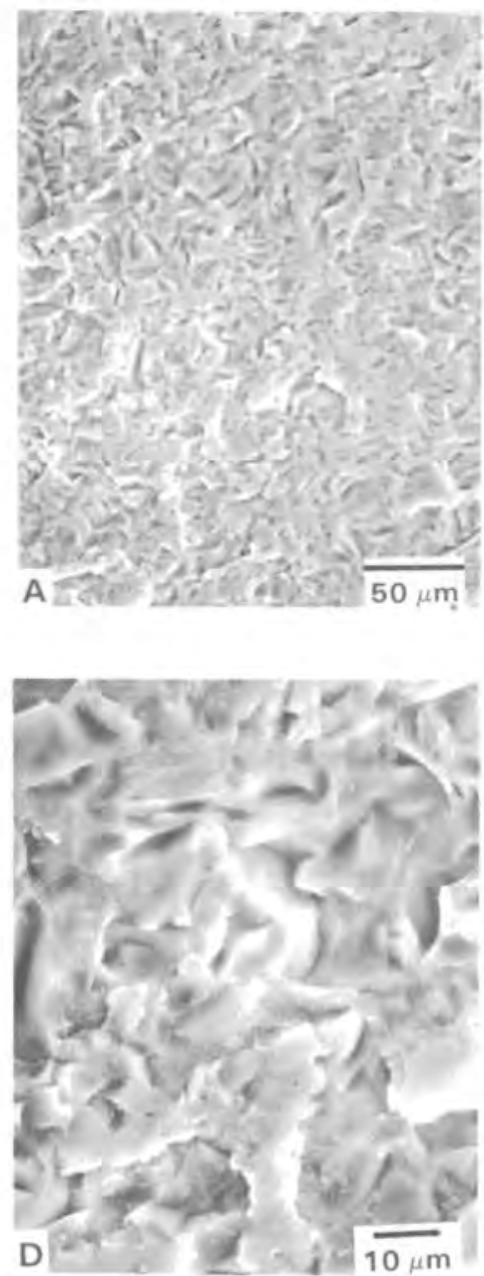

BGC-8

SAMPLES WERE LEACHED AT $90^{\circ} \mathrm{C}$ FOR 28 DAYS
AFTER LEACHING DEIONIZED WATER
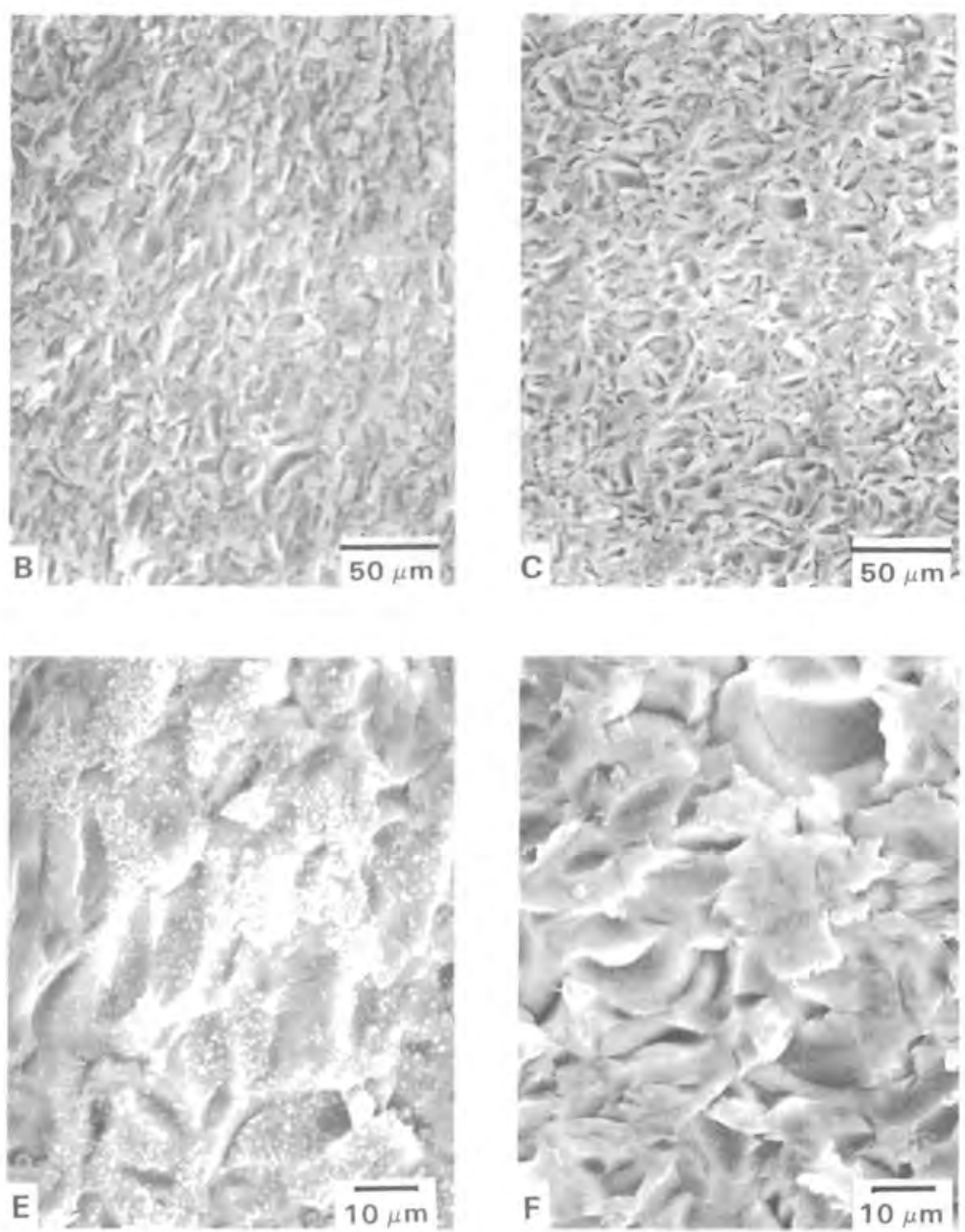

AFTER LEACHING SILICATE WATER
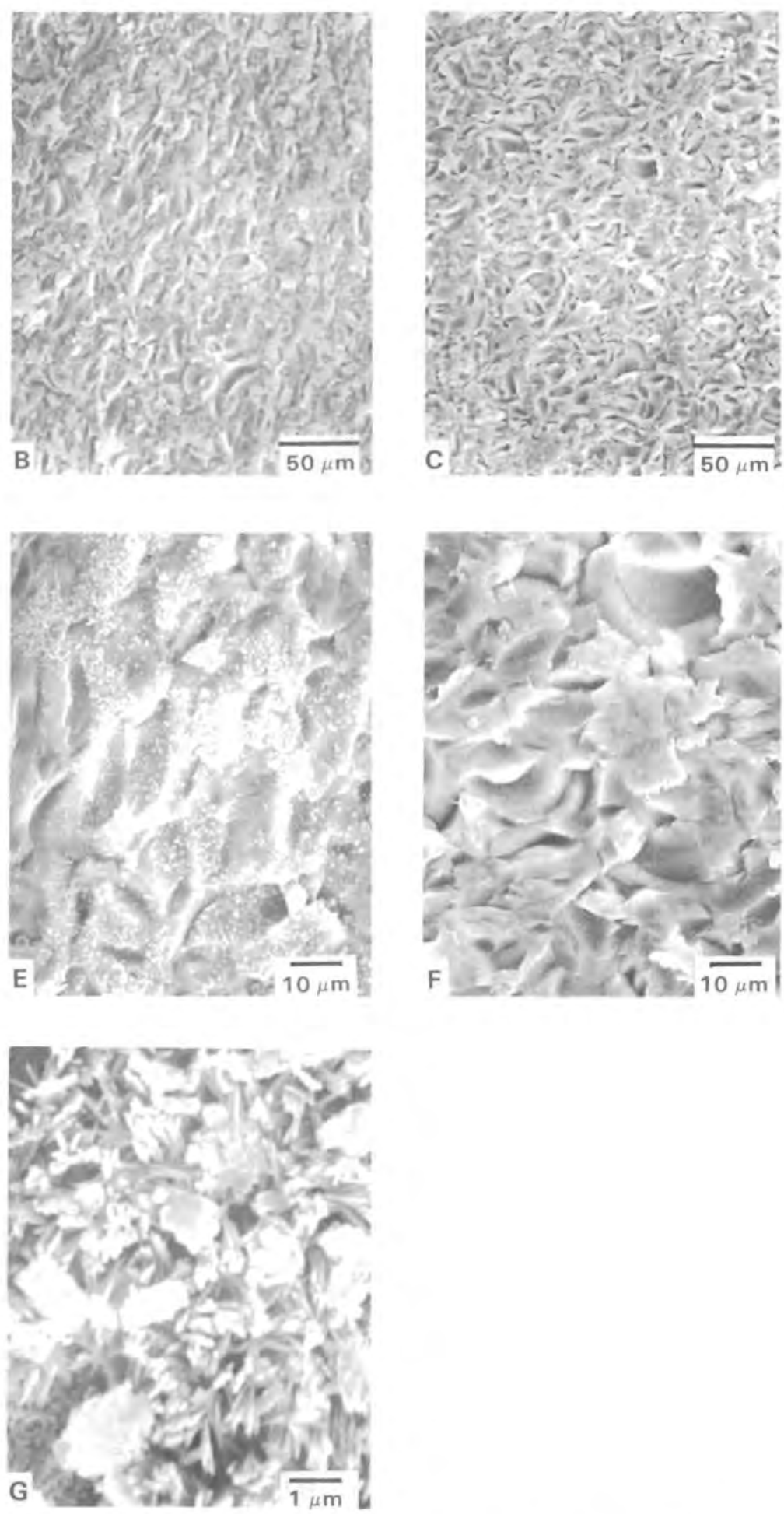

FIGURE 20. SEM Micrographs of BGC-8 Surfaces Before and After Leaching in Deionized and Silicate Water at $90^{\circ} \mathrm{C}$ for 28 Days 
Figure 21 shows SEM micrographs of CGC-HMI before and after leaching. Before leaching, the surface is characterized by the traditional cutting texture and noticeable crystal orientations (photo A). Photo B illustrates the effects of leaching on surface morphology revealing a random orientation of needle-like crystals around larger particles. It appears that during leaching the glassy phase was selectively dissolved, leaving a network of crystals. Photo $C$ shows enlarged detail of the unleached surface revealing small bright areas within what appears to be a glassy phase. After leaching the smooth features are not present; however, bright particles are seen on the surface (photo D). EDAX shows these particles to be enriched in aluminum, silicon, calcium, and zinc. These particles are believed to be present in the sample before leaching, unlike the aluminum-rich phases formed during the leaching of $\mathrm{BG}-8$ and $\mathrm{BGC}-8$.

Figure 22 illustrates the effect of leaching on fresnoite glass ceramics. Photo $A$ shows the general surface morphology of the as-prepared sample. After leaching for 28 days in deionized water the surface is characterized by a structure similar to CGC-HMI, containing rod-shaped crystals (photo B). The surface also contains a large number of small bright particles, detailed in photo $C$. These particles are predominantly lead which precipitated during leaching. 


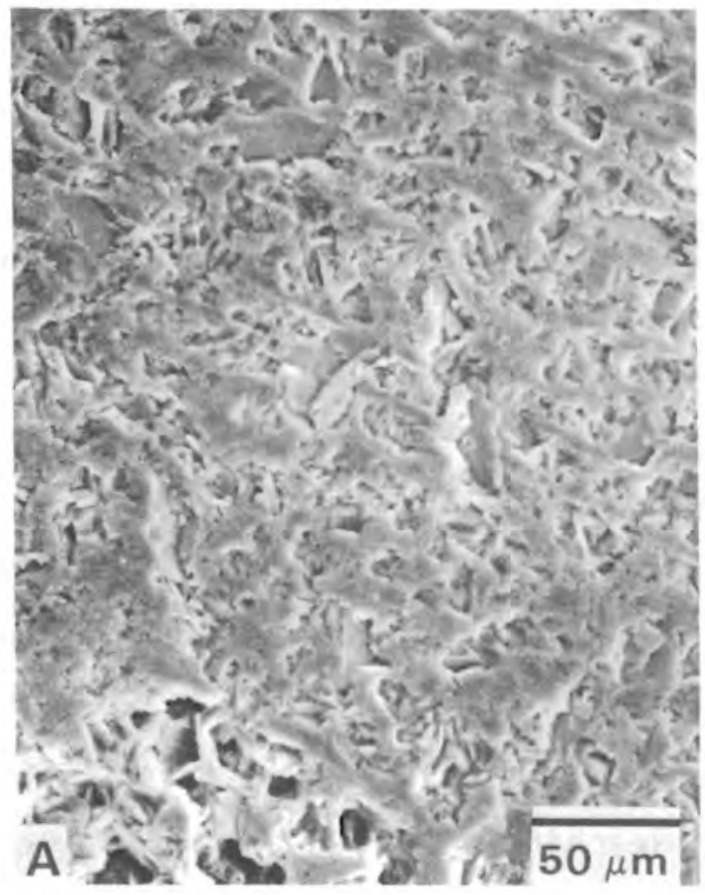

BEFORE LEACHING

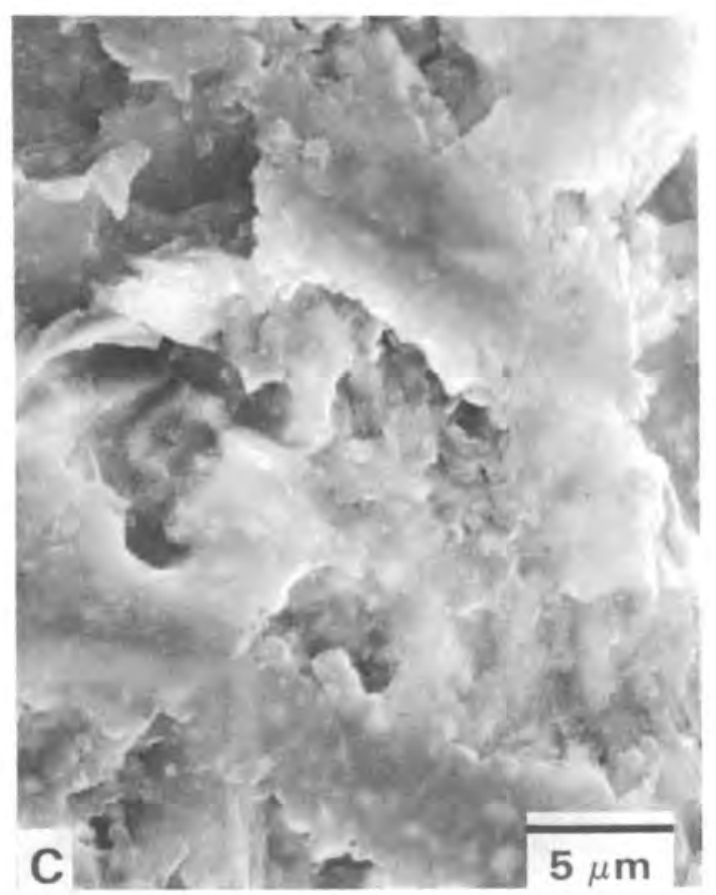

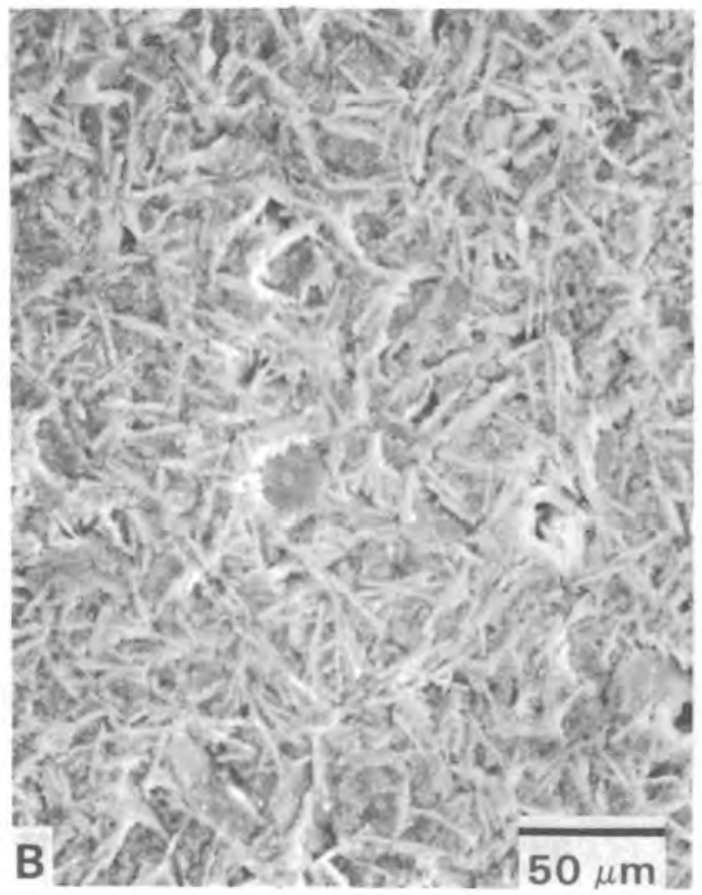

AFTER LEACHING

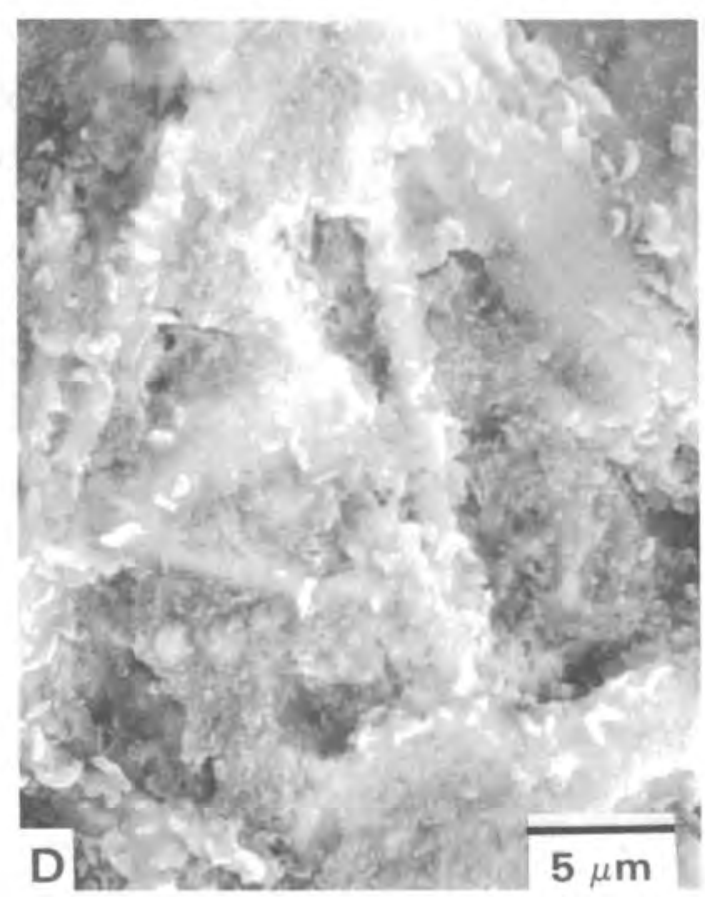

\section{CGC-HMI}

SAMPLES WERE LEACHED AT $90^{\circ} \mathrm{C}$ FOR 28 DAYS IN DEIONIZED WATER

FIGURE 21. SEM Micrographs of CGC-HMI Surfaces Before and After Leaching in Deionized Water at $90^{\circ} \mathrm{C}$ for 28 Days 


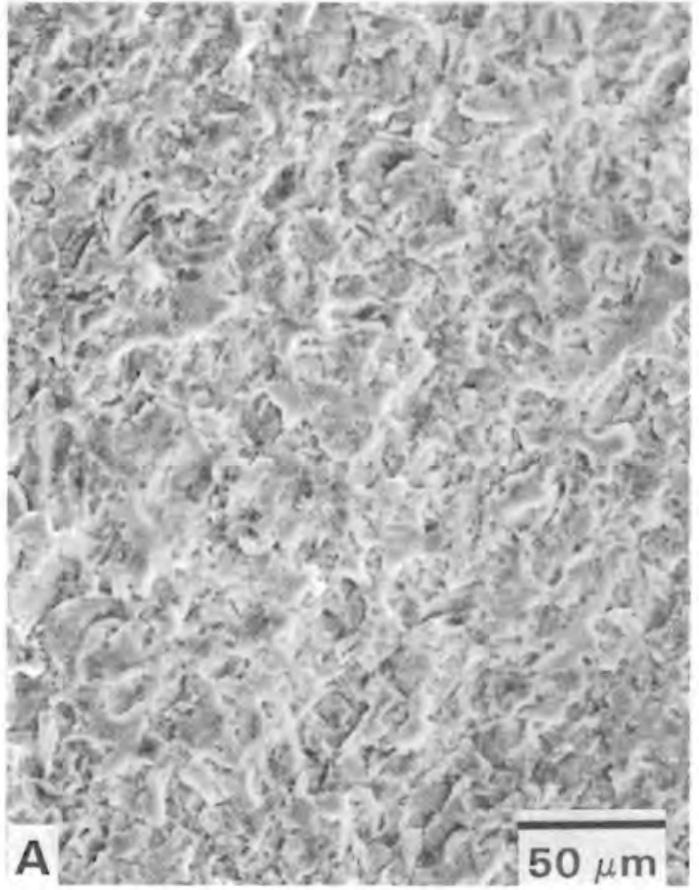

BEFORE LEACHING

FGC-M4

SAMPLES WERE LEACHED

AT $90^{\circ} \mathrm{C}$ FOR 28 DAYS IN

DEIONIZED WATER

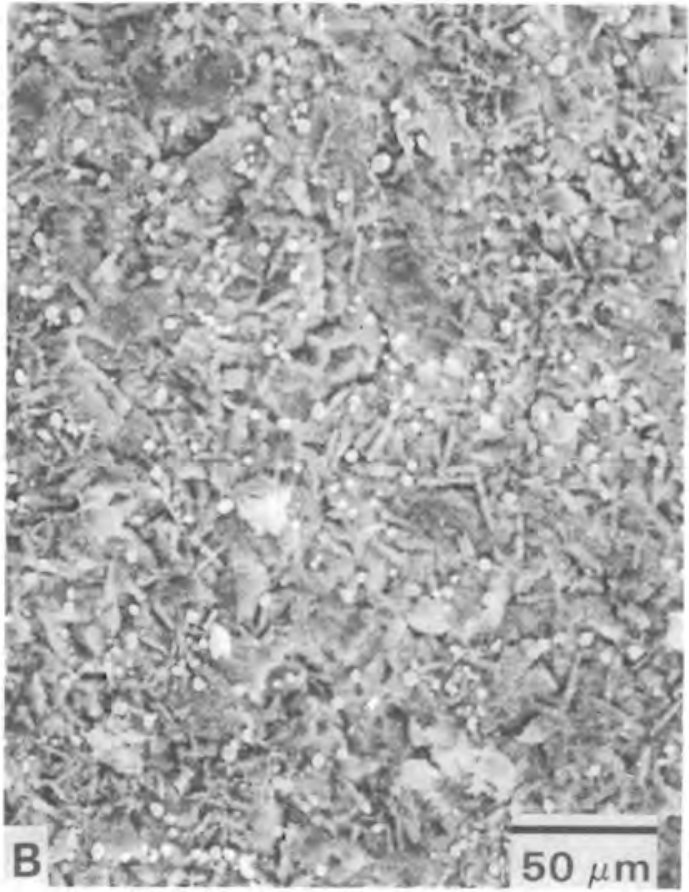

AFTER LEACHING

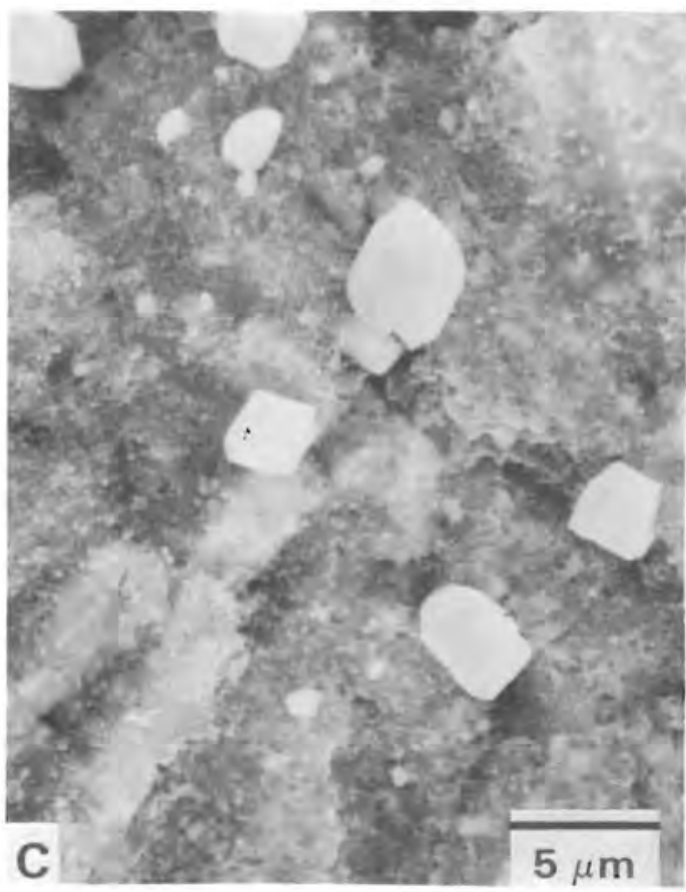

FIGURE 22. SEM Micrographs of FGC-M4 Surfaces Before and After Leaching in Deionized Water at $90^{\circ} \mathrm{C}$ for 28 Days 


\section{CONCLUSIONS}

One vitreous and seven glass ceramic waste forms were prepared and subjected to static leach tests. The glass ceramic materiais included basalt, celsian, and fresnoite, each containing $20 \mathrm{wt} \%$ simulated high-leve1 waste calcine. The basalt-based glass ceramics were prepared with either PW-9, PW-8a-2, or PW-4b-7 calcine. The celsian and fresnoite products contained either PW-9 calcine or a composition similar to the calcines used in their development at Hahn Meitner Institute. The leaching conditions employed in the tests were similar to those outlined in the Materials Characterization Center's static leach test procedure (MCC-1).

A summary of selected results is shown in Figure 23 with a comparison of normalized elemental losses of silicon, molybdenum, cesium, and strontium from four of the waste forms from this study compared to the 10sses from 76-68 reference borosilicate waste glass. These materials were leached for 28 days at $90^{\circ} \mathrm{C}$ in deionized water using polypropylene containers. As seen in the figure, the releases from basalt glass ceramic $(B G C-8)$ are quite low with the largest

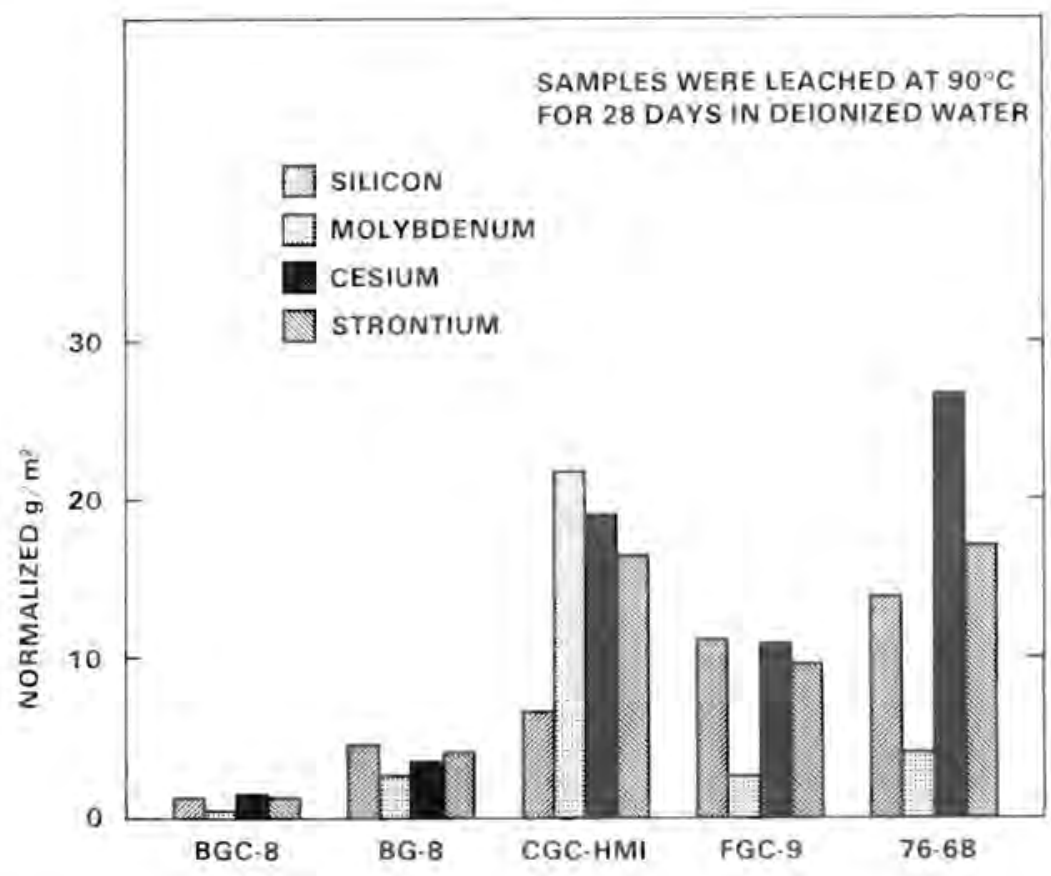

FIGURE 23. Comparison of Normalized Elemental Releases from 76-68 Waste Glass with Those from Four Materials from This Study 
. 
release $\sim 1.5 \mathrm{~g} / \mathrm{m}^{2}$. Crystallization had a positive effect on leachability (about four fold) as seen by comparison of BGC- 8 with basalt glass (BG-8). The release of molybdenum from celsian glass ceramic (CGC-HMI) was $\leadsto 9$ times larger than from either BG-8 or fresnoite glass ceramic (FGC-9). Cesium and strontium losses from CGC-HMI are also appreciably larger than those from BGC-8 and FGC-9. The last comparison seen in the figure is the releases from 76-68 borosilicate waste glass and four materials from this study. Under the stated conditions, the basalt-based materials and fresnoite glass ceramic proved superior to 76-68 waste glass in the release of all species. Celsian glass ceramic demonstrated lower silicon and cesium losses, but had much higher molybdenum releases than 76-68. Strontium releases were nearly equal from celsian and 76-68 waste glass. The results of the leach tests allow the following conclusions to be drawn:

- Basalt glass ceramics containing simulated high-level waste calcines demonstrated the lowest normalized losses of the glass ceramics investigated.

- Waste-stream compositional variation had an insignificant effect on the overall durability of any of the glass ceramic waste forms studied.

- Crystallization of basalt-based products improved leach resistance by factors of 2 to 10 over their vitreous counterparts.

- The leachability of basalt glass ceramics in silicate water was nearly the same as in deionized water.

- The leachability of celsian and fresnoite glass ceramics in silicate water was lower than in deionized water, except for the release of molybdenum from fresnoite glass ceramics which increased slightly.

- Polypropylene containers caused leachates to become acidic with time, even with leaching of alkali from the waste forms.

- The normalized elemental losses from samples leached in Teflon ${ }^{\circledR}$ containers were generally slightly larger than those leached in polypropylene. 
- The basalt-based waste forms and fresnoite glass ceramics demonstrated lower overall normalized elemental losses than 76-68 reference borosilicate high-level waste glass. 


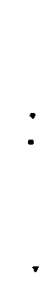




\section{REFERENCES}

Bea11, G. H. and H. L. Rittler. 1976. "Basalt Glass Ceramics," Bull. Am Ceram. Soc. 55(6):579.

De, A. K. et al. 1976. "Development of Glass Ceramics for the Incorporation of Fission Products," Bu11. Am. Ceram. Soc. 55(5):500.

De, A. K., B. Lucksheiter, G. Malow and E. Schiewer. 1977. Fission Products in Glasses Part II: Development of Glass Ceramics, HMI-B218, Hahn Meitner Institute, Berlin, West Germany.

Deju, R. A. and G. C. Evans. 1980. "Status Report on Studies to Assess the Feasibility of Storing Nuclear Waste in Columbia Plateau Basalts." In Proceeding of Scient if ic Basis for Nuclear Waste Management, Vol. 2. C. J. Northrup (ed), Plenum Press, New York, New York.

Gray, W. J. 1980. "Volatility of Some Potential High-Level Radioactive Waste Forms," Radioactive Waste Management, pp. 147-170, Volume 1(2), Harwood Academic Publishers, New York, New York.

Guber, W. et a1. 1979. "Development and Characterization of the Glass Ceramic VCP-15 for Immobilization of High-Level Liquid Radioactive Waste," In Proceedings of Ceramics in Nuclear Waste Management, pp. 188-192, DOE CONF-790420, Technical Information Center, 0ak Ridge, Tennessee.

Lokken, R. 0. and J. M. Rusin. 1980. "Evaluation of Basalt-Based Waste Forms," Bull. Am. Ceram. Soc. 59:392

Lutze, W., J. Borardt and A. K. De. 1979. "Characterization of Glass and Glass-Ceramic Nuclear Waste Forms." Proceedings of Scient ific Basis for Nuclear Waste Management, Vol. 1. G. J. McCarthy (ed), Plenum Press, New York, New York.

McMillan, P. W. 1979. Glass Ceramics, 2nd Ed. Academic Press, New York, New York.

McVay, G. L. and L. R. Pederson. 1981. "Effect of Gamma Radiation on Glass Leaching." J. Am. Ceram. Soc., 64:3, pp 154-158.

Oguino, N. et al. 1979. "Solidification of HLLW by Glass-Ceramic Process." In Proceedings of Ceramics in Nuclear Waste Management, pp. 143-149, DOE CONF-790420, Technical Information Center, Oak Ridge, Tennessee

Rusin, J. M. 1981. An Assessment of Glass Ceramic Waste Forms, PNL-3515, Pac if ic Northwest Laboratory, Richland, Washington.

Wald, J. W. and J. H. Westsik, Jr. 1979. "Devitrification and Leaching Effects in HLW-Glass--Comparison of Simulated and Fully Radioactive Waste Glass," In Proceedings of Ceramics in Nuclear Waste Management, pp. 277-283, DOE CONF-790420, Technical Information Center, Oak Ridge, Tennessee. 
APPENDIX A

$\underline{X \text {-RAY DIFFRACTION TRACES }}$ 


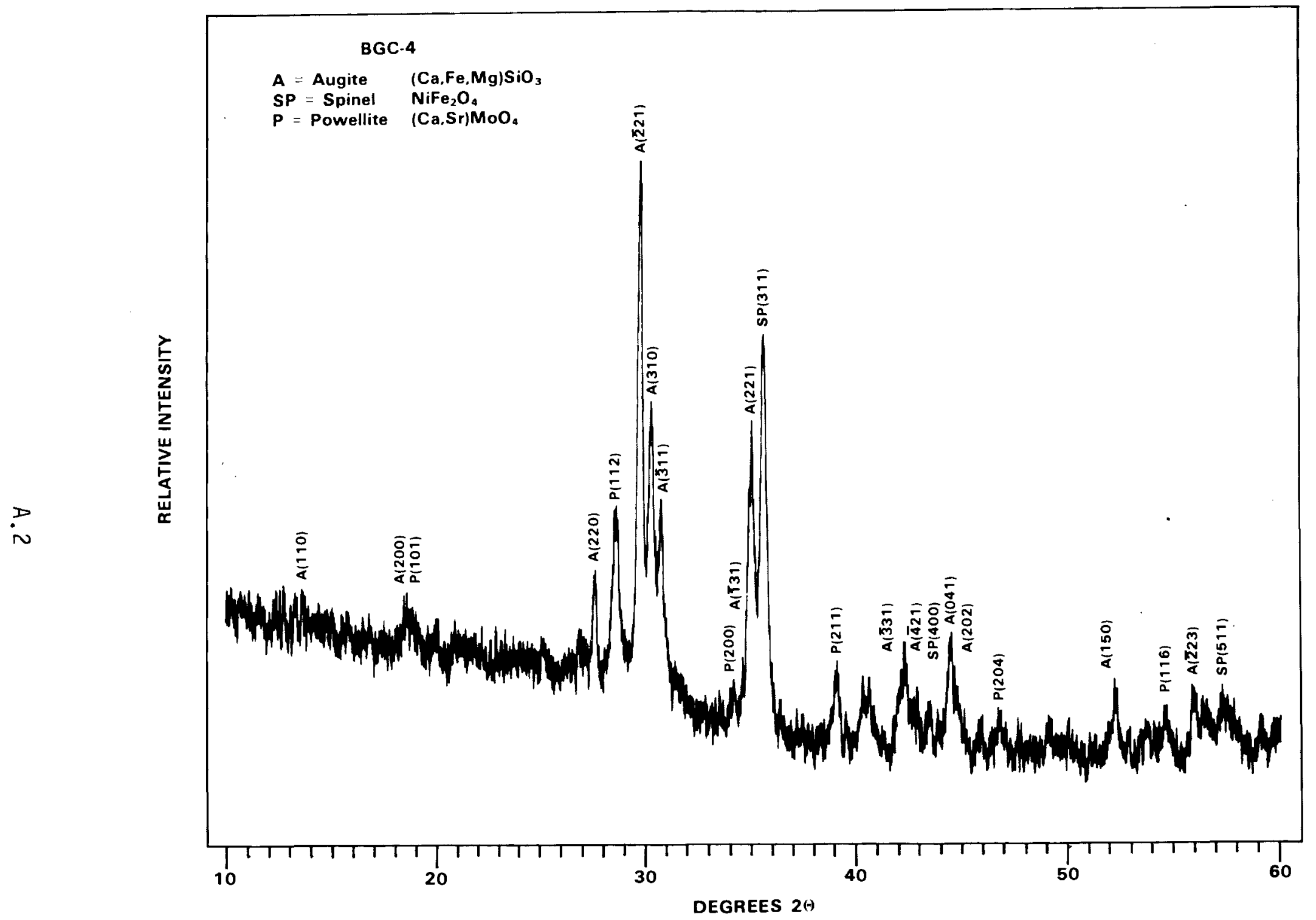

FIGURE A.2. X-Ray Diffraction Pattern of Basalt Glass Ceramic Containing 20 wt\% PW-4b-7 Calcine 


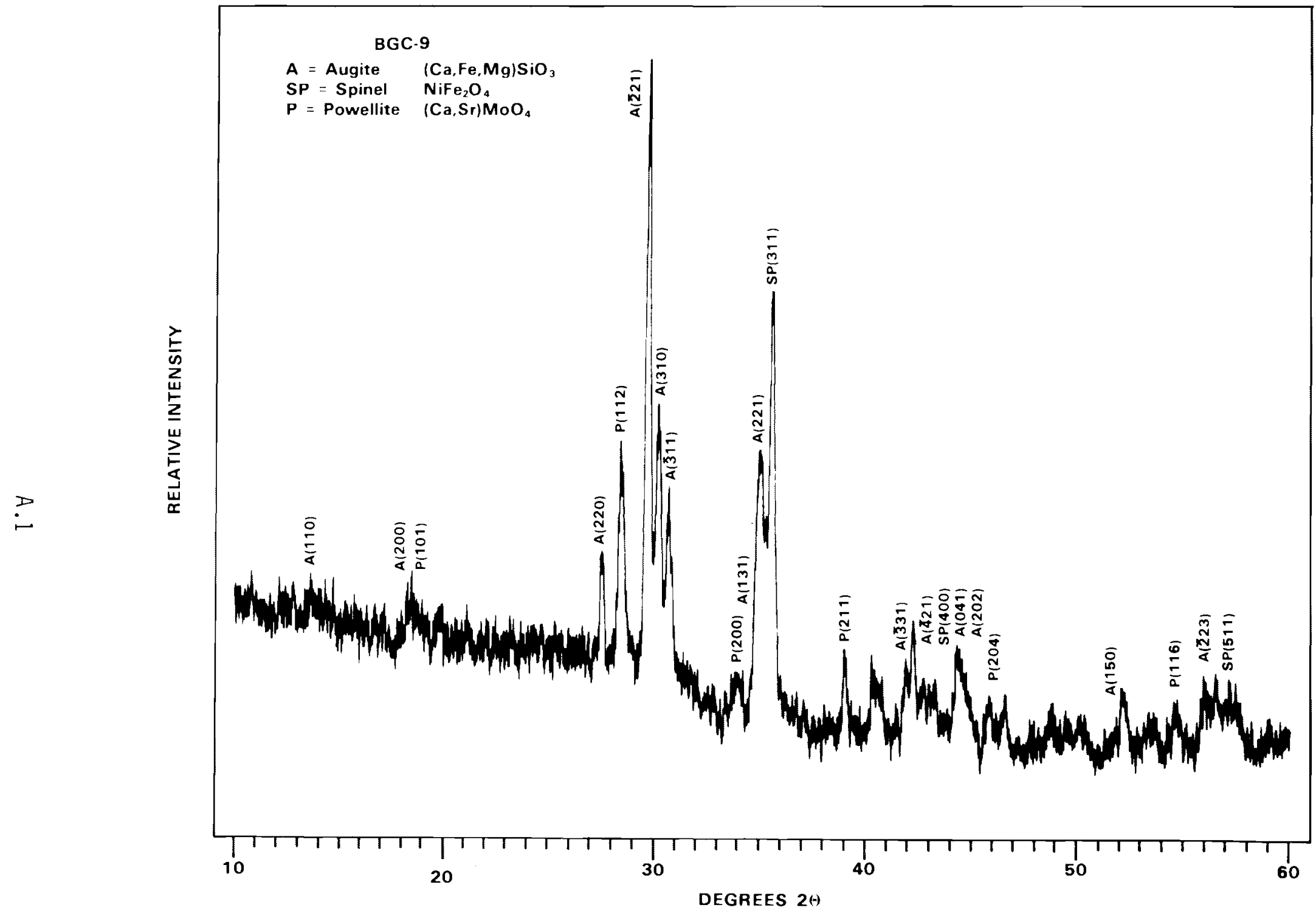

FIGURE A.1. X-Ray Diffraction Pattern of Basalt Glass Ceramic Containing 20 wt\% PW-9 Calcine 


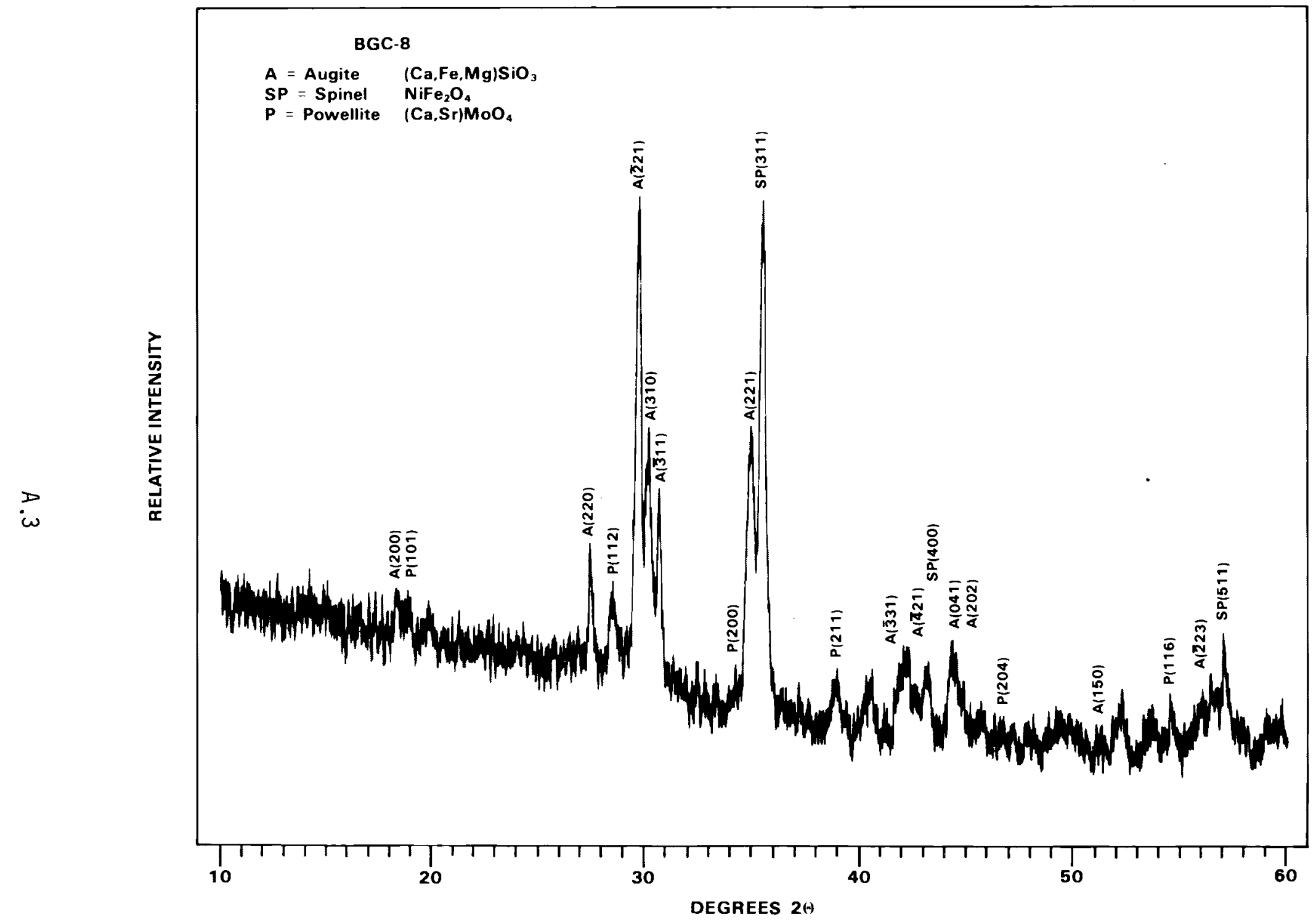

FIGURE A.3. X-Ray Diffraction Pattern of Basalt Glass Ceramic Containing 20 wt\% PW-8a-2 Calcine 


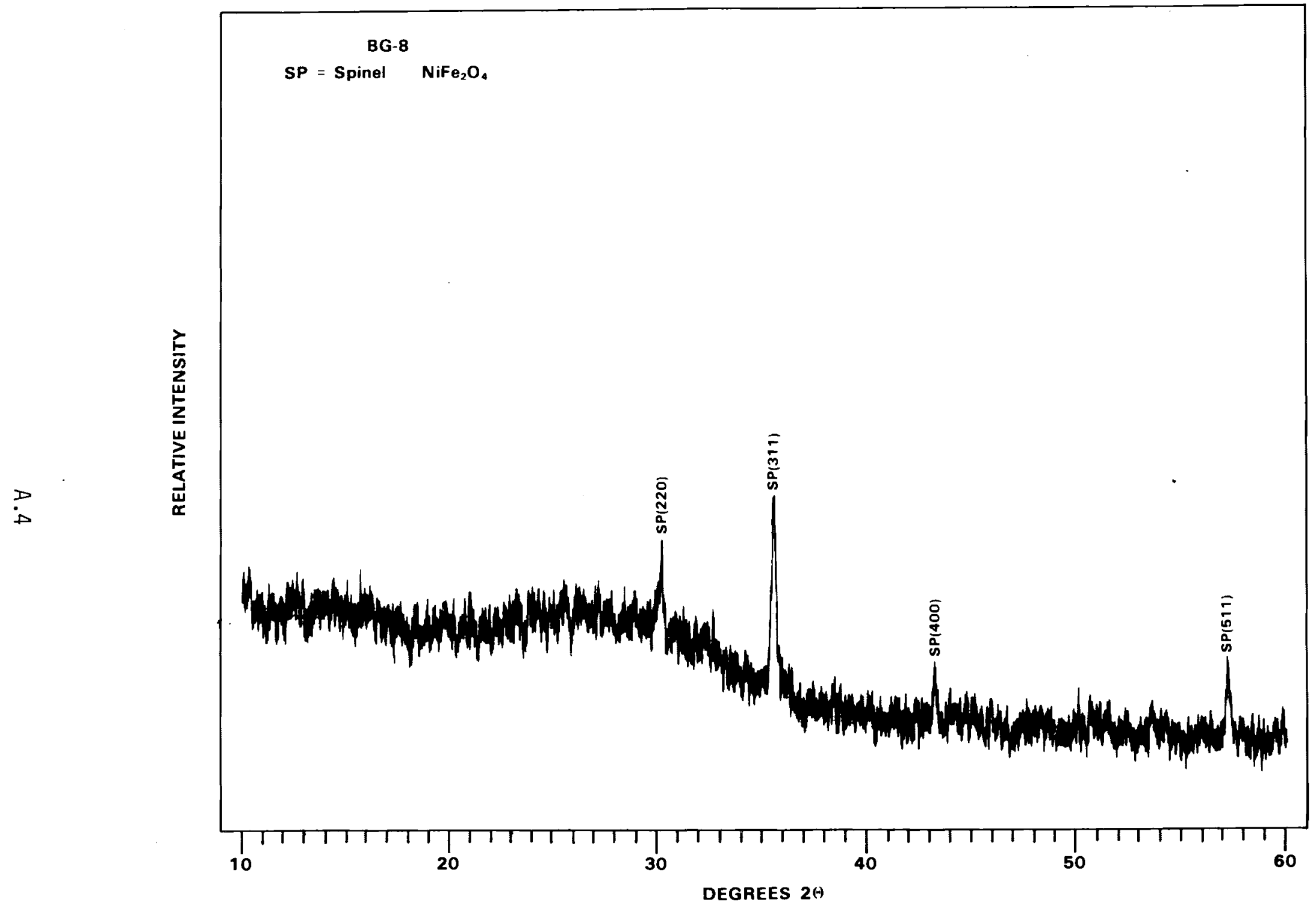

FIGURE A.4. X-Ray Diffraction Pattern of Basalt Glass Containing 20 wt\% PW-8a-2 Calcine 


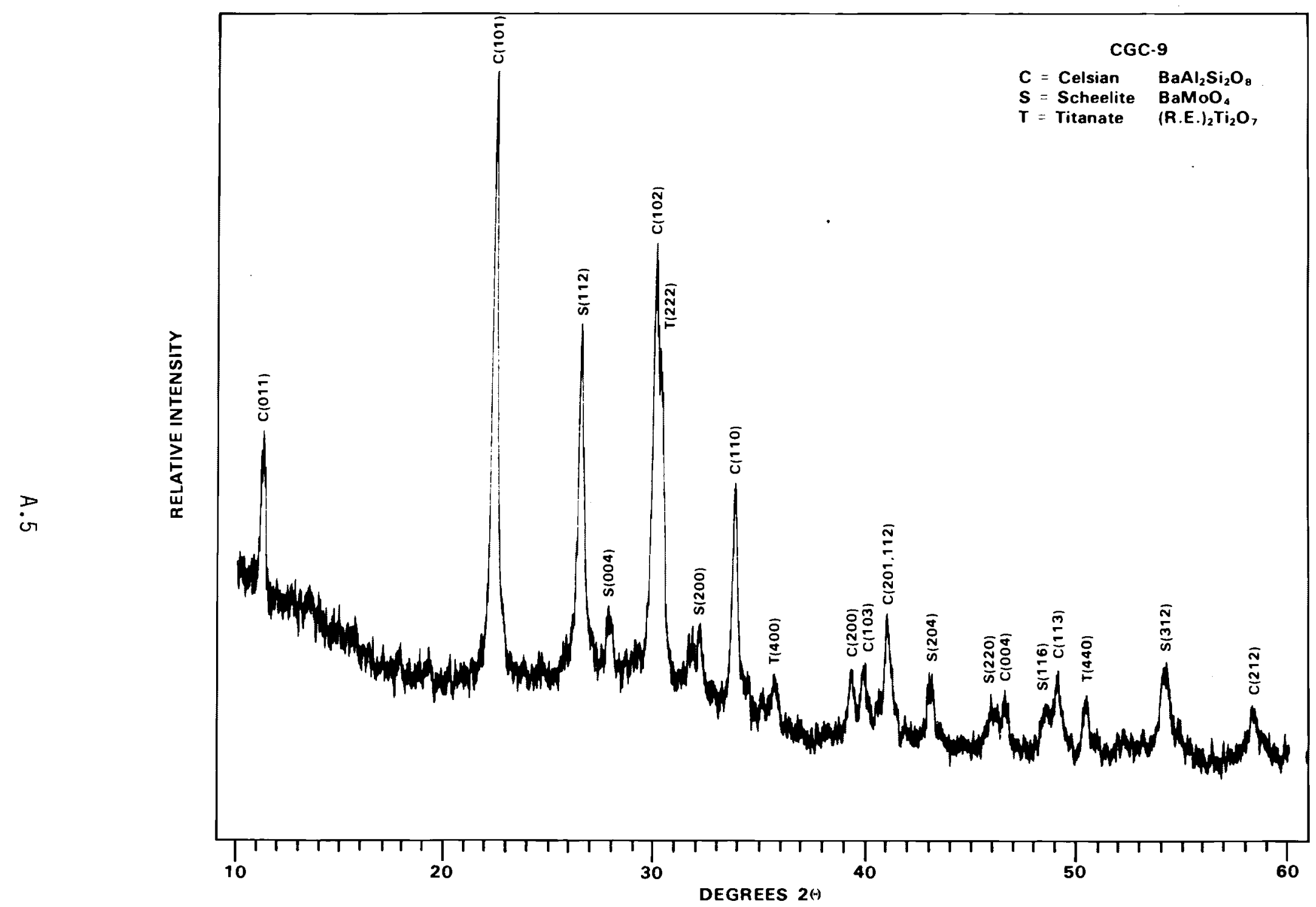

FIGURE A.5. X-Ray Diffraction Pattern of Celsian Glass Ceramic Containing 20 wt\% PW-9 Calcine 


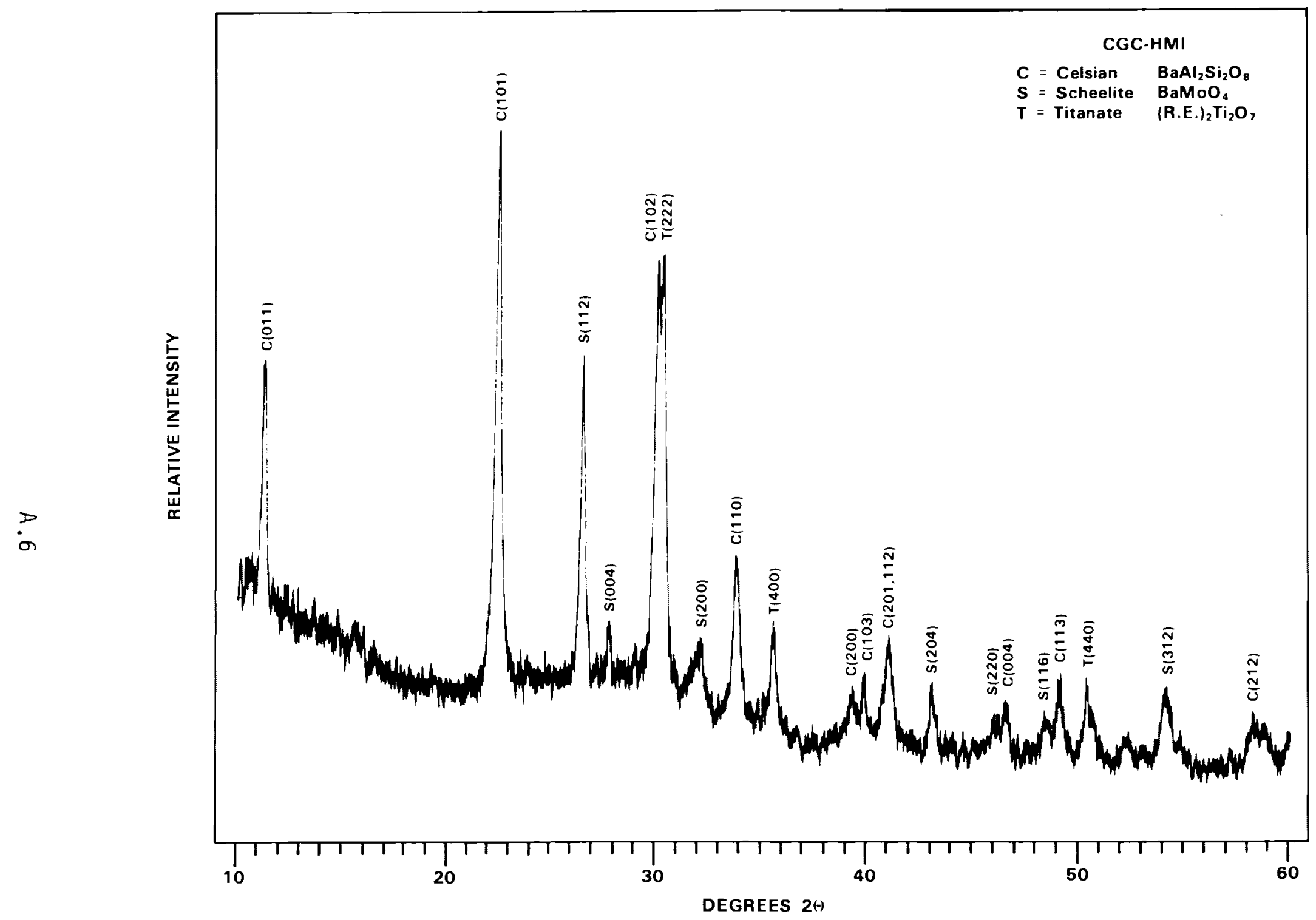

FIGURE A.6. X-Ray Diffraction Pattern of Ce1sian Glass Ceramic Containing 20 wt\% HMI Calcine 


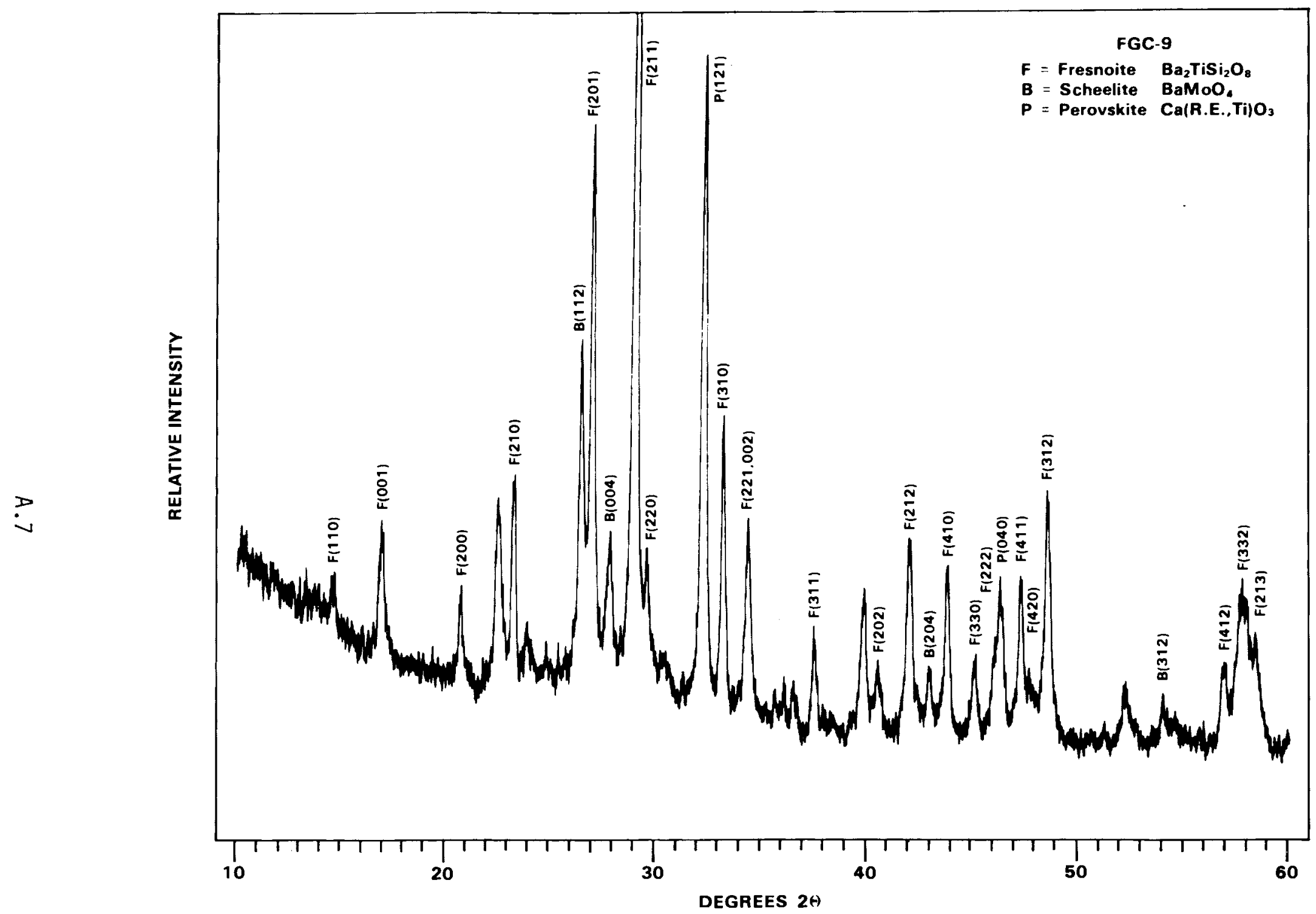

FIGURE A.7. X-Ray Diffraction Pattern of Fresnoite Glass Ceramic Containing 20 wt\% PW-9 Calcine 


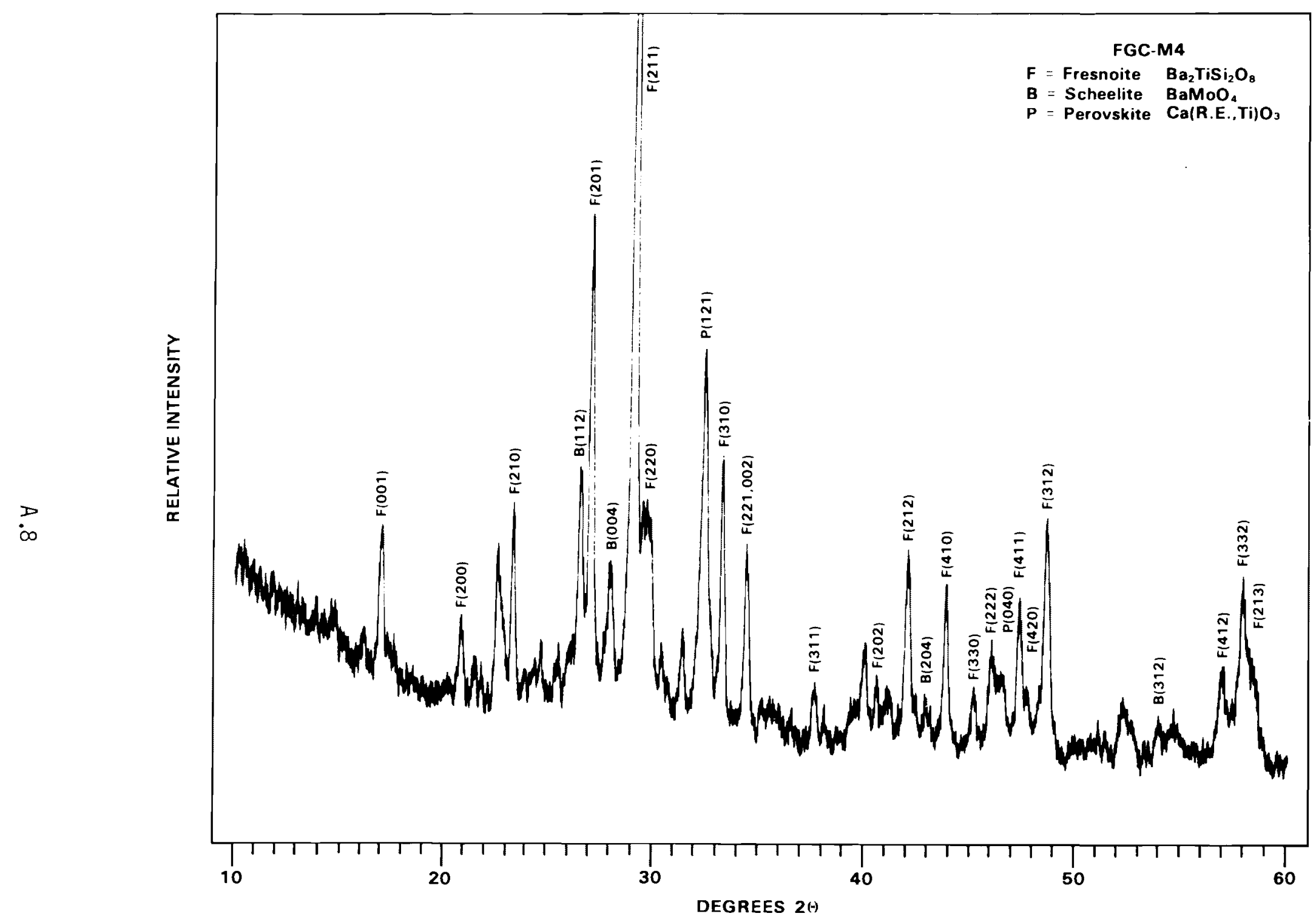

FIGURE A.8. X-Ray Diffraction Pattern of Fresnoite Glass Ceramic Containing 20 wt\% Modified PW-4b-7 Calcine 
APPENDIX B

NORMALIZED ELEMENTAL LOSSES OF MATERIALS LEACHED IN TEFLON AND POLYPROPYLENE 
TABLE B.1. Normalized Elemental Losses $\left(\mathrm{NL}_{j}\right)$ for $\mathrm{BGC}-4$ Leached at $90^{\circ} \mathrm{C}$ in Teflon Containers

\begin{tabular}{|c|c|c|c|c|c|c|c|c|c|c|}
\hline \multirow[b]{2}{*}{ Time, d } & \multicolumn{9}{|c|}{ Deionized Water at Leachant, $\mathrm{g} / \mathrm{m}^{2}$} & \multirow[b]{2}{*}{$\mathrm{pH}$} \\
\hline & $\bar{A} 1$ & $\mathrm{Ba}$ & $\mathrm{Ca}$ & $\mathrm{Mg}$ & Mo & $\mathrm{Na}$ & $\mathrm{Si}$ & Sr & $\mathrm{CS}$ & \\
\hline 3 & 0.39 & 1.18 & 0.14 & $-(a)$ & 0.53 & 0.97 & 0.43 & 0.55 & 0.47 & 7.81 \\
\hline 7 & 0.87 & 2.06 & 0.27 & 0.12 & 0.73 & 1.62 & 0.87 & 1.11 & 1.04 & 7.92 \\
\hline 14 & 1.37 & 2.63 & 0.30 & & 0.94 & 2.21 & 1.41 & 1.69 & & 8.36 \\
\hline 28 & 1.94 & 3.59 & 0.39 & 0.21 & 0.96 & 3.05 & 2.14 & 2.43 & 2.73 & 8.20 \\
\hline$\sigma(c)$ & +0.18 & \pm 0.11 & \pm 0.01 & \pm 0.02 & +0.07 & \pm 0.05 & +0.03 & \pm 0.14 & \pm 0.11 & \pm 0.13 \\
\hline
\end{tabular}

(a) Concentration in solution was below the detection limit.

(b) Not analyzed.

(c) $\sigma=$ one standard deviation from average of data of triplicate samples leached for 28 days.

TABLE B.2. Normalized Elemental Losses $\left(\mathrm{NL}_{i}\right)$ for CGC-HMI Leached at $90^{\circ} \mathrm{C}$ in Teflon Containers

\begin{tabular}{|c|c|c|c|c|c|c|c|c|c|c|}
\hline \multirow[b]{2}{*}{ Time, d } & \multicolumn{9}{|c|}{ Deionized water at Leachant, $\mathrm{g} / \mathrm{m}^{2}$} & \multirow[b]{2}{*}{$\mathrm{pH}$} \\
\hline & $\mathrm{B}$ & $\mathrm{Ba}$ & $\mathrm{Ca}$ & $\mathrm{Mg}$ & Mo & $\mathrm{Si}$ & $\mathrm{Sr}$ & $\mathrm{Cs}$ & $\mathrm{Li}$ & \\
\hline 3 & 10.20 & 3.45 & 7.32 & 4.93 & 15.35 & 5.66 & 8.98 & 17.36 & 11.11 & 9.36 \\
\hline 7 & 14.83 & 3.85 & 9.80 & 2.55 & 19.53 & 7.13 & 12.02 & 11.53 & 16.77 & 9.68 \\
\hline 14 & 18.26 & 3.76 & 11.51 & 2.98 & 22.68 & 7.72 & 13.73 & & 20.16 & 9.56 \\
\hline 28 & 22.57 & 3.82 & 12.78 & 2.69 & 27.40 & 8.65 & 15.83 & 22.36 & 26.40 & 9.52 \\
\hline$\sigma^{(b)}$ & \pm 0.70 & \pm 0.04 & \pm 0.36 & \pm 0.25 & +0.69 & \pm 0.00 & \pm 0.40 & \pm 0.55 & \pm 1.57 & \pm 0.02 \\
\hline
\end{tabular}

(a) Not analyzed.

(b) $\sigma=$ one standard deviation from average of data of triplicate samples leached for 28 days. 
TABLE B.3. Normalized Elemental Losses $\left(\mathrm{NL}_{j}\right)$ for 76-68 Glass Leached at $90^{\circ} \mathrm{C}$ in Polypropylene Containers

\begin{tabular}{|c|c|c|c|c|c|c|c|c|c|}
\hline \multirow[b]{2}{*}{ Time, $\mathrm{d}$} & \multicolumn{8}{|c|}{ Deionized Water at Leachant, $\mathrm{g} / \mathrm{m}^{2}$} & \multirow[b]{2}{*}{$\mathrm{pH}$} \\
\hline & $\bar{B}$ & $\mathrm{Ba}$ & $\mathrm{Ca}$ & Mo & $\mathrm{Na}$ & $\mathrm{Si}$ & $\mathrm{Sr}$ & $\mathrm{CS}$ & \\
\hline 3 & 3.41 & 3.38 & 3.43 & 3.90 & 2.98 & 3.40 & 3.65 & 6.82 & 9.37 \\
\hline 7 & 6.45 & 8.34 & 7.19 & 6.53 & 5.89 & 6.50 & 8.07 & 12.3 & 6.02 \\
\hline 14 & 8.40 & 12.75 & 10.2 .3 & 4.48 & 7.30 & 8.61 & 11.03 & & 4.72 \\
\hline 28 & 13.16 & 20.09 & 14.90 & 3.90 & 14.10 & 13.92 & 17.13 & 26.73 & 4.16 \\
\hline$\sigma^{(b}$ & +0.21 & +0.40 & +0.65 & +0.22 & +3.84 & +0.0 & +0.31 & +0.31 & +0.01 \\
\hline
\end{tabular}

(a) Not analyzed.

(b) $\sigma=$ one standard deviation from average of data of triplicate samples leached for 28 days. 


\section{ACKNOWLEDGMENT}

Appreciation is extended to K. R. Welsch for conducting the leach tests, N.T. Saenz for metallography, J. E. Coleman for SEM analysis, and J.W. Wald and R. P. May for x-ray diffraction analysis. The review and comments of R. P. Turcotte, J. M. Rusin, and D. M. Strachan are gratefully acknowledged. 



\section{DISTRIBUTION}

No. of

Copies

OFFSITE

A. A. Churm

DOE Chicago Patent Group

9800 South Cass Avenue

Argonne, IL 60439

27 DOE Technical Information Center

R. E. Cunningham

Office of Nuclear Safety Materials and Safeguards

Room 562

Nuclear Regulatory Commission

7915 Eastern Avenue

Silver Springs, MD 20910

3 Division of Waste Management

Nuclear Regulatory Commission

Mail Stop 905-SS

Washington, DC 20555

ATTN: J. B. Martin

D. M. Rohrer

R. D. Smith

W. E. Mott

DOE Division of Environmental

Control Technology

EV-13, GTN

Washington, DC 20545

13 DOE Office of Nuclear Waste

Management

Washington, DC 20545

ATTN: C. R. Cooley, NE-331, GTN

G. H. Daly, NE-322, GTN

J. D. Dieckhoner,

NE-321, GTN

C. H. George, NE-330, GTN

C. A. Heath, NE-330, GTN

M. L. Lawrence, NE-340, GTN

D. J. McGoff, NE-320, GTN

S. Meyers/R. Romatowski, NE-30, GTN

G. Oertel, NE-320, GTN

A. F. Perge, NE-30, GTN
No. of

Copies

R. W. Ramsey, Jr., NE-301, GTN

V. Trice, NE-30, GTN

D. L. Vieth, NE-332, GTN

S. A. Mann

DOE Chicago Operations and

Region office

Argonne, IL 60439

J. 0. Neff

DOE Col umbus Program Office

$505 \mathrm{King}$ Avenue

Columbus, $\mathrm{OH} 43201$

3 DOE Idaho Operations office

505 Second Street

Idaho Falls, ID 83401

ATTN: J. P. Hamric

J. W. Peel

J. B. Whitsett

3 Office of the Assistant

Manager for Energy Research

and Developinent

DOE Oak Ridge Operations

Office

P. 0. Box E

Oak Ridge, TN 37830

4 DOE Savannah River Operations Office

P. 0. Box A

Aiken, SC 29801

ATTN: E. S. Goldberg

T. B. Hindman

R. P. Whitfield

W. B. Wilson

DOE Albuquerque Operations Office

P. 0. Box 5400

Albuquerque, NM 97175

ATTN: R. Y. Lowrey (2)

A. L. Taboas 
No. of

Copies

10 Oak Ridge National Laboratory P.0. Box $Y$

Oak Ridge, TN 37830

ATTN: R. E. Blanco

J. 0. Blomeke

D. E. Ferguson

H. W. Godbee

E. H. Kobisk

W. J. Lackey

T. Lindemer

T. H. Row (3)

2 Central Research Library Document Reference Section Oak Ridge National Laboratory (DOE)

Oak Ridge, TN 37830

Los Alamos Scientific Laboratory P.0. Box 1663

Los Alamos, NM 87544

2 Exxon Nuclear I daho

P. 0. Box 2800

Idaho Fal1s, ID 83401

ATTN: D. L. Condotta

J. R. Berreth

4 EG G I daho

P.0. Box 1625

Idaho Falls, ID 83415

ATTN: A. L. Ayres

G. B. Levin

M. D. McCormack

W. C. Seymour

S. G. Harbinson

DOE San Francisco Operations

1333 Broadway

Oakland, CA 94612

2 Allied-General Nuclear Services

P. 0. Box 847

Barnwe 11, SC 29812

ATTN: J. A. Buckham

A. Williams
No. of

Copies

3 Argonne National Laboratory 9700 South Cass Avenue

Argonne, IL 60439

ATTN: J. H. Kittel

M. J. Steindler/

L. E. Trevorrow

J. L. Jardine

2 Brookhaven National Laboratory

Reference Section

Information Division

Upton, Long Island, NY 11973

6 Battelle Memorial Institute Office of Nuclear Waste I solation 505 King Avenue

Columbus, $\mathrm{OH} 43201$

ATTN: A. Brandstetter

W. Carbiener

N. E. Carter

P. L. Hofmann

M. Kehnemuyi

Beverly Rawles

Research Library

Battel le Memorial Institute

505 King Avenue

Col umbus, $\mathrm{OH} \quad 43201$

4 Rockwell International

Rocky Flats Plant

P.0. Box 464

Golden, CO 80401

ATTN: W. S. Bennett

Lawrence J. Smith

E. Vejvoda

M. A. Thompson

2 A. B. Martin Rockwell International 8900 DeSoto Avenue

Canoga Park, CA 91304

5 E. I. du Pont de Nemours Co. Savannah River Laboratory

Aiken, SC 29801

ATTN: M. D. Boersma

R. G. Garvin

D. L. McIntosh

M. S. Plodinec

R. Maher 
No. of

Copies

R. Williams

Electric Power Research Institute $3412 \mathrm{Hillview}$ Avenue

P.0. Box 10412

Palo Alto, CA 94304

2 Environmental Protection Agency

Technological Assessment Division (AW-559)

Office of Radiation Programs

U.S. Environmental Protection Agency

Washington, DC 20460

J. P. Duckworth

Plant Manager

Nuclear Fuels Services, Inc.

P.0. Box 124

West Valley, NY 14171

4 Lawrence Livermore Laboratory

P.0. Box 808

Livermore, CA 94550

ATTN: J. Campbel1 (3)

J. D. Tewhey

2 Sandia Laboratories

Albuquerque, NM 87185

ATTN: R. G. Kepler

J. K. Johnstone

R. G. Post

College of Engineering

University of Arizona

Tucson, AZ 85721

L. L. Hench

Dept. of Materials Science and

Engineering

University of Florida

Gainesville, FL 32611

H. Palmour, III

2140 Burlington Engineering Laboratories

North Carolina State University

Raleigh, NC 27607

R. Roy

202 Materials Research Laboratory

University Park, PA 16802
No. of

Copies

D. E. Harrison

Westinghouse Electric Corporation

P. 0. Box 355

Pittsburg, PA 15230

J. G. Cline, General Manager

NYS Atomic and Space Development Authority

230 Park Avenue, Rm. 2425

New York, NY 10017

John Pomeroy

Technical Secretary

National Academy of Sciences

Committee of Radioactive Waste

Management

National Research Council

2101 Constitution Avenue

Washington, DC 20418

L. Henning

Electric Power Research Institute 3412 Hillview Avenue

P.0. Box 10412

Palo Alto, CA 94304

G. J. McCarthy

Department of Chemistry

North Dakota State University

Fargo, ND 58102

Rod Ewing

University of New Mexico

Albuquerque, NM 87131

B. Adams

Corning Glass Works

Technical Staffs Division

Corning, NY 14830

ONSITE

4 DOE Richland Operations Office

E. A. Bracken

P. A. Craig

J. J. Schreiber

H.E. Ramsom 
No. of

Copies

16 Rockwell Hanford Operations

H. Babad

L. C. Brown

R. A. Deju

R. J. Gimera

D. R. Gustavson

E. J. Kosiancic

M. J. Kupfer

C. M. Manry

I. E. Reep

J. H. Roecher

W. W. Schulz

M. J. Smith

D. D. Wodrich (3)

File Copy

3 UNC United Nuclear Industries

F. H. Bouse, Document Control

T. E. Dabrowski

A. E. Engler

Westinghouse Hanford Company

A. G. Blasewitz

59 Pacific Northwest Laboratory

S. M. Barnes

W. J. Bjorklund

H. T. Blair

W. F. Bonner

D. J. Bradley

D. W. Brite

C. Q. Buckwalter

J. L. Buelt

L. R. Bunnell

J. G. Carter

L. A. Chick

T. D. Chikalla

G. J. Exarhos

W. J. Gray

W. E. Gurwel 1

A. J. Haverfield/W. R. Wiley

L. K. Holton

J. H. Jarrett

Y. B. Katayama

R. S. Kemper
No. of

Copies

D. E. Knowl ton

C. A. Knox

L. T. Lakey

D. E. Larson

R. 0. Lokken (5)

J. L. McEl roy

G. L. McVay

G. B. Mellinger

J. E. Mendel

R. D. Nelson

J. F. Nesbitt

R. E. Nightingale

A. M. Platt

W. A. Ross

J. M. Rusin

M. J. Schl iebe

R. J. Serne

J. W. Shade

D. H. Siemens

S. C. Slate

D. M. Strachan

C. L. Timmerman

R. L. Treat

R. P. Turcotte (2)

J. W. Wald

W. J. Weber

J. H. Westsik, Jr.

Technical Information (5)

Publishing Coordination (2) 